\title{
IDENTIFICAÇÃO E CARACTERIZAÇÃO DE SEQÜÊNCIAS EXPRESSAS (EST) NA MUSCULATURA PEITORAL DE FRANGOS DE CORTE
}

\author{
Helena JaViel AlVes
}

Tese apresentada à Escola Superior de Agricultura "Luiz de Queiroz", Universidade de São Paulo, para obtenção do título de Doutor em Agronomia, Área de concentração: Ciência Animal e Pastagens

PIR A C I C A B A

Estado de São Paulo - Brasil

Setembro - 2004 


\title{
IDENTIFICAÇÃO E CARACTERIZAÇÃO DE SEQÜÊNCIAS EXPRESSAS (EST) NA MUSCULATURA PEITORAL DE FRANGOS DE CORTE
}

\author{
Helena Javiel Alves
}

Médica Veterinária

Orientador: Prof. Dr. LUIZ LEHMANN COUTINHO

Tese apresentada à Escola Superior de Agricultura "Luiz de Queiroz", Universidade de São Paulo, para obtenção do título de Doutor em Agronomia, Área de concentração: Ciência Animal e Pastagens

P I R A C I C A B A

Estado de São Paulo - Brasil

Setembro - 2004 

Dados Internacionais de Catalogação na Publicação (CIP)
DIVISÃO DE BIBLIOTECA E DOCUMENTAÇÃO - ESALQ/USP

Alves, Helena Javiel

Identificação e caracterização de seqüências expressas (EST) na musculatura peitoral de frangos de corte / Helena Javiel Alves. - - Piracicaba, 2004. 103 p. : il.

Tese (Doutorado) - - Escola Superior de Agricultura Luiz de Queiroz, 2004. Bibliografia.

1. Biologia animal 2. Desenvolvimento animal 3. Expressão gênica 4. Frangos de corte 5. Linhagem animal 6. Melhoramento genético animal I. Título

CDD 636.513

"Permitida a cópia total ou parcial deste documento, desde que citada a fonte - O autor" 


\section{AGRADECIMENTOS}

À Deus, acima de tudo.

Ao Prof. Dr. Luiz Lehmann Coutinho, agradeço pela oportunidade, orientação e pelos valiosos ensinamentos.

À FAPESP pelo apoio financeiro ao desenvolvimento deste trabalho.

Aos professores do Departamento de Produção Animal pelos ensinamentos adquiridos.

Às secretárias do Departamento de Produção Animal pelo atendimento e atenção recebidos.

Ao funcionário Alexandre do Departamento de Produção Animal, pela ajuda nos experimentos.

Ao Dr. André Vettore, Dra. Otavia Caballero e à Márcia pela ajuda recebida.

À Dra. Cláudia Barros Monteiro Vitorello pela grande ajuda, apoio e amizade.

Ao Centro Nacional de Pesquisa de Suínos e Aves (CNPSA-EMBRAPA) pela valiosa colaboração.

À Dra. Mônica Correa Ledur pelo apoio e amizade.

Ao amigo Marcelo de Lima Marchesin pela valiosa ajuda em todas as etapas deste trabalho.

Às amigas Érika, Clarissa, Rachel e Gisele pela ajuda na realização deste trabalho.

Aos meus pais e irmãos, pelo carinho, incentivo e apoio sempre recebidos.

Ao Junior, pelo apoio, carinho e incentivo em todos os momentos.

Ao pessoal do Laboratório de Biotecnologia pela amizade e convivência.

À todos aqueles que de alguma maneira contribuíram para a realização deste trabalho. 


\section{SUMÁRIO}

Página

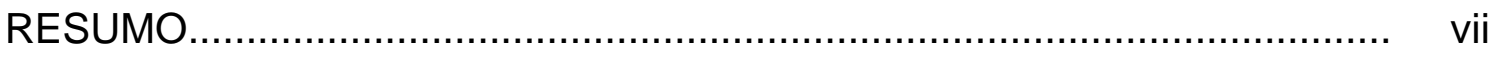

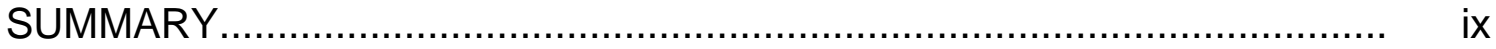

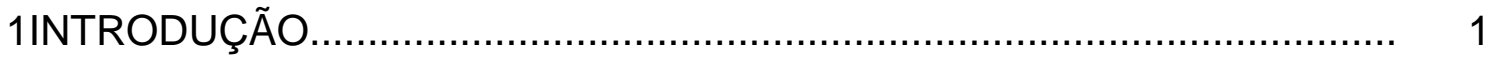

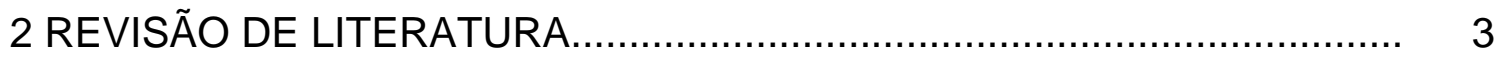

2.1 Origem embrionária da musculatura esquelética............................ 3

2.20 programa miogênico....................................................... 6

2.2.1 Regulação positiva da miogênese ............................................ 7

2.2.2 Regulação negativa da miogênese........................................ 8

2.2.3 Expressão dos MRFs, Pax-3 e miostatina no músculo adulto de aves 9

2.3 A maturação da fibra muscular................................................. 10

2.3.1 Tipos de fibras musculares................................................. 13

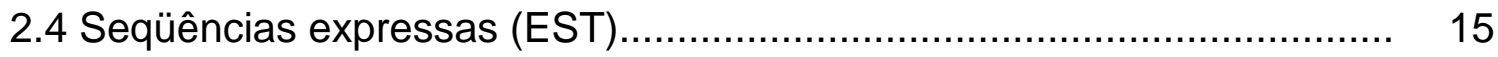

2.5 Single Nucleotide Polymorphisms (SNPs) .......................... 17

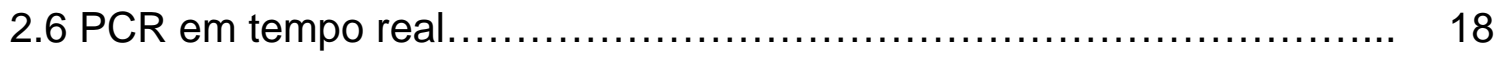

3 MATERIAL E MÉTODOS........................................................... 24

3.1 Incubação dos ovos e coleta dos tecidos.................................... 24

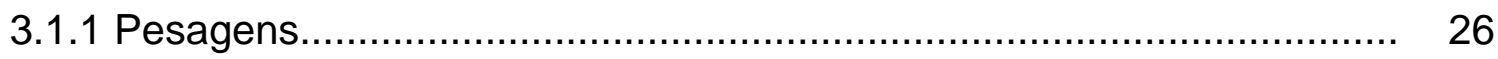

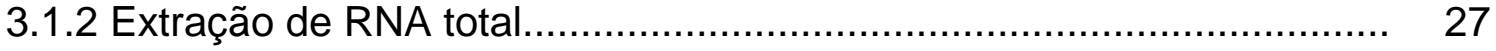

3.1.3 Isolamento do RNA mensageiro.......................................... 27

3.1.4 Construção das bibliotecas de cDNA ..................................... 28

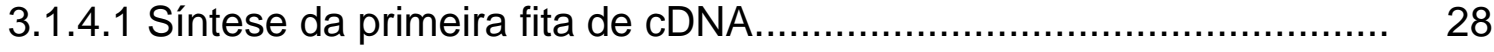

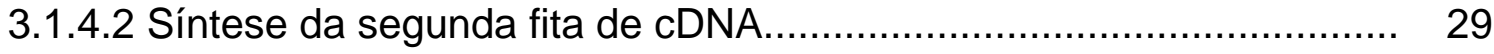


Página

3.1.4.3 Adição do adaptador Sal I....................................................... 30

3.1.4.4 Digestão com Not I.................................................................. 30

3.1.4.5 Fracionamento do cDNA ............................................................... 32

3.1.4.6 Ligação ao vetor pSPORT 1................................................. 32

3.2 Preparação das células competentes e transformação por choque térmico.

3.3 Mini-preparação do DNA plasmidial................................................ 34

3.4 PCR da mini-preparação............................................................... 35

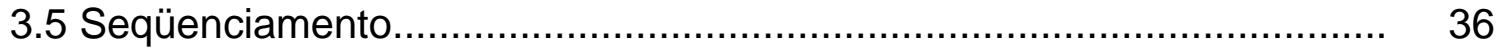

3.6 Purificação da reação de seqüenciamento ........................................ 36

3.7 Análise das seqüências ............................................................. 37

3.7.1 Análise de qualidade de seqüências $($ Phred) .................................. 38

3.7.2 Clusterização(Сap3).............................................................. 38

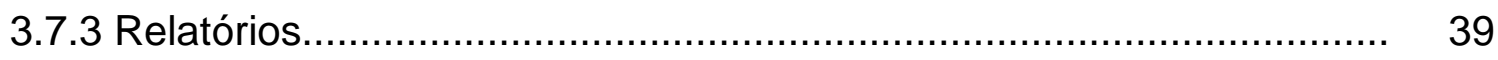

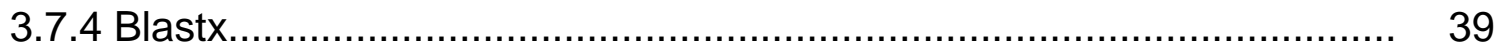

3.7.5 Categorização das seqüências …............................................. 40

3.8 Análise de expressão gênica......................................................... 41

3.8.1 Incubação dos ovos e coleta dos tecidos......................................... 42

3.8.2 Extração de RNA total e síntese de cDNA........................................ 43

3.8.3 PCR em tempo real................................................................ 43

4 RESULTADOS E DISCUSSÃO............................................................ 46

4.1 Parâmetros de peso................................................................... 46

4.2 Extração de RNA total e seleção do RNA mensageiro........................... 47

4.3 Construção da biblioteca de cDNA ................................................... 48

4.4 Avaliação de tamanho dos insertos clonados...................................... 48

4.4.1 Análise das ESTs.................................................................. 49

4.4.2 Categorização das ESTs......................................................... 54

4.4.2.1 Análise das sequências No hits................................................. 55

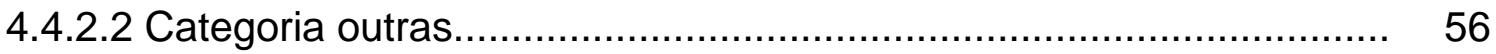


Página

4.4.2.3 Proteínas musculares............................................................ 58

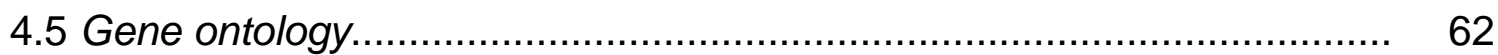

4.6 Análise de polimorfismo............................................................. 66

4.7 Análise das ESTs biblioteca-específicas.......................................... 68

4.8 Análise de expressão gênica......................................................... 70

4.8.1 Extração de RNA total................................................................. 70

4.8.2 PCR em tempo real............................................................. 71

4.8.3 Análise de expressão dos fatores miogênicos: MyoD, MRF4 e miogenina; Pax-3 e miostatina........................................................ $\quad 72$

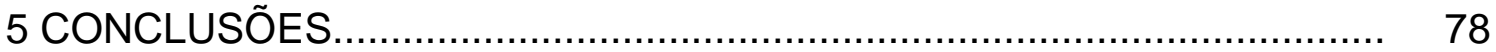

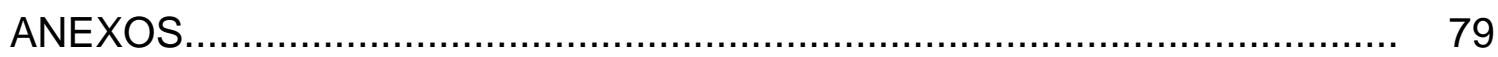

REFERÊNCIAS BIBLIOGRÁFICAS................................................. 92 


\title{
IDENTIFICAÇÃO E CARACTERIZAÇÃO DE SEQÜÊNCIAS EXPRESSAS (EST) NA MUSCULATURA PEITORAL DE FRANGOS DE CORTE
}

\author{
Autora: HELENA JAVIEL ALVES \\ Orientador: Prof. Dr. LUIZ LEHMANN COUTINHO
}

\section{RESUMO}

A produção de aves no Brasil vem crescendo na ordem de $10 \%$ a cada ano, o que se explica pela atualização constante da tecnologia do setor (http://www.abef.com.br). Sendo a carne de frango a fonte de proteína animal mais barata e acessível ao consumidor, há necessidade de se produzir cada vez mais animais com maior acúmulo de massa muscular. Para isso, o entendimento dos mecanismos celulares e moleculares envolvidos na formação da musculatura esquelética é de extrema relevância. Os fatores miogênicos, genes responsáveis pela determinação e diferenciação de células musculares, foram clonados e progressos significativos foram desenvolvidos quanto ao controle da expressão dos mesmos. A utilização da técnica de seqüenciamento de DNA possibilita a identificação e caracterização de novos genes envolvidos na complexa rede de fatores que regulam a formação da musculatura esquelética em aves. Neste estudo, foram construídas duas bibliotecas de cDNA (fase embrionária e pós-eclosão) de músculo peitoral de uma linhagem de corte (TT) e uma biblioteca da fase embrionária de uma linhagem de postura (CC). A análise das seqüências EST (Expressed Sequence Tags) foi utilizada 
para identificar possíveis novos genes envolvidos no processo de formação da musculatura esquelética. As seqüências EST identificadas possibilitaram a construção de um banco com 6247 ESTs da musculatura peitoral das linhagens de corte e postura nas duas fases de desenvolvimento. Com o intuito de estabelecer uma relação entre o perfil de expressão dos fatores miogênicos: MyoD, MRF4 e miogenina; e dos genes Pax-3 e miostatina e a formação e maturação das fibras musculares, foi utilizada a técnica de PCR em tempo real. Em geral, a expressão dos fatores miogênicos foi maior na linhagem de corte em relação à de postura nas idades estudadas. Este estudo deverá contribuir para as áreas celular e molecular de desenvolvimento, além de fornecer recursos úteis aos programas de melhoramento genético de aves que visam obter animais com maior acúmulo de massa muscular. 


\title{
IDENTIFICATION AND CHARACTERIZATION OF EXPRESSED SEQUENCE TAGS (EST) IN BROILER'S BREAST MUSCLE
}

\author{
Author: HELENA JAVIEL ALVES \\ Adviser: Prof. Dr. LUIZ LEHMANN COUTINHO
}

\section{SUMMARY}

Brazilian's chicken production is increasing annually around $10 \%$, which can be explained by the current technology applied to this sector (http://www.abef.com.br). Being chicken's meat the cheapest animal protein source for consumers, there is a need to produce even more animals with increased muscular mass. For this purpose, understanding the molecular and cellular mechanisms involved with the skeletal muscle development is of great relevance. The myogenic factors, genes responsible for the determination and differentiation of muscle cells, were cloned and significant progress was made on the control of their expression. The use of DNA sequencing technique allows the identification and characterization of new genes involved in the complex chain of factors signalling systems that regulates the expression of avian skeletal muscles. In this study, two cDNA libraries (embryonic and post-hatching phases) were constructed from the breast muscle of a chicken broiler line (TT) and one library, from the embryonic phase, from a chicken layer line (CC). The EST (Expressed Sequencing Tags) analysis was used to identify probable new genes involved in the skeletal muscle development. The identified ESTs were used to generate a database containing 6247 breast muscle ESTs from two 
chicken lines in two development phases. Real time PCR was employed with the aim of establishing a relationship among the expression profile of myogenic factors (MyoD, MFR4, and myogenin), Pax-3 and myostatin genes with the formation and maturation of muscle fibers. In general, the expression of myogenic factors was greater in the broiler than in the layer chicken line in the phases under study. These results should contribute to other cellular and molecular development studies besides providing useful resources for chicken breeding programs whose objective is the deposition of skeletal muscle mass. 


\section{INTRODUÇÃO}

A avicultura é uma das atividades que mais tem se destacado nos últimos anos. A produção de aves no Brasil vem crescendo na ordem de $10 \%$ a cada ano, resultado da constante atualização tecnológica do setor. Além disso, a produção de carne de frango em 2003 foi em torno de 7,8 milhões de toneladas, situando o país em posição de destaque no cenário internacional do setor, sendo o segundo maior produtor e o terceiro maior exportador. Com o aumento na produtividade, a carne de frango tornou-se a proteína animal mais barata e acessível ao consumidor brasileiro. Dentro deste contexto, estudos que envolvam seqüenciamento de Expression Sequence Tags (ESTs) de músculo peitoral de frangos de corte são de extrema importância para o avanço nas pesquisas em avicultura.

A análise da expressão dos fatores trans-regulatórios envolvidos no desenvolvimento da musculatura esquelética em aves é uma linha de pesquisa que vem sendo bastante estudada. Há uma complexa rede de fatores que controlam a miogênese. Tais fatores atuam no controle da atividade de genes que codificam proteínas musculares, bem como daqueles que regulam negativamente o processo, permitindo que as etapas de determinação e diferenciação das células do tecido muscular esquelético sejam ativadas no local e momento apropriados (Ludolph \& Konieczny, 1995). Recentemente McPherron et al., 1997 identificaram um novo membro da família TGF- $\beta$ (Transforming Growth Factor- $\beta$ ), o GDF-8 (Growth/Differentiation Factor-8), também conhecido como miostatina, que é expresso no desenvolvimento embrionário e no músculo esquelético adulto e que se acredita funcionar como 
um regulador negativo do desenvolvimento da musculatura esquelética. Inúmeros outros genes devem estar atuando nessa complexa rede molecular e podem, através da utilização das técnicas de seqüenciamento de DNA, ser identificados e analisados.

As seqüências EST (Expression Sequence Tags) têm provado ser um eficiente método para se obter dados preliminares de uma biblioteca de cDNAs. Há informação suficiente nas 200-400 bases de nucleotídeos seqüenciados das extremidades dos fragmentos de cDNA para a identificação preliminar de cDNAs e a localização dessas seqüências nos cromossomos (Adams et al., 1991). Uma vez que as bibliotecas de cDNA são sintetizadas a partir do RNA mensageiro, a análise das seqüências EST permite estabelecer a coleção dos genes que são expressos em um determinado tecido. Elas também indicam o nível de atividade dos diferentes genes no tecido e permitem fazer comparações entre diferentes tecidos e diferentes estádios de desenvolvimento. Além disso, torna-se possível a obtenção de informações essenciais sobre a função dos genes e a fisiologia do tecido (Okubo et al., 1992). Outra potencialidade de um projeto EST é permitir a localização de novos polimorfismos em regiões de interesse do genoma, aumentando o número de genes candidatos para estudos de QTL (Quantitative Trait Loci) (Hatey et al., 1998).

Nesse contexto, o objetivo do presente estudo foi analisar 6000 ESTs de três bibliotecas de clones de cDNA obtidas a partir do músculo peitoral de duas linhagens de aves (corte e postura) em diferentes estádios de desenvolvimento, no intuito de determinar os diferentes genes que são expressos neste tecido. Os resultados obtidos possibilitaram a comparação do nível de atividade dos diferentes genes na musculatura peitoral de frangos de corte. Além disso, foram realizados estudos de expressão de cinco genes relacionados ao processo de formação da musculatura esquelética em aves. Portanto, o presente estudo contribuiu positivamente para o entendimento dos mecanismos envolvidos na miogênese em aves. 


\section{REVISÃO DE LITERATURA}

\subsection{Origem embrionária da musculatura esquelética}

Os mecanismos moleculares que levam a formação de fibras musculares funcionais e os fatores envolvidos na determinação e comprometimento de células precursoras têm sido objeto de estudo por décadas (Brand-Saberi \& Christ, 1999). O desenvolvimento da musculatura esquelética é determinado por um conjunto de alterações moleculares, celulares e morfológicas que se tornaram modelo para a compreensão da complexa rede molecular que atua desde a determinação da linhagem de células musculares dentro do conjunto de células embrionárias até a completa maturação da fibra muscular (Ludolph \& Konieczny, 1995).

As fibras musculares são provenientes de células precursoras miogênicas chamadas mioblastos que se proliferam, fundem-se para formar os miotubos e finalmente se diferenciam em fibras musculares. Em vertebrados, os mioblastos se originam nos somitos, que são estruturas segmentadas de mesoderma paraxial dispostas paralelamente ao tubo neural e notocorda do embrião (Christ \& Ordahl, 1995; Rawls \& Olson,1997, Stockdale et al., 2000; Picard et al., 2002; Wigmore \& Evans, 2002). Os somitos originam-se por segmentação seqüencial do mesoderma paraxial formando pares de esferas epiteliais de cada lado do tubo neural (Figura 1). 


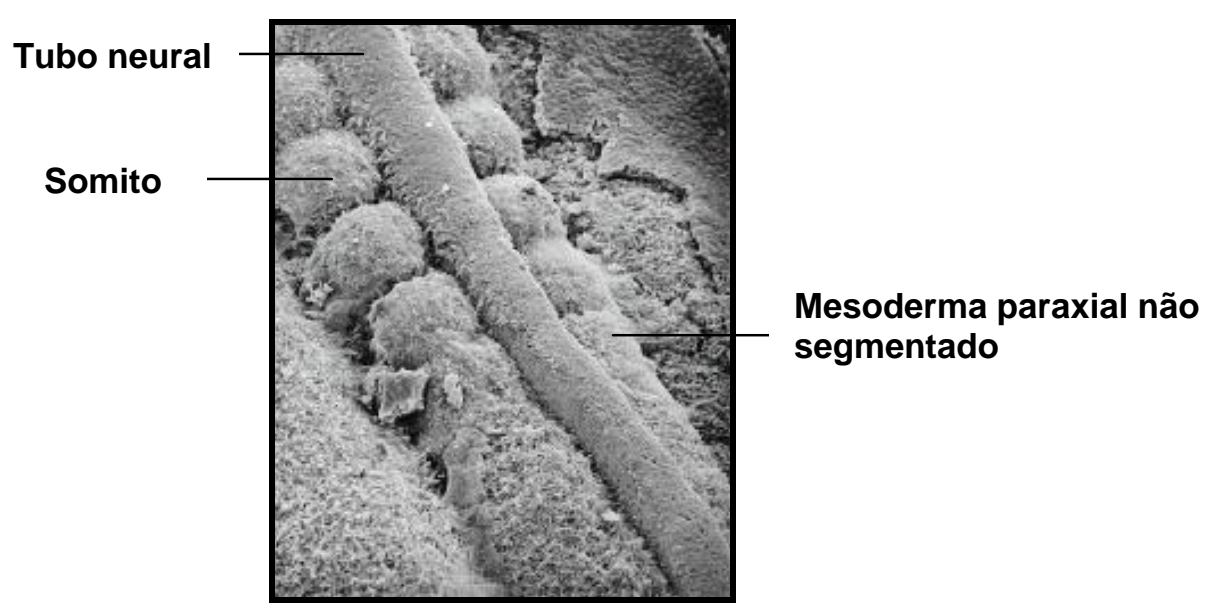

Figura 1 - Micrografia eletrônica de varredura ilustrando estruturas embrionárias

Fonte: Gilbert, 2003.

Em uma etapa subseqüente do desenvolvimento embrionário, em resposta a sinais vindos das estruturas adjacentes (tubo neural e notocorda), os somitos compartimentalizam-se em três domínios celulares distintos: o esclerótomo, o miótomo e o dermomiótomo. Inicialmente, a região ventral do somito forma o esclerótomo, do qual as costelas e vértebras são derivadas. A região dorsal forma uma camada epitelial conhecida como dermomiótomo, que contém células precursoras de músculo esquelético e derme.

Os limites dorsomedial e ventrolateral do dermomiótomo, denominados de lábio dorsomedial e lábio ventrolateral se curvam lateralmente sobre o esclerótomo. A partir destes limites as células irão derivar para a formação do miótomo, camada de células que se situa entre o dermomiótomo e o esclerótomo. Antes da formação do miótomo, entretanto, o dermomiótomo torna-se dividido em duas partes, medial e lateral. As células do dermomiótomo medial dão origem aos músculos das costas e musculatura intercostal (musculatura epaxial), enquanto que as células da porção lateral originam os músculos da parede ventral do corpo, dos membros, diafragma e pescoço (musculatura hipaxial) (Ordahl \& LeDouarin, 1992; Rawls \& Olson, 1997; Maroto 
et al., 1997; Tajbakhsh et al., 1997; Wigmore \& Evans, 2002). Já os músculos da região cefálica são derivados do mesoderma paraxial anterior não segmentado e do mesoderma pré cordal (Picard et al, 2002; Buckingham et al, 2003). Na Figura 2 está representada a maturação dos somitos durante a miogênese.

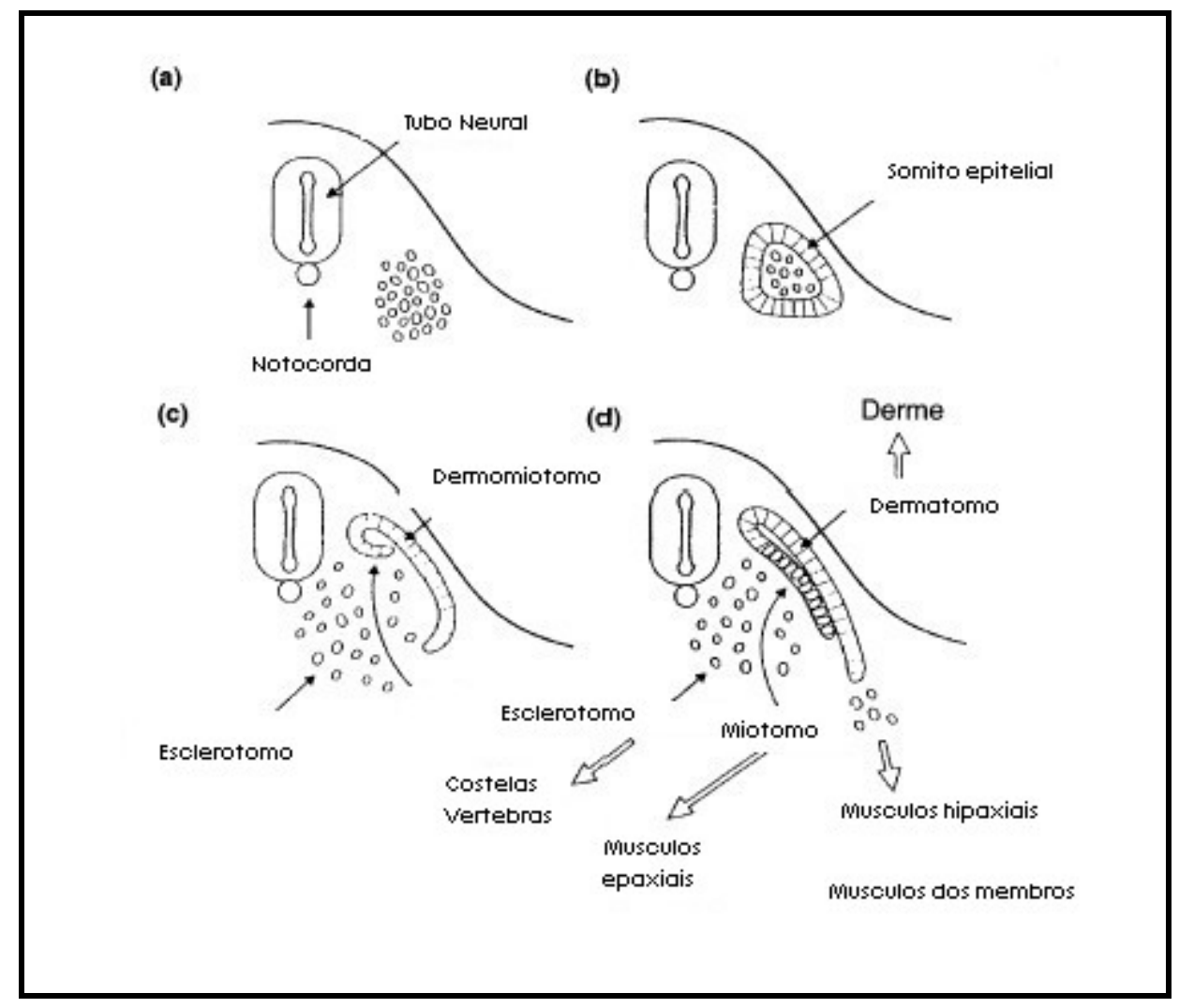

Figura 2 - Maturação do somito durante a miogênese em vertebrados. (a) formação do somito. (b) Estrutura de um somito epitelial. (c) Diferenciação do somito. (e) Diferenciação do dermátomo, miótomo e esclerótomo

Fonte: adaptado de Picard et al. (2002) 


\subsection{0 programa miogênico}

A miogênese é um processo que envolve a determinação dos precursores miogênicos nos tecidos embrionários, a proliferação celular e a diferenciação e maturação da fibra muscular. Portanto, deve haver uma rede complexa de fatores modulando estes eventos, de maneira que a transcrição espacial e temporal de genes músculo-específicos ocorra ordenadamente (revisado por Arnold \& Winter, 1998; Arnold \& Braun, 2000).

Os fatores regulatórios miogênicos (Myogenic Regulatory Factors MRFs) são parte de uma superfamília de fatores de transcrição basic helix-loophelix (bHLH). As proteínas MRF contêm um domínio básico de ligação ao DNA conservado que é essencial para a ligação seqüência-específica ao DNA. Além disso, possuem um motivo HLH (hélice-volta-hélice) necessário para a heterodimerização. Cada uma das MRFs é capaz de heterodimerizar com proteínas E e se ligar ao DNA de uma maneira seqüência-específica a sítios conhecidos como E-boxes (CANNTG), presentes nos promotores de muitos genes músculo-esquelético específicos (Rudnicki \& Jaenisch, 1995; Sabourin \& Rudnicki, 2000).

A superfamília MyoD é composta por: MyoD, Myf-5, miogenina e MRF4.

O fator MyoD foi o primeiro a ser identificado, em virtude de sua habilidade de converter fibroblastos em células miogênicas (Davis et al., 1987; Weintraub et al., 1991; Rudnicki \& Jaenisch, 1995; Sabourin \& Rudnicki, 2000). Subseqüentemente, os outros fatores foram identificados. Estes quatro fatores de transcrição estão relacionados com a ativação do programa miogênico. Sendo que MyoD e Myf-5, denominados MRFs primários, são necessários para a etapa de determinação, onde ocorre o comprometimento das células proliferativas dos somitos com a linhagem miogênica. As células comprometidas (mioblastos) podem proliferar e mais adiante, diferenciar em miócitos e amadurececer em miofibras sob a ação dos MRFs secundários, miogenina e MRF4 (Figura 3) (Emerson, 1993; Arnold \& Braun, 2000; Puri \& 
Sartorelli, 2000; Sabourin \& Rudnicki, 2000). Em aves, o primeiro gene a ser ativado é o MyoD, seguido por Myf-5 e miogenina (Coutinho et al., 1993). Análises de hibridação in situ demonstraram que o fator miogênico MyoD desempenha papel importante na manutenção da miogênese (Gabriel et al., 2000). Em estudo recente foi sugerido que os níveis de Myf-5 em animais onde foi bloqueada a expressão dos outros três fatores (MyoD, MRF4 e miogenina), são insuficientes para ativar o programa miogênico (Valdez et al., 2000).

\subsubsection{Regulação positiva da miogênese}

Várias proteínas têm sido identificadas na regulação positiva da miogênese. Entre elas, Myocyte Enhancer Factor 2 (MEF2) e proteínas não miogênicas E2A, que formam heterodímeros com os fatores miogênicos, promovendo a sua ligação ao DNA (Rudnicki \& Jaenisch, 1995; Black \& Olson, 1998; Puri \& Sartorelli, 2000). Fatores de transcrição gerais como SerumResponse-Factor (SRF) que se liga à seqüência consenso CArG-box encontrada na maioria das regiões regulatórias do músculo, freqüentemente em justaposição com E-box (Puri \& Sartorelli, 2000; Sabourin \& Rudnicki, 2000).

Em adição, Pax-3, um fator de transcrição caracterizado pela presença de motivos com domínios homeo e paired, tem sido identificado como um importante regulador da miogênese, podendo ativar a expressão de MyoD, Myf5 e miogenina (Maroto et al., 1997; Arnold \& Winter, 1998). A proteína LIM parece estar relacionada à diferenciação celular (Arber et al.,1994; Ludolph \& Konieczny, 1995; Kong et al., 1997).

Ainda em relação à regulação positiva da miogênese, sinais vindos das estruturas axias (tubo neural e notocorda) como Sonic hedgehog (Shh) e Wnt induzem a miogênese (Bailey et al., 2001). 


\subsubsection{Regulação negativa da miogênese}

Dentre os reguladores negativos do programa miogênico estão os fatores de crescimento Fibroblast Growth Factor (FGF) e Transforming Growth Factor- $\beta$ (TGF- $\beta$ ), descritos como potentes inibidores de diferenciação (Emerson, 1993; Dauncey \& Gilmour, 1996). Os MRFs podem também ser regulados negativamente por proteínas Id (Inhibidor of differentiation). Estas, agem de maneira dominante por heterodimerização com proteínas E, impedindo sua associação com os MRFs e, conseqüentemente, a ativação de genes músculoespecíficos (Sasson et al., 1993). Mais recentemente foram identificadas outras proteínas reguladoras do programa miogênico como Notch, Mist1, Twist, entre outras, que atuam regulando negativamente as etapas da miogênese, desde a determinação dos precursores até a maturação final da fibra muscular. Para tanto, Notch atua impedindo o processo de diferenciação miogênica e Mist 1 juntamente com MyoR são repressoras da miogênese. A proteína Twist, da mesma forma que Id pode reprimir a transcrição de genes musculares por seqüestrar proteínas E (revisado por Füchtbauer, 2002; Puri \& Sartorelli, 2000; Sabourin \& Rudnicki, 2000). McPherron et al. (1997) identificaram um novo membro da família TGF- $\beta$, Growth and Differentiation Factor 8 (GDF-8), também conhecido como miostatina, que é expresso durante o desenvolvimento embrionário e no músculo esquelético adulto e cujo produto funciona como um regulador negativo do desenvolvimento da musculatura esquelética. Inúmeros outros genes devem estar atuando nessa rede molecular complexa e podem através da utilização das técnicas de seqüenciamento de DNA, ser identificados e analisados. De fato, a formação correta da musculatura esquelética, em espaço e tempo, pode ser resultado de uma interação complexa de sinais positivos e negativos (Arnold \& Braun, 2000). Na Figura 3 estão representados alguns fatores que atuam na regulação da miogênese em aves. 


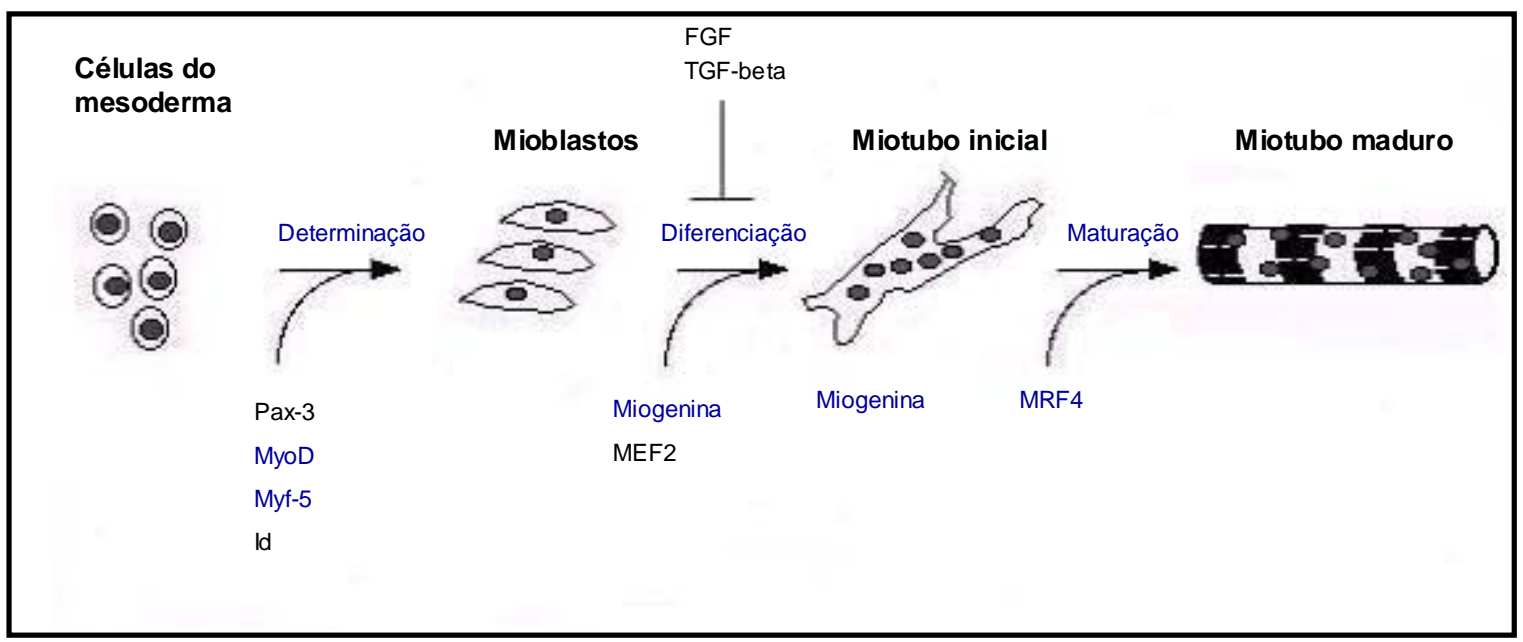

Figura 3 - Regulação da miogênese

Fonte: adaptado de Ludolph \& Konieczny, 1995

\subsubsection{Expressão dos MRFs, Pax-3 e Miostatina no músculo adulto de aves}

Os fatores regulatórios miogênicos estão também presentes durante a formação das fibras musculares adultas (Buckingham et al., 2003). Porém, existem poucas informações sobre o perfil de expressão destes fatores na fase final do período embrionário, bem como na fase pós-eclosão em aves.

Análises de expressão dos MRFs no músculo peitoral de embriões "tardios" (fase final do desenvolvimento embrionário) e aves adultas indicaram que os RNA mensageiros de MyoD e MRF4 estão presentes em altos níveis em todos os estádios de desenvolvimento, bem como em adultos. A expressão de miogenina aumenta entre os dias E8 e E10, após os quais decresce até o dia E17, estando presente em baixos níveis em adultos. O fator miogênico Myf-5 permanece em um nível mais ou menos constante até o segundo dia após a eclosão e então decresce até o sétimo dia, sendo indetectável em adultos (Cheng et al., 1992). 
O fator de transcrição Pax-3, além de ser descrito como um importante regulador da miogênese (nas fases iniciais de formação do músculo), também desempenha papel crucial na formação do músculo esquelético adulto. (Buckingham, 2001).

A expressão de miostatina tem sido descrita desde os primeiros estádios embrionários. Análises de RT-PCR relataram que a expressão do gene da miostatina foi primeiramente detectada durante o estádio de blastoderma (embrião não incubado) e permaneceu constante até o estádio E1. Após isso, houve um declínio na expressão de miostatina que permaneceu baixo até o estádio E6. Já no estádio E7 os níveis aumentaram até atingir um pico de expressão no estádio E16 que se manteve alto até o estádio E19, diminuindo antes da eclosão (Kocamis et al., 1999). Resultados semelhantes foram obtidos por Scheuermann et al. (2004) comparando a expressão de miostatina em aves de corte e postura entre os estádios E1 e E20 do desenvolvimento embrionário. Guernec et al. (2003) utilizaram a metodologia de RT-PCR em tempo real para verificar a relação da expressão de miostatina com o desenvolvimento das fibras musculares no músculo peitoral em duas linhagens: uma selecionada para alto rendimento de carne de peito e outra utilizada como controle. Os níveis de expressão de miostatina foram maiores durante o período embrionário de desenvolvimento, diminuíram ao redor da eclosão e aumentaram com duas semanas de idade.

\subsection{A maturação da fibra muscular}

O processo de formação da fibra muscular envolve a proliferação dos mioblastos (células precursoras de músculo) em seguida estes mioblastos se fundem para a formação dos miotubos e, finalmente, ocorre a diferenciação em fibras musculares (Picard et al., 2002). 
Em animais de produção, as características da fibra muscular desempenham um papel chave na qualidade da carne. A ontogênese da miofibra inicia muito cedo durante a vida embrionária, com o aparecimento de duas (aves e roedores) ou três (bovinos, ovinos e suínos) ondas sucessivas de mioblastos que constituem a origem dos diferentes tipos de fibra muscular. $\mathrm{O}$ número de ondas parece estar relacionado ao tamanho do animal e também ao número de fibras de um determinado músculo (Hauscka, 1994). Em aves, as duas gerações de fibras surgem durante os estádios: embrionário (geração primária) e fetal (geração secundária) de desenvolvimento. A primeira ocorrendo por volta de 3-7 dias de incubação e a segunda dos 8-16 dias de incubação (Bandman \& Rosser, 2000). Após as duas ondas de miogênese, ainda no estádio fetal de desenvolvimento, o número total de fibras é fixado. A primeira onda de colonização dos miotubos se origina dos mioblastos embrionários e a segunda dos mioblastos fetais dando origem às fibras musculares primárias e secundárias, respectivamente (Kalcheim et al., 1999, Picard et al., 2002).

A quantidade de massa muscular formada a partir dos mioblastos embrionários (fibras primárias) é extremamente pequena, porém estas fibras desempenham uma função importante no sentido de fornecer uma "armação" para as fibras secundárias. Por outro lado, a massa muscular de um vertebrado adulto é dependente da segunda onda de miogênese, onde as fibras secundárias contribuirão grandemente para o número de fibras que irão formar o músculo adulto (Patel et al., 2002; Wigmore \& Evans, 2002). Durante a segunda onda de miogênese, cada fibra primária pode ter várias fibras secundárias recém formadas, na sua superfície, que podem ser distinguidas das primárias pelo seu tamanho relativamente menor (Figura 4A). No final da miogênese, entre cinco e vinte fibras secundárias estarão na superfície de cada fibra primária, sendo que o número de fibras varia entre os diferentes músculos (Figura 4B). Neste ponto, a formação de novas fibras cessa e o crescimento das fibras secundárias juntamente com a diminuição do tamanho das fibras 
primárias torna impossível a distinção entre fibras primárias e secundárias no músculo adulto (Wigmore \& Evans, 2002).

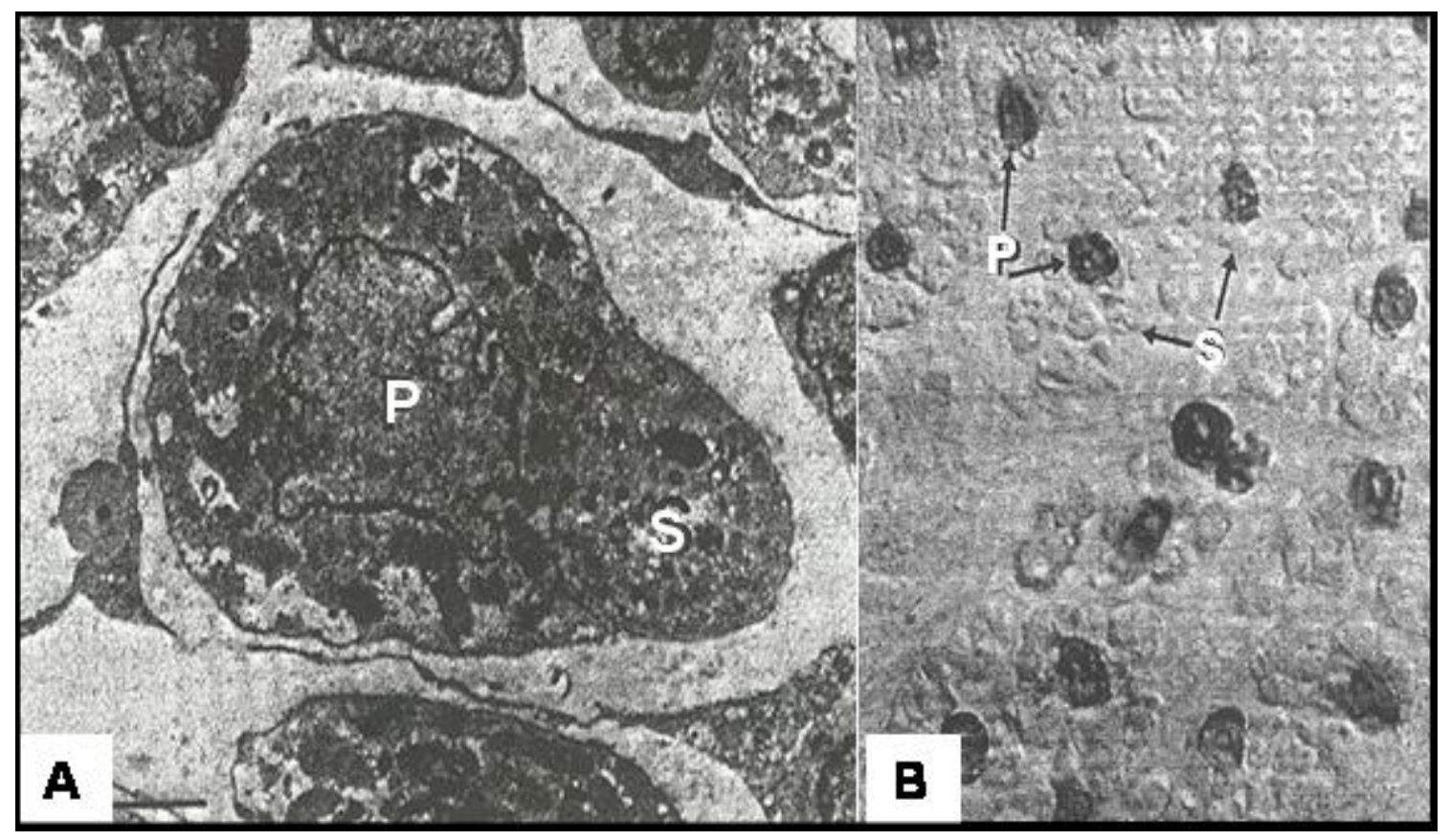

Figura 4 - A) Micrografia eletrônica de transmissão de um corte transversal do músculo de camundongo em desenvolvimento mostrando uma fibra muscular primária maior $(P)$ com uma fibra seundária menor (S) na sua superfície. B) Corte transversal de músculo mostrando as fibras primárias $(P)$ coradas e secundárias (S) não coradas Adaptado de Wigmore \& Evans, 2002

As fibras primárias geralmente amadurecem para fibras de contração lenta, enquanto as secundárias para fibras musculares de contração rápida, que expressam diferentes isoformas de proteínas contráteis (Perry \& Rudnick, 2000; Picard et al. 2002). A Figura 5 representa o processo de maturação da fibra muscular.

Em aves, as fibras formadas de mioblastos fetais diferem daquelas formadas por mioblastos embrionários em relação as isoformas de miosinas expressas (Patel et al., 2002). 


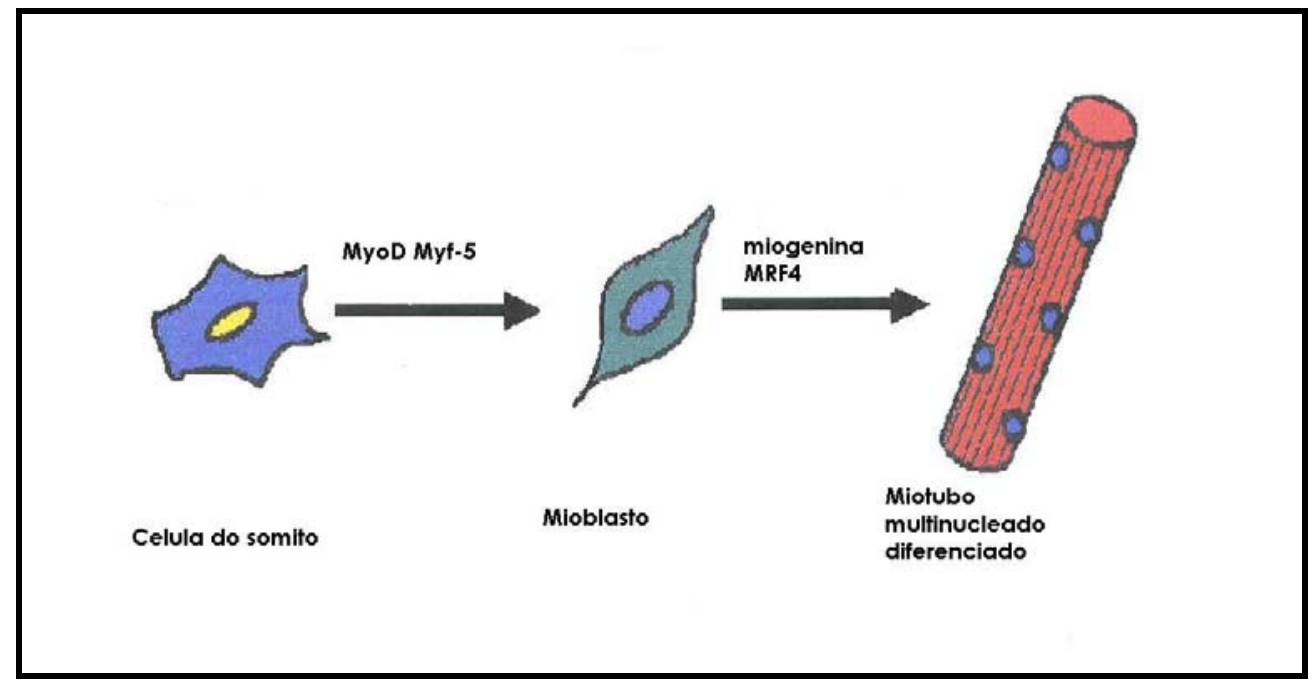

Figura 5 - Processo de maturação da fibra muscular que ocorre a partir dos mioblastos que se fundem em miotubos para a formação da fibra muscular

Fonte: adaptado de Perry \& Rudnick (2000)

\subsubsection{Tipos de fibras musculares}

A aparência estriada do músculo esquelético está relacionada ao arranjo regular das proteínas contráteis. Entretanto, a maioria das proteínas do sarcômero, (unidade estrutural da célula muscular), pode ocorrer em uma variedade de isoformas. Além disso, muitas proteínas sarcoméricas têm isoformas que são diferencialmente expressas em tipos de fibras musculares diferentes (Schiaffino \& Reggiani, 1996). A expressão sequencial das diferentes isoformas em diferentes fases do desenvolvimento muscular da ave é encontrada em várias proteínas incluindo: miosina, toponina, proteína C, tropomiosina e creatina quinase (Miller et al., 1985). 
A miosina é o principal componente do aparato contrátil do músculo esquelético. Cada molécula de miosina consiste de duas miosinas de cadeia pesada (MyHCs) cada qual tendo duas miosinas de cadeia leve (MLCs) associadas a elas. Várias isoformas de MyHCs têm sido identificadas em aves, sendo todas altamente conservadas (Tidyman et al., 1997).

Existe uma correlação positiva entre as características da fibra e a isoforma de miosina presente no músculo. Por esta razão, as isoformas de MyHCs são as mais comumente usadas na classificação dos tipos de fibras musculares (Wigmore \& Evans, 2002). Em aves, existem mais de 30 genes de MyHCs, sendo que 9 isoformas mostram ser diferencialmente expressas durante o desenvolvimento do músculo esquelético (Tabela 1). Em aves adultas, podem ser reconhecidas três classes de fibras musculares, baseadas na expressão de MyHCs de contração rápida e lenta, e são descritas como lentas, rápidas e mistas (lentas/rápidas).

Tabela 1. Isoformas de miosina em aves

\begin{tabular}{ll}
\hline \multicolumn{1}{c}{ Isoforma } & \multicolumn{1}{c}{ Descrição } \\
\hline Cemb1 & Isoforma de contração rápida (embrionária 1) \\
Cemb 2 & Isoforma de contração rápida (embrionária 2) \\
Cemb 3 & Isoforma de contração rápida (embrionária 3) \\
Cneo & Isoforma de contração rápida (neonatal) \\
Cadult & Isoforma de contração rápida (adulta) \\
sMyHC1 & Isoforma de contração lenta (lenta 1) \\
sMyHC2 & Isoforma de contração lenta (lenta 2) \\
Atrial/sMyHC3 & Isoforma de contração lenta (lenta 3) \\
Cvent & Isoforma ventricular \\
\hline
\end{tabular}

\subsection{Seqüências expressas (EST)}


A análise de seqüências expressas é um método eficiente para a obtenção de dados preliminares de uma biblioteca de cDNAs. Existe informação suficiente nas 200-400 bases de nucleotídeos seqüenciados das extremidades dos fragmentos de cDNA para a identificação preliminar de cDNAs e a localização dessas seqüências nos cromossomos (Adams et al., 1991). A análise das seqüências EST permite identificar os genes expressos em um determinado tecido, já que as bibliotecas de cDNA são sintetizadas a partir do RNA mensageiro. Além disso, a utilização desta metodologia também indica o nível de atividade dos diferentes genes no tecido, além de permitir comparações entre tecidos e estádios de desenvolvimento diferentes.

ESTs identificadas em espécies domésticas têm sido empregadas com o objetivo de elaborar mapas genéticos que integrem a informação dos mapas de ligação, desenvolvidos por estudos de segregação de marcadores, aos mapas citogenéticos, que localizam marcadores nos cromossomos, para facilitar a localização de genes candidatos para QTLs (Quantitative Trait Loci). Estes mapas podem fornecer contribuições importantes para os programas de melhoramento genético animal, facilitando a seleção de animais com características específicas para a produção. Uma biblioteca de clones de cDNA derivada do baço de galinha foi elaborada e dez seqüências ESTs foram identificadas para o genoma de galinha. As seqüências de cinco ESTs revelaram identidade com genes de mamíferos. Estes resultados mostraram que as seqüências ESTs são eficientes ferramentas para adicionar genes candidatos ao mapa de ligação de galinha, além de permitir a identificação de grupos de genes conservados entre galinha e espécies de mamíferos (Bumstead et al., 1994). Dentro deste contexto, Li et al. (1998) construíram uma biblioteca de fígado de galinha e um total de 92 ESTs foram identificadas. Desse total, $29 \%$ não tinham similaridade com genes conhecidos, 34\% mostraram similaridade com RNAr, 9\% com genes mitocondriais, 23\% com genes nucleares e $5 \%$ com ESTs humanas. 
Visando contribuir significativamente na análise do genoma de galinhas, Smith et. al. (2001b) construíram uma biblioteca normalizada de cDNA derivada de embriões de galinha de uma linhagem de poedeiras (White Leghorn) com 10 dias de idade. A biblioteca também foi avaliada por análises de SNP (Single Nucleotide Polimorphisms). Das 99 seqüências EST geradas, 51\% apresentaram identidade com seqüências já descritas. Um total de 19 ESTs apresentaram homologia com genes descritos em galinhas. O número de SNPs detectados variou de 0 a 4 de um total de 65 e apresentou uma freqüência de 1 a cada 470 bases. Estes resultados mostraram que o uso das seqüências EST é uma importante ferramenta para o estudo de novos genes em aves. A partir das ESTs identificadas foram construídos primers específicos para análise comparativa entre galinhas, codornas, galinhas d'angola e perus. A porcentagem de similaridade entre as seqüências destas espécies foi maior para comparações entre galinha, codorna e peru do que entre galinha d'angola e galinha, cordorna ou peru (Smith et al., 2001a). Em uma análise posterior, os SNPs identificados foram utilizados para comparações entre duas populações de linhagens comerciais, uma de corte e outra de postura. O número de SNPs observados variou de 0 a 10 em um total de 44 . Cerca de $70 \%$ dos polimorfismos foram compartilhados entre as duas populações de aves comerciais. Estes polimorfismos podem fornecer recursos para análises genéticas entre populações comerciais de frangos (Smith et al., 2002).

Em adição, em estudos feitos por Smith et al., (2000), 21 clones selecionados de uma biblioteca de cDNA de pituitária de perus foram seqüenciados para desenvolver ESTs, utilizando-se primers específicos para amplificar DNA genômico de peru, galinha, galinha d'angola, pombo e codorna. Os produtos amplificados foram seqüenciados e analisados para variações nas seqüências e similaridades entre as espécies. A proporção de bases compartilhadas entre as seqüências de peru e seqüências consenso para cada uma das outras espécies variou de 72 a 93\% entre peru, pombo e codorna e entre peru e galinha, respectivamente. As ESTs relatadas podem fornecer 
recursos para a elaboração de um mapa genômico de alta utilidade para perus e galinhas. Os primers utilizados podem ser usados como uma ferramenta em investigações futuras destinadas ao entendimento da biologia de galinhas d'angola, pombos e codornas e suas ligações com perus.

Além de ser utilizada como modelo de estudo em vertebrados, Gallus gallus representa um importante sistema experimental para biólogos de desenvolvimento, imunologistas, biólogos celulares e geneticistas. Em estudo recente, foram seqüenciadas 339.314 seqüências EST de 64 bibliotecas de cDNA de 21 tecidos diferentes provenientes das fases embrionária e adulta. Foram identificadas 85.486 seqüências únicas, e destas 38\% apresentaram identidade com seqüências de outras espécies. Com este conjunto de dados, foi estimado que galinhas apresentam aproximadamente 35000 genes (Boardman et al., 2002).

Com o intuito de caracterizar genes expressos na musculatura peitoral de suínos Davoli et al. (1999) construíram uma biblioteca do músculo bíceps femuris de suínos onde 111 clones foram seqüenciados. Foram identificadas 72 seqüências únicas, das quais 47 apresentaram identidade com seqüências de humanos, 20 não foram classificadas, outras duas apresentaram baixa similaridade. Os genes mitocondriais $(16,2 \%)$, miosinas de cadeia pesada (9\%) e $\alpha$ actina de músculo esquelético (9\%) foram os transcritos mais abundantes. Estes resultados permitiram o estabelecimento da primeira lista de genes expressos em musculatura de suínos.

\subsection{Single Nucleotide Polymorphisms (SNPs)}

Os polimorfismos de nucleotídeos únicos (SNPS) são resultantes de mutações pontuais e correspondem a posições onde existe uma alternância dos nucleotídeos A, C, G e T. Os SNPs podem estar presentes tanto em regiões codificadoras como em não codificadoras do genoma (Brookes, 1999). Em 
regiões codificadoras, quando resultam em uma substituição de aminoácido na seqüência protéica, são denominados não sinônimos, podendo a substituição ser considerada conservativa ou não conservativa em função das características dos aminoácidos envolvidos na troca. Nesses casos, podem ocorrer modificações estruturais e funcionais nas proteínas. As substituições mais freqüentes que ocorrem no DNA são as que envolvem bases nitrogenadas de mesma característica estrutural, ou seja, trocas entre duas purinas (A/G ou G/A) ou duas pirimidinas ( $C / T$ ou $T / C$ ) e são denominadas transições. Já as transversões são substituições de uma purina por uma pirimidina ou vice-versa. Caso essas mutações ocorram em células germinativas, sejam transmitidas às gerações seguintes e se fixem na população em uma freqüência mínima de 1\%, passam a ser consideradas polimorfismos (Brookes, 1999; Vignal et al., 2002)

A análise de SNPs tem sido empregada em diversas áreas tais como evolução, estudo comparativos entre espécies, genética de populações, produção animal, entre outras. A identificação de SNPs pode fornecer recursos para a construção de mapas genéticos comparativos entre espécies baseados na comparação de seqüências obtidas de vários animais (Vignal et al., 2002). A comparação de seqüências de dados obtidos em projetos EST, especialmente se as bibliotecas usadas forem construídas usando tecidos de vários indivíduos diferentes, pode ser uma boa fonte de SNPs que terão um interesse adicional e uma grande chance de originar regiões codificantes e portanto, ter influência nos fenótipos.

\subsection{PCR em Tempo Real}

O método de PCR quantitativo em tempo real é muito sensível e pode ser usado quando é necessário quantificar a expressão de RNAs mensageiros em baixos níveis. Este procedimento permite a detecção direta dos produtos da PCR durante a fase exponencial da reação, combinando amplificação e detecção em um só passo. 
O princípio da técnica de PCR em tempo real leva em consideração duas descobertas importantes: a primeira é a atividade exonuclease $5^{\prime} \rightarrow 3$ 'da enzima Taq DNA polimerase e a segunda é a construção de sondas de oligonucletídeos marcadas duplamente. Estas sondas são baseadas no princípio FRET (do inglês, Fluorescence Resonance Energy Transfer) e emitem sinal de fluorescência somente quando clivadas. Com o objetivo de detectar o sinal de fluorescência durante as reações foram desenvolvidas várias químicas. Em PCR em tempo real utilizando sondas TaqMan (Figura 6), a sonda, específica para o gene de interesse, é marcada duplamente com um corante repórter em uma extremidade e um corante "silenciador" na outra. Na forma livre, a transferência de energia fluorescente ocorre de forma que a emissão pelo repórter é absorvida pelo silenciador. Quando ocorre a degradação da sonda pela atividade nuclease da enzima Taq DNA polimerase, durante a PCR, os corantes repórter e silenciador são separados e a emissão de fluorescência do repórter não será mais absorvida pelo silenciador resultando em um aumento de emissão de fluorescência pelo repórter que será detectada e quantificada (Giulietti et al., 2001; Ginzinger, 2002).

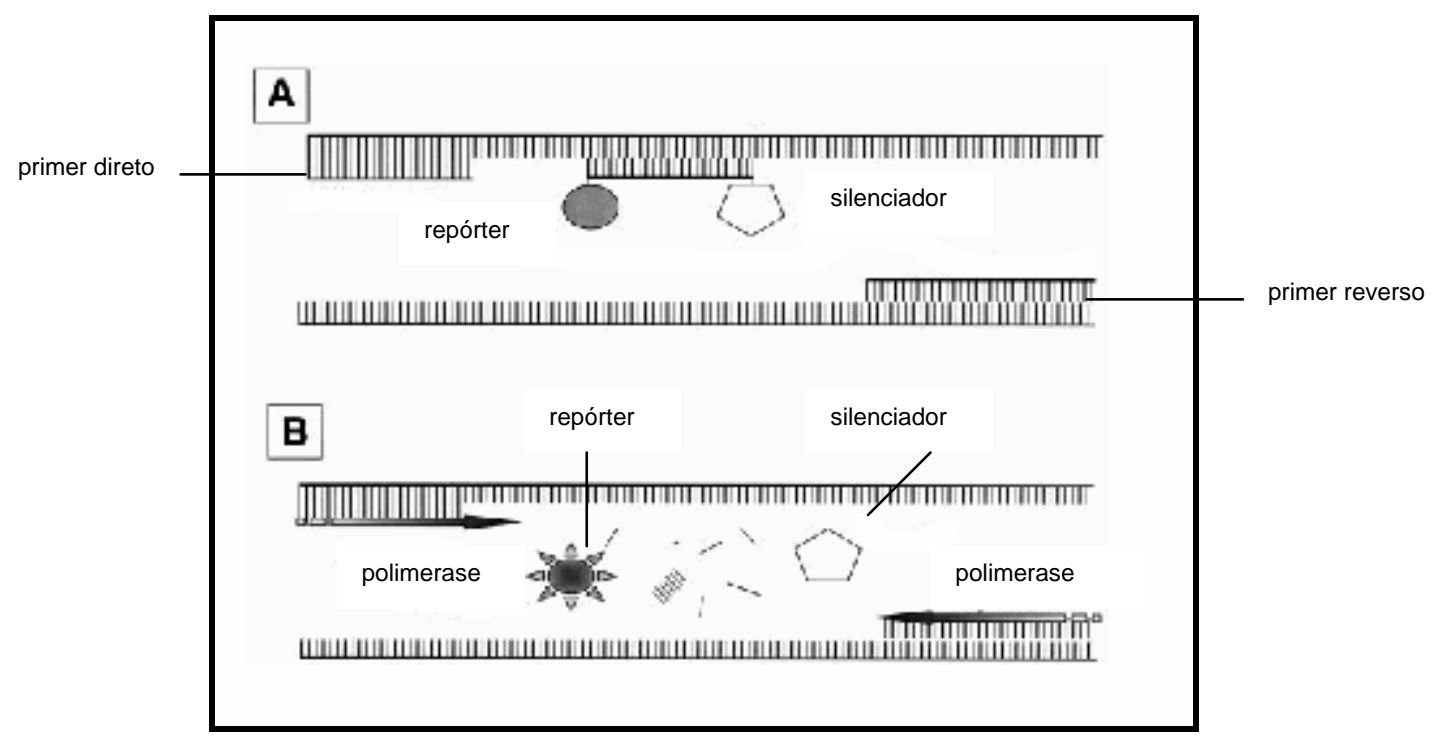


Figura 6 - Sistema TaqMan. (A) Após a desnaturação, os primers e a sonda anelam à seqüência alvo. A emissão de fluorescência não ocorre devido a proximidade entre o repórter e o silenciador. (B) Durante a fase de extensão, a sonda é clivada $\left(5^{\prime} \rightarrow 3^{\prime}\right)$ pela atividade nuclease da enzima Taq DNA polimerase. Então, repórter e silenciador são separados, permitindo a emissão de fluorescência pelo repórter

Adaptada de Giulietti et al., 2001

Mais recentemente, outros sistemas sofisticados têm sido desenvolvidos como, por exemplo, molecular beacons, scorpions e sondas para hibridização. Estes sistemas são baseados no princípio FRET, porém sem a necessidade de hidrólise por atividade nuclease.

Outra forma de detecção é a utilização de corantes como SYBR Green (Figura 7), que se liga ao DNA dupla fita emitindo fluorescência. O uso deste método de detecção, tem sido bastante empregado em ensaios de PCR quantitativo em tempo real, pois tem a vantagem de ser mais barato em relação a construção de sondas marcadas. Um aspecto importante no uso de SYBR Green é que os primers específicos utilizados na reação de PCR devem ser desenhados cuidadosamente para evitar a amplificação de produtos inespecíficos e formação de dímeros, uma vez que esse corante se liga a qualquer DNA dupla fita. 


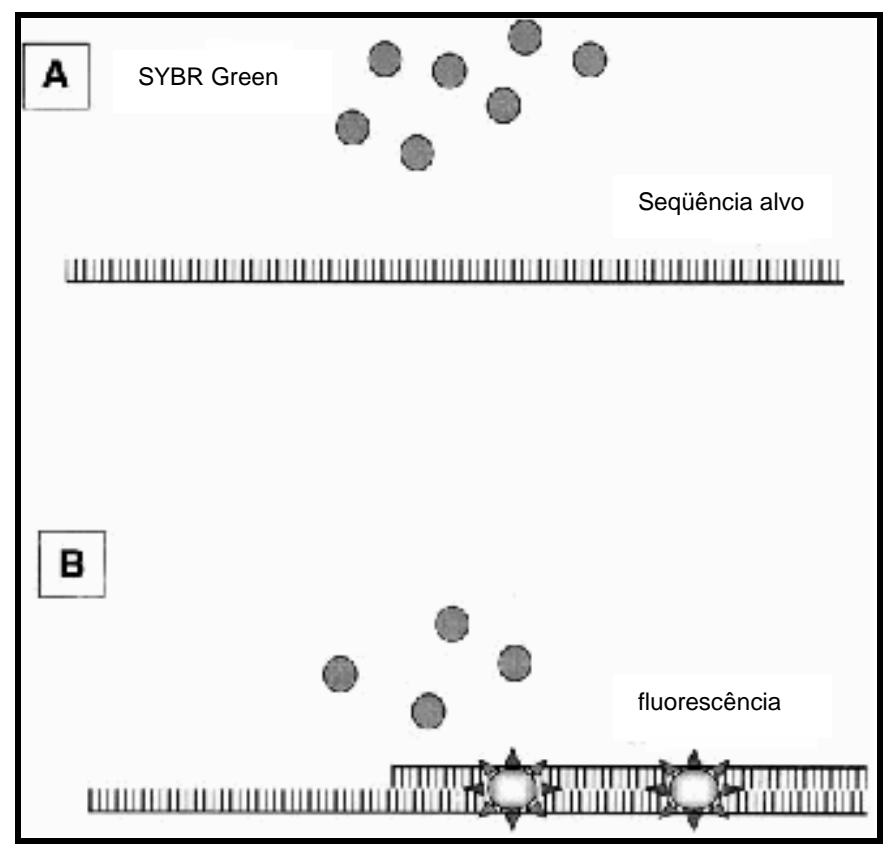

Figura 7 - Sistema SYBR Green. (A) O corante livre na solução não emite fluorescência. (B) Quando o corante se liga ao DNA fita dupla ocorre a emissão de fluorescência

Adaptada de Giulietti et al., 2001

Utilizando-se qualquer uma das químicas desenvolvidas, o aumento na emissão de fluorescência pode ser lido por um detector em tempo real, durante a reação de PCR e é uma conseqüência direta da amplificação da seqüência de DNA de interesse. Um programa de computador calcula um $\triangle R n$ usando a seguinte equação: $\triangle R n=R n^{+}-R n^{-}$, onde: $R n^{+}=$emissão de fluorescência em cada ponto; $\mathrm{Rn}^{-}=$emissão de fluorescência na linha de base.

O computador constrói os plots de amplificação usando os dados de emissão de fluorescência durante a PCR. Os valores de $\triangle R n$ são plotados vezes o número de ciclos de amplificação. Durante os ciclos iniciais da amplificação por PCR, os valores de $\triangle R n$ não excedem a linha de base. Portanto, um ciclo limiar (Ct) arbitrário é escolhido baseado na variação da linha de base. Os valores de Ct são então calculados por determinação do ponto no 
qual a fluorescência excede esse limiar escolhido. O Ct é definido como o número de ciclos nesse ponto (Figura 8) (Giulietti et al., 2001; Ginzinger, 2002).

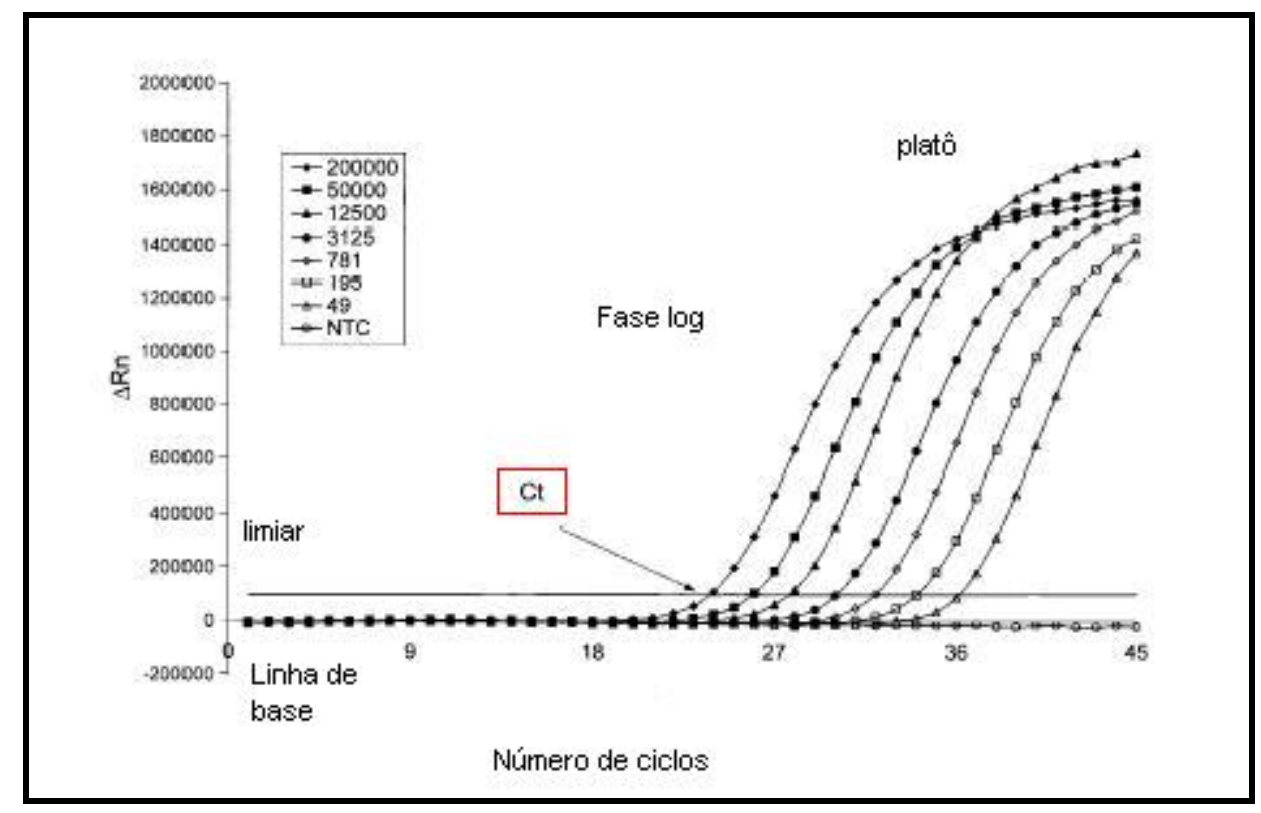

Figura 8 - Exemplo de construção dos plots de amplificação, onde $\triangle R n$ é plotado contra o número de ciclos

Adaptada de Giulietti et al., 2001

Existem dois métodos mais comumente utilizados para analisar dados de experimentos de PCR quantitativo em tempo real, são eles: o método de quantificação absoluta (método da curva padrão) e o método de quantificação relativa.

Método de quantificação absoluta - O número de cópias do gene de interesse é determinado relacionando-se o sinal da PCR com uma curva padrão. Para a construção da curva padrão são utilizadas diluições seriais de uma amostra de concentração conhecida. Este método tem a vantagem de que a curva padrão incluída em cada PCR fornece um controle extra e correção na eficiência da PCR de cada amostra individual, tornando mais confiáveis as comparações entre experimentos. 
Método de quantificação relativa - Este método é mais usado quando existem muitos genes a serem testados em muitas amostras. Neste caso, é feita a relação entre o sinal da $\mathrm{PCR}$ de um gene de interesse entre um grupo tratado com uma amostra controle (por exemplo, uma amostra não tratada). Este procedimento tem a vantagem de não necessitar da construção de curvas padrão. Por outro lado, as eficiências de amplificação dos genes de interesse e controle têm que ser similares para a obtenção de resultados confiáveis.

Em ambos métodos são utilizados genes constitutivos para a normalização das amostras. Tais genes devem ter expressão constante em todos os tecidos e todas as fases de desenvolvimento, bem como não serem afetados pelos tratamentos experimentais. O gene mais utilizado com esta finalidade é o gene da $\beta$ - actina.

$O$ método de PCR quantitativo em tempo real tem se mostrado uma ferramenta de extrema importância na quantificação de RNAs mensageiros em baixos níveis, tornando a quantificação mais rápida e acurada (Giulietti et al., 2001; Livak \& Schmittgen, 2001; Ginzinger, 2002). 


\section{MATERIAL E MÉTODOS}

\subsection{Incubação dos ovos e coleta dos tecidos}

Ovos férteis provenientes do Setor de Melhoramento Genético de Aves (SMGA - EMBRAPA - Suínos e Aves - Concórdia, SC), das linhagens TT (corte) e CC (postura) foram incubados a $37,8^{\circ} \mathrm{C}$ em atmosfera umidificada por 9 e 17 dias correspondendo aos estádios E35 e E43, respectivamente, segundo Hamburger \& Hamilton (1951). Para a biblioteca da fase pós-eclosão foram utilizadas aves com 1 e 21 dias de idade. Após a incubação foi realizada a coleta dos embriões, dissecação da musculatura peitoral e maceração dos tecidos congelados em nitrogênio líquido. A baixa temperatura é essencial para evitar que com o rompimento das células as RNases endógenas destruam o RNA que será utilizado para a síntese de cDNA.

O tecido peitoral dos embriões nos estádios E35 e E43 foram utilizados para a construção das bibliotecas da fase embrionária denominadas: EB1 (linhagem TT) e EB2 (linhagem CC). Para a biblioteca da fase pós-eclosão denominada CB1 (linhagem TT), foram utilizadas amostras de tecido peitoral de pintinhos de 1 dia e aves de 21 dias de idade. Na Figura 9 podem ser visualizados embriões representando as idades utilizadas para a construção das bibliotecas, bem como as aves com 1 e 21 dias de idade. A idade de 9 dias foi escolhida pelo fato da musculatura peitoral estar formada no embrião e as idades subseqüentes, para abranger vários estádios de desenvolvimento do músculo peitoral das aves. As Figuras 10 e 11 representam os estádios E35 e 
E43 do desenvolvimento embrionário de embriões de galinha, segundo Hambuger \& Hamilton, 1951.

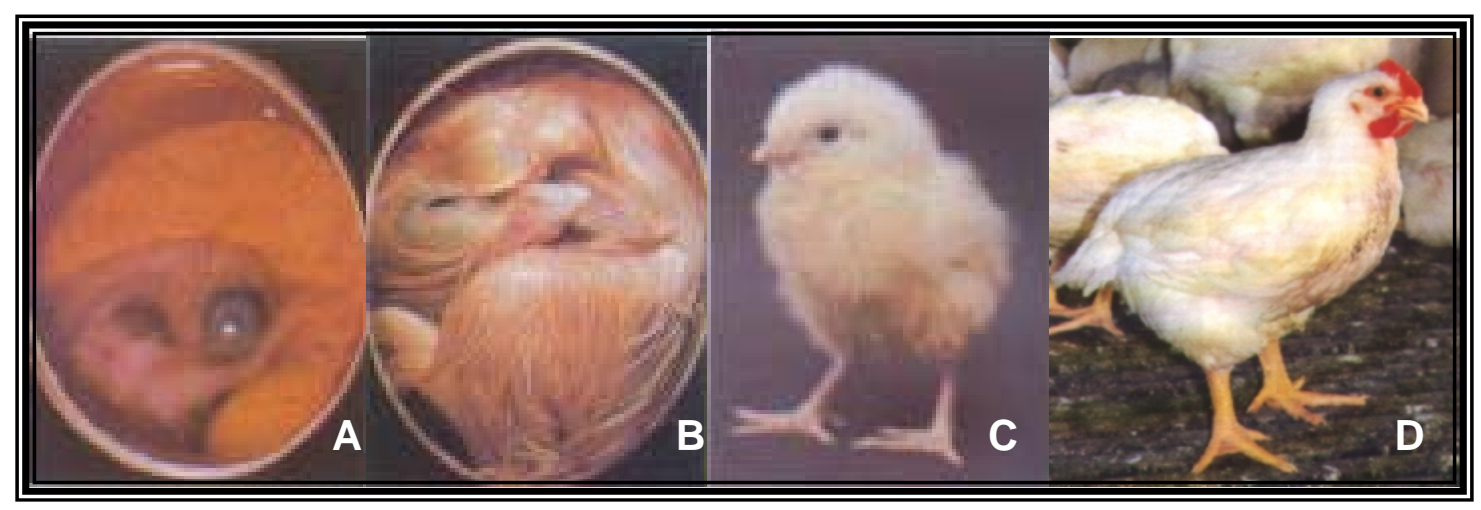

Figura 9 - Fotografias das aves representando as idades utilizadas para a dissecação do tecido peitoral. A) Embrião de 9 dias de incubação. B) Embrião de 17 dias de incubação. C) Pintinho de 1 dia de idade. D) Frango de 21 dias de idade

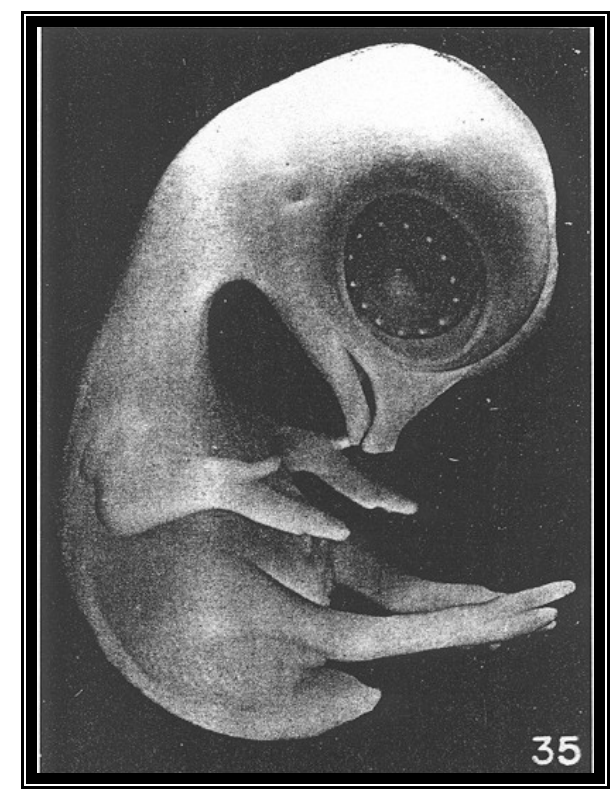

Figura 10 - Embrião de galinha com 9 dias de incubação, estádio E35 Fonte: Hamburger \& Hamilton (1951) 


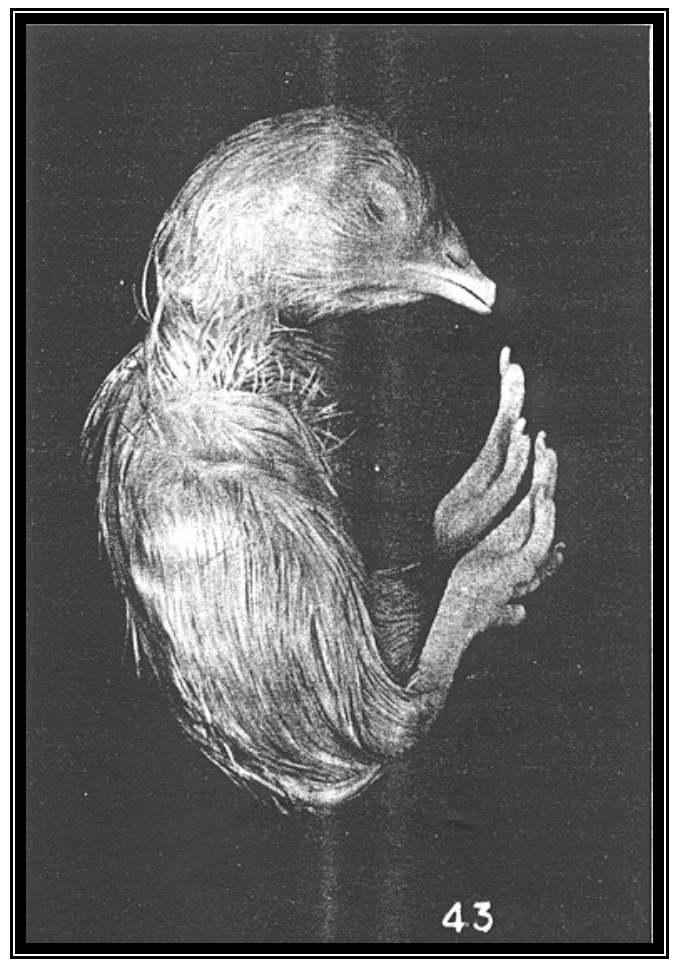

Figura 11 - Embrião de galinha com 17 dias de incubação, estádio E43 Fonte: Hamburger e Hamilton (1951)

\subsubsection{Pesagens}

$\mathrm{Na}$ idade de 9 dias de incubação foram pesados os ovos, bem como os embriões inteiros das duas linhagens. Na idade de 17 dias, além da pesagem dos ovos e embriões, foram também pesados os músculos peitorais. Já nas idades de 1 e 21 dias, foram feitas pesagens das aves e também dos músculos peitorais. 


\subsubsection{Extração de RNA total}

O RNA total foi isolado dos tecidos conforme metodologia descrita por Chomczynski \& Sacchi (1987). Os tecidos coletados foram dissolvidos em $750 \mu \mathrm{L}$ de solução TRIZOL (Invitrogen) e $250 \mu \mathrm{Lde}$ água tratada com 0,01\% dietilpirocarbonato $\left(\mathrm{H}_{2} \mathrm{O}_{\text {DEPC }}\right)$. A esta mistura foram adicionados $200 \mu \mathrm{L}$ de clorofórmio, seguindo-se incubação por 10 a 15 min., à temperatura ambiente. Após centrifugação a $12.000 \times \mathrm{g}$ por 15 min., a $4{ }^{\circ} \mathrm{C}$, recuperou-se a fase aquosa (fase superior) e adicionaram-se $500 \mu \mathrm{L}$ de isopropanol, incubando-se as amostras por 10 a 15 min. à temperatura ambiente. As amostras foram centrifugadas a $10.000 \times \mathrm{g}$, por 10 min., a $4{ }^{\circ} \mathrm{C}$ e o precipitado de RNA foi lavado em $1 \mathrm{~mL}$ de etanol $70 \%$, sendo procedida nova centrifugação nas mesmas condições anteriores. O precipitado de RNA foi seco à temperatura ambiente e ressuspendido em $20 \mu \mathrm{L}$ de $\mathrm{H}_{2} \mathrm{O}_{\text {DEPC }}$ para posterior determinação da concentração por espectrofotometria. As amostras foram submetidas à eletroforese em gel de agarose $1 \%$ para verificar a integridade do RNA total.

\subsubsection{Isolamento de RNA mensageiro}

$\mathrm{O}$ isolamento de RNA mensageiro das amostras de RNA total foi feito com o Kit Message Maker (Invitrogen). Foram utilizados $2 \mathrm{mg}$ de RNA total proveniente do tecido peitoral dos embriões. Inicialmente, o RNA total $(0,55 \mathrm{mg} / \mathrm{mL})$ foi aquecido a $65^{\circ} \mathrm{C}$, por $5 \mathrm{~min}$., e resfriado em gelo. A seguir, foi acrescentado 0,1 volume de $\mathrm{NaCl} 5 \mathrm{M}$, seguido por $2 \mathrm{~mL}$ de oligo dT $(0,5 \mathrm{M}$ $\mathrm{NaCl}, 20 \mathrm{mM}$ Tris- $\mathrm{HCl}, \mathrm{pH}$ 7,5, 0,05 \% azida sódica) e então aquecido a $37^{\circ} \mathrm{C}$, por 10 minutos. Foi feita a transferência do RNA total + oligo dT para uma seringa, os quais foram misturados e expelidos. A primeira seleção de RNA mensageiro foi realizada lavando-se o filtro da seringa com $5 \mathrm{~mL}$ de Wash Buffer $1(0,5 \mathrm{M} \mathrm{NaCl}, 20 \mathrm{mM}$ Tris- $\mathrm{HCl}, \mathrm{pH}$ 7,5), $5 \mathrm{~mL}$ de Wash Buffer $2(0,1 \mathrm{M}$ 
$\mathrm{NaCl}, 20 \mathrm{mM}$ Tris- $\mathrm{HCl}, \mathrm{pH} 7,5)$ e $2 \mathrm{~mL}$ de água destilada aquecida a $65^{\circ} \mathrm{C}$, sendo então, expelido em tubo limpo e aquecido a $65^{\circ} \mathrm{C}$, por 5 minutos. A seguir, foi adicionado 0,1 volume de $\mathrm{NaCl} 5 \mathrm{M}$ e procedida uma segunda seleção de RNA mensageiro, seguindo mesmas condições da primeira. O RNA mensageiro foi precipitado acrescentando-se $5 \mu \mathrm{L}$ de glicogênio, $200 \mu \mathrm{L}$ de acetato de amônio $7,5 \mathrm{M}, 2$ volumes de etanol absoluto e mantido a $-20^{\circ} \mathrm{C}$ por 16 horas. Após centrifugação a 2.600 x g por $30 \mathrm{~min}$. a $4{ }^{\circ} \mathrm{C}$, o precipitado foi lavado com $4 \mathrm{~mL}$ de etanol $75 \%$ a $2.600 \times$ g por 10 min. a $4{ }^{\circ} \mathrm{C}$. O RNA mensageiro foi seco à temperatura ambiente e dissolvido em $9 \mu \mathrm{L}$ de $\mathrm{H}_{2} \mathrm{O}_{\text {DEPC }}$.

\subsubsection{Construção das bibliotecas de cDNA}

Para a construção das bibliotecas de cDNA da fase embrionária (embriões de 9 e 17 dias de incubação) e fase pós eclosão (aves de 1 e 21 dias

de idade) foi utilizado o Kit Superscript ${ }^{T M}$ Plasmid System with Gateway ${ }^{T M}$ Technology for cDNA Synthesis and Cloning (Invitrogen). Para tanto, foram realizadas as seguintes etapas:

\subsubsection{Síntese da primeira fita de cDNA}

Ao RNA mensageiro foram adicionados $2 \mu \mathrm{L}$ de Not I primer adapter $(0,5$ $\mu \mathrm{g} / \mu \mathrm{L})$, um primer oligo $(d T)$ associado a um adaptador contendo um sítio de restrição para a enzima Not I sendo a mistura aquecida a $70^{\circ} \mathrm{C}$, por $10 \mathrm{~min}$., resfriada em gelo e centrifugada rapidamente. A seguir foram adicionados $4 \mu \mathrm{L}$ de First Standard Buffer $5 X$ [250 mM Tris- $\mathrm{HCl}(\mathrm{pH}$ 8,3), $375 \mathrm{mM} \mathrm{KCl}, 15 \mathrm{mM}$ $\mathrm{MgCl}_{2}$ ]; $2 \mu \mathrm{L}$ de DTT 0,1 M e $1 \mu \mathrm{L}$ de dNTP mix $10 \mathrm{mM}$. Após a adição, os reagentes foram misturados e centrifugados rapidamente. Procedeu-se, então, 
a incubação por 2 min. a $37^{\circ} \mathrm{C}$ para equilibrar a temperatura. O passo seguinte foi a adição de $2 \mu \mathrm{L}$ da enzima Superscript // e incubação a $37^{\circ} \mathrm{C}$ por 2 horas, sendo a reação terminada no gelo.

\subsubsection{Síntese da segunda fita de cDNA}

Nesta etapa, foram adicionados os reagentes, em gelo, na seguinte ordem: $93 \mu \mathrm{L}$ de $\mathrm{H}_{2} \mathrm{O}$ DEPC, $30 \mu \mathrm{L}$ de Second Standard Buffer $5 X$ [100 mM Tris$\mathrm{HCl}(\mathrm{pH}$ 6,9), $450 \mathrm{mM} \mathrm{KCL}, 23 \mathrm{mM} \mathrm{MgCl}, 0,75 \mathrm{mM} \beta-\mathrm{NAD+}, 50 \mathrm{mM}$ $\left.\left(\mathrm{NH}_{4}\right)_{2} \mathrm{SO}_{4}\right] ; 3 \mu \mathrm{L}$ de dNTP mix $10 \mathrm{mM} ; 1 \mu \mathrm{L}$ de $E$. coli DNA ligase $(10 \mathrm{U} / \mu \mathrm{L}) ; 4$ $\mu \mathrm{L}$ de $E$. coli DNA polimerase I (10 U/ $\mu \mathrm{L})$ e $1 \mu \mathrm{L}$ de $E$. coli Rnase $\mathrm{H}(2 \mathrm{U} / \mu \mathrm{L})$.

A reação foi homogeneizada e incubada por 2 horas a $16^{\circ} \mathrm{C}$. Foram adicionados então $2 \mu \mathrm{L}$ de T4 DNA polimerase e continuou-se a incubação a 16 ${ }^{\circ} \mathrm{C}$ por mais 5 minutos. A reação foi transferida para gelo e adicionados $10 \mu \mathrm{L}$ de EDTA 0,5 M para interrompê-la completamente.

A seguir, foram adicionados $150 \mu \mathrm{L}$ de fenol:clorofórmio:álcool isoamílico (25:24:1) à reação, misturando-se completamente os reagentes e procedendose centrifugação por $15 \mathrm{~min}$. a $14.000 \times \mathrm{g}$ para a separação das fases. Ao sobrenadante recuperado foram adicionados $70 \mu \mathrm{L}$ de $\mathrm{NH}_{4} \mathrm{Oac} 7,5 \mathrm{M}$ e $500 \mu \mathrm{L}$ de etanol absoluto $\left(-20^{\circ} \mathrm{C}\right)$, os quais foram centrifugados imediatamente a $14.000 \times \mathrm{g}$ por $20 \mathrm{~min}$. à temperatura ambiente. Ao pellet obtido foram adicionados $500 \mu \mathrm{L}$ de etanol $70 \%\left(-20^{\circ} \mathrm{C}\right)$, seguindo-se centrifugação por 2 min. $/ 14.000 \times$ g. O CDNA foi seco a $37{ }^{\circ} \mathrm{C}$ por $10 \mathrm{~min}$. para eliminar o etanol residual. 


\subsubsection{Adição do adaptador Sal I}

Nesta fase, o pellet de cDNA obtido no passo anterior foi ressuspendido em $25 \mu \mathrm{L}$ de $\mathrm{H}_{2} \mathrm{O}_{\text {DEPC; }}$ ao cDNA ressuspendido foram adicionados $10 \mu \mathrm{L}$ de T4 Ligase Buffer $5 \mathrm{X}$ [250 mM Tris- $\mathrm{HCl}\left(\mathrm{pH}\right.$ 7,6), $50 \mathrm{mM} \mathrm{MgCl}_{2}, 5 \mathrm{mM}$ ATP, $5 \mathrm{mM}$ DTT, 25\% (w/v) PEG 8000]; $10 \mu \mathrm{L}$ de Adaptador Sal I e $5 \mu \mathrm{L}$ de T4 DNA ligase.

Após homogeneização, foi incubado a $16{ }^{\circ} \mathrm{C}$ por no mínimo 16 horas. Após este período, adicionou-se $50 \mu \mathrm{L}$ de fenol:clorofórmio:álcool isoamílico (25:24:1) à reação, misturou-se e foi feita centrifugação a 14000 x g por 5 min. à temperatura ambiente para a separação das fases. Foram adicionados $25 \mu \mathrm{L}$ de $\mathrm{NH}_{4}$ OAc e $150 \mu \mathrm{l}$ de etanol absoluto $\left(-20^{\circ} \mathrm{C}\right)$ ao volume recuperado, os quais foram centrifugados por $20 \mathrm{~min} . / 14.000 \times \mathrm{g}$ à temperatura ambiente. $\mathrm{O}$ sobrenadante foi removido e foram adicionados $500 \mu \mathrm{L}$ de etanol $70 \%\left(-20^{\circ} \mathrm{C}\right)$, procedendo-se nova centrifugação a $14.000 \times$ g por 2 minutos. O cDNA foi seco a $37^{\circ} \mathrm{C}$ por 10 min. para a evaporação do etanol residual.

\subsubsection{Digestão com Not I}

Ao produto obtido no item 3.1.3.3 foram adicionados os reagentes na seguinte ordem: $41 \mu \mathrm{L}$ de $\mathrm{H}_{2} \mathrm{O}_{\text {DEPC; }} 5 \mu \mathrm{L}$ de React III buffer e $4 \mu \mathrm{L}$ da enzima de restrição Not I (15 U/ $\mu \mathrm{L})$. A seguir, foram feitas a homogeneização e incubação por duas horas a $37^{\circ} \mathrm{C}$. Realizou-se, uma terceira precipitação da mesma forma que a descrita anteriormente. Após secagem do cDNA a $37^{\circ} \mathrm{C}$, por 10 min., para a evaporação do etanol residual, o mesmo foi ressuspendido em 50 $\mu \mathrm{L}$ de TEN buffer [10 mM Tris- $\mathrm{HCl}(\mathrm{pH}$ 7,5), 0,1 mM EDTA; $25 \mathrm{mM} \mathrm{NaCl}$.

Os passos realizados para a elaboração da biblioteca estão resumidos na Figura 12. 


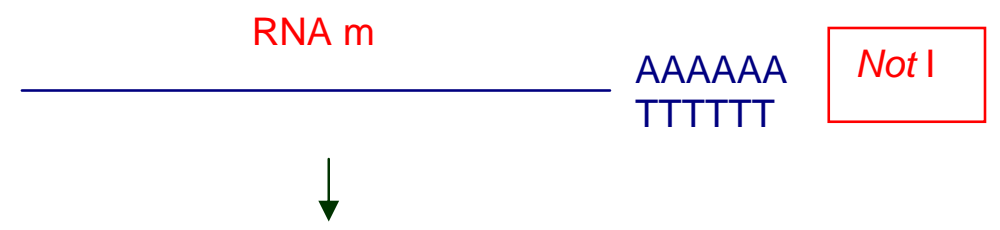

Síntese da $1^{\mathrm{a}}$ fita

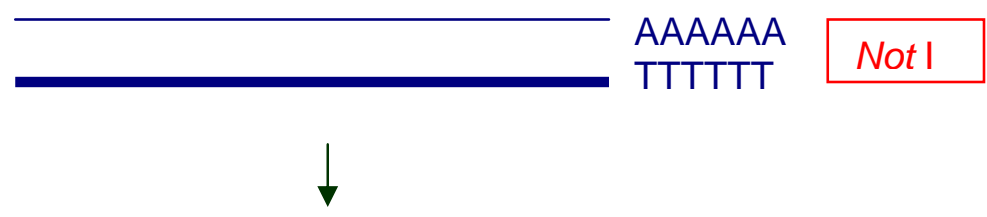

Síntese da $2^{\mathrm{a}}$ fita

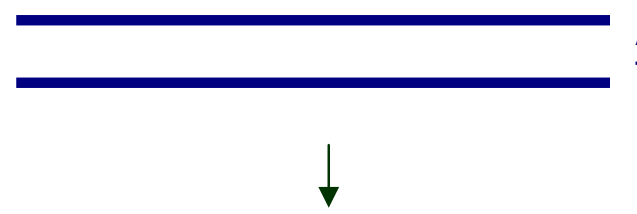

AAAAAA TTTTTT

Adição adaptador Sal I

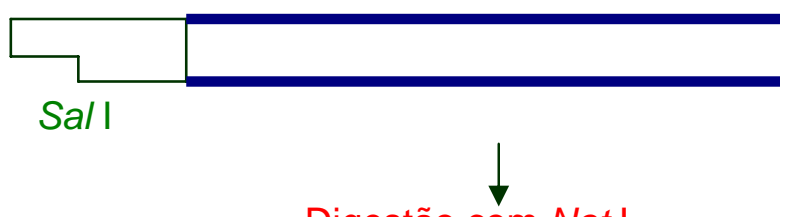

AAAAAA TTTTTT

Digestão com Not I
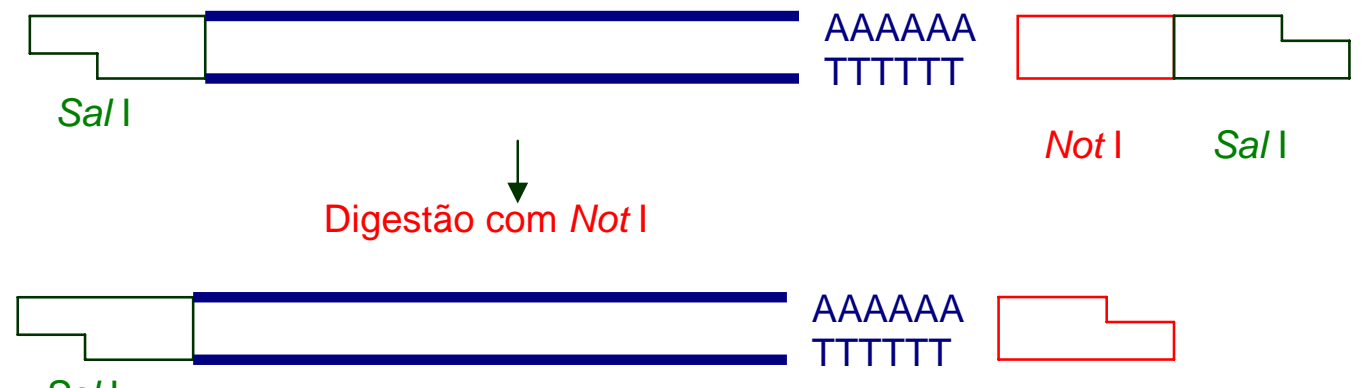

AAAAAA TTTTTT Sal I

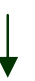

Ligação no vetor

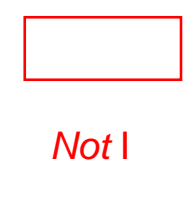

Not I Sal I

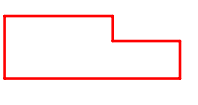

Not I 


\subsubsection{Fracionamento do cDNA}

O cDNA foi fracionado seguindo-se as especificações do Kit Superscript

${ }^{T M}$ Plasmid System with Gateway ${ }^{T M}$ Technology for CDNA Synthesis and Cloning (Invitrogen). Para tanto, foram feitas em uma coluna cromatográfica sucessivas lavagens com TEN buffer obtendo-se no final 20 frações correspondendo ao tamanho dos fragmentos a serem clonados posteriormente. A amostra de cDNA $(50 \mu \mathrm{L})$ foi adicionada à coluna e coletada em tubo numerado 1 . Em seguida, foram adicionados $100 \mu \mathrm{L}$ de TEN buffer à coluna e coletados completamente no tubo 2. Iniciando com a próxima alíquota de $100 \mu \mathrm{L}$ de TEN buffer, foi coletada 1 gota em tubos individuais, coletando-se um total de 18 gotas dos tubos 3 a 20, 1 gota por tubo, sendo que cada 100 $\mu \mathrm{L}$ corresponderam a 3 gotas. Usando-se uma pipeta automática, mediu-se o volume de cada tubo, registrou-se cada valor em uma tabela e foi calculado o volume cumulativo. Identificou-se então, a fração para a qual o valor cumulativo estivesse mais próximo, mas não excedendo a $550 \mu \mathrm{L}$. Estas frações, normalmente correspondentes aos tubos 15 ao 20, não foram utilizadas para a ligação por conterem cDNAs pequenos (menores que 500pb) e adaptadores não ligados. Foram selecionadas três frações, sendo que na fração 1 foram reunidas as alíquotas das frações 6, 7 e 8 (correspondendo as maiores), na fração 2, as alíquotas 9, 10 e 11 e na fração 3, as alíquotas, 12, 13 e 14. O volume de cada uma das frações foi concentrado até $10 \mu \mathrm{L}$ com o auxílio de Speed Vac, modelo RUT 4104-230 Savant.

\subsubsection{Ligação ao vetor pSPORT 1}

O cDNA fracionado (1-2 $\mu \mathrm{L}$ ) foi empregado nas reações de ligação, adicionado-se $0,5 \mu \mathrm{L}$ de vetor pSPORT 1 (50ng/ $\mu \mathrm{L}) ; 2,0 \mu \mathrm{L}$ de Tampão da 
ligase [250 mM Tris- $\mathrm{HCl}(\mathrm{pH}$ 7,6), $50 \mathrm{mM} \mathrm{MgCl}$, 5 mM ATP, $5 \mathrm{mM}$ DTT, 25\% $(w / v)$ PEG 8000]; 1,0 $\mu \mathrm{L}$ da enzima T4 DNA ligase (1 $\mathrm{U} / \mu \mathrm{L})$, em um volume final de $10 \mu \mathrm{L}$. Após homogeneização dos reagentes, as reações foram incubadas a $16{ }^{\circ} \mathrm{C}$ por 16 horas.

\subsection{Preparação das células competentes e transformação por choque térmico}

Para a preparação das bactérias competentes utilizadas na transformação, utilizou-se o protocolo descrito por Hanahan (1985).

No dia anterior à preparação das células competentes, E. coli $\mathrm{DH} 5 \alpha$ foi inoculada em uma placa contendo meio LB ágar. Uma colônia isolada foi novamente inoculada em $3 \mathrm{~mL}$ de meio SOB (triptona $2 \% ; 0,5 \%$ de extrato de levedura; $10 \mathrm{mM} \mathrm{NaCl} ; 2,5 \mathrm{mM} \mathrm{KCl} ; 10 \mathrm{mM} \mathrm{MgCl} 2$ e $10 \mathrm{mM} \mathrm{MgSO}_{4}$ ), e incubada sob agitação por 12 horas. Desse pré-inóculo foram transferidos 50 $\mu \mathrm{L}$ para $50 \mathrm{~mL}$ de meio SOB, que foi agitado por, aproximadamente, 3 horas a $37^{\circ} \mathrm{C}$. Medidas da densidade óptica (O.D.) foram realizadas de hora em hora para monitorar o crescimento das células até atingir O.D. $600 \mathrm{~nm}=0,5-0,6$. Atingida a O.D. desejada, adicionou-se $500 \mu \mathrm{L}$ de $\mathrm{MgCl}_{2} 1 \mathrm{M}$ e as células foram mantidas em gelo por 15 minutos. Seguiu-se centrifugação a $2.800 \times$ g por 10 min. a $4{ }^{\circ} \mathrm{C}$. O sobrenadante foi descartado e o pellet ressuspendido em $10 \mathrm{~mL}$ de RF I (100 mM KCl; 10 mM MnCl $2.4 \mathrm{H}_{2} \mathrm{O} ; 30 \mathrm{mM}$ acetato de potássio; $10 \mathrm{mM}$ $\mathrm{CaCl}_{2} \cdot 2 \mathrm{H}_{2} \mathrm{O}$; glicerol $15 \%$ ). O material em suspensão permaneceu por $15 \mathrm{~min}$. em gelo e foi centrifugado a $800 \times \mathrm{g}$ durante $10 \mathrm{~min}$. a $4{ }^{\circ} \mathrm{C}$. O sobrenadante foi descartado e o pellet ressuspendido em $2 \mathrm{~mL}$ de RF II (10 mM Na-MOPs, 10 $\mathrm{mM} \mathrm{KCl}, 75 \mathrm{mM} \mathrm{CaCl}_{2} \cdot 2 \mathrm{H}_{2} \mathrm{O}$, glicerol $15 \%$ ). Alíquotas de $100 \mu \mathrm{L}$ de células competentes foram pré-resfriadas em gelo, imediatamente congeladas em nitrogênio líquido e estocadas a $-80^{\circ} \mathrm{C}$. 
A transformação foi feita por choque térmico, onde cada reação de ligação $(10 \mu \mathrm{L})$ foi acrescentada a uma alíquota de $100 \mu \mathrm{L}$ de $E$. coli $\mathrm{DH} 5 \alpha$ competente, que permaneceu em gelo por 5 minutos. Este material foi incubado por 20 min. em gelo e, então, submetido a um choque térmico a $42{ }^{\circ} \mathrm{C}$ por 90 segundos e colocado novamente em gelo por 2 minutos. Imediatamente foram adicionados às células $900 \mu \mathrm{L}$ de meio SOC (triptona $2 \%$, extrato de levedura $0,5 \% ; 10 \mathrm{mM} \mathrm{NaCl} ; 10 \mathrm{mM} \mathrm{MgCl} 2 ; 2,5 \mathrm{mM} \mathrm{KCl}$ e $100 \mathrm{mM} \mathrm{MgSO}_{4}$ ). As amostras foram incubadas por 1 hora a $37^{\circ} \mathrm{C}$.

Do volume total de reação de transformação $(1 \mathrm{~mL})$, foram empregados $100 \mu \mathrm{L}$ para plaqueamento em meio LB ágar com ampicilina $(50 \mu \mathrm{g} / \mathrm{mL})$ e X-gal (20 mg/mL). As placas foram mantidas invertidas na estufa a $37{ }^{\circ} \mathrm{C}$ por 12 horas. Verificado o sucesso da transformação, os $900 \mu \mathrm{L}$ restantes foram igualmente plaqueados.

\subsection{Mini-preparação do DNA plasmidial}

As colônias obtidas foram inoculadas em placas (96 poços) contendo meio Circle Grow com ampicilina (100 mg/mL), sendo, em seguida, incubadas a $37^{\circ} \mathrm{C}$ por 22 horas sob agitação constante de $300 \mathrm{rpm}$.

Para a sedimentação das células as placas foram centrifugadas a 3.200 x $\mathrm{g}$ por $6 \mathrm{~min}$. à temperatura ambiente e o sobrenadante foi descartado por inversão. Ao pellet foram adicionados $240 \mu \mathrm{L}$ de GET (glicose 20 \%; 0,5 M EDTA, pH 8,0 e 1 M Tris- $\mathrm{HCl}$ pH 7,4), seguindo-se homogeneização em vortex por 5 minutos. Após nova centrifugação o sobrenadante foi descartado por inversão. A cada poço foram adicionados $80 \mu \mathrm{L}$ de GET, misturando-se em seguida. Para a degradação do RNA transferiu-se $60 \mu \mathrm{L}$ de cada suspensão de células para uma microplaca contendo $2,5 \mu \mathrm{L}$ de RNase $(10 \mathrm{mg} / \mathrm{mL})$. Adicionouse uma solução de hidróxido de sódio ( $\mathrm{NaOH}$ 0,2 N) com SDS 1 \% (dodecil 
sulfato de sódio) misturando-se, em seguida, por inversão. Após incubação por 10 min. à temperatura ambiente, acrescentou-se a cada poço $60 \mu \mathrm{L}$ de acetato de potássio $3 \mathrm{M}$ (solução neutralizadora) resfriado a $4{ }^{\circ} \mathrm{C}$, novamente misturouse e incubou-se. A microplaca foi colocada na estufa a $90^{\circ} \mathrm{C}$ por $30 \mathrm{~min}$. e, em seguida, resfriada em gelo por 10 minutos. Após centrifugação a 3.200 x g por 4 min. à temperatura ambiente, transferiu-se todo o volume para uma placa filtro millipore (MAGV N22) encaixada no topo de uma microplaca de fundo "V" de $250 \mu \mathrm{L}$ de polipropileno. Após centrifugação a $3.200 \times \mathrm{g}$ por 4 min. à temperatura ambiente, removeu-se e descartou-se o filtro millipore. Ao material filtrado acrescentou-se $110 \mu \mathrm{L}$ de isopropanol e misturou-se por inversão. Centrifugou-se a $3.200 \times \mathrm{g}$ por $45 \mathrm{~min}$. e, em seguida, descartou-se 0 sobrenadante por inversão. Adicionou-se ao pellet $200 \mu \mathrm{L}$ de etanol $70 \%$, centrifugou-se a $3.200 \times \mathrm{g}$ por $5 \mathrm{~min}$. descartando-se o sobrenadante em seguida. Após a secagem do pellet à temperatura ambiente por 60 min., este foi ressuspendido em $40 \mu \mathrm{L}$ de água Milli-Q.

A qualidade e concentração dos clones obtidos foram avaliadas em gel de agarose $0,8 \%$, comparando-se o resultado obtido com o padrão pGEM4Z (40 $\mathrm{ng} / \mu \mathrm{L})$.

\subsection{PCR da mini-preparação}

Diluições (1 $\mu \mathrm{L}$ sem diluição, 1:1, 1:10) de DNA resultante da minipreparação plasmidial foram utilizadas na reação em cadeia da polimerase (PCR) para verificação do sucesso da clonagem e tamanho dos insertos. Para cada reação foram utilizadas alíquotas das diluições às quais foram adicionados $23 \mu \mathrm{L}$ de um mix de reação, preparado com os seguintes reagentes: $2,5 \mu \mathrm{L}$ de tampão 1x (50mM KCl, 10mM Tris- $\mathrm{HCl}, \mathrm{pH} 9,0,0,1 \%$ Triton X-100), 1,5 $\mu \mathrm{L}$ de $\mathrm{MgCl}_{2} 25 \mathrm{mM}, 0,5 \mu \mathrm{L}$ de dNTP $10 \mathrm{mM}, 1,0 \mu \mathrm{L}$ dos primers M13 direto (5'- 
GTAAAACGACGGCCAGT-3') e reverso (5'-AACAGCTATGACCATG-3') a 3,2 pmoles/ $\mu \mathrm{L}$. Foi feita a desnaturação por 4 min. a $96{ }^{\circ} \mathrm{C}$ e, as condições de anelamento e extensão estabelecidas nestas reações foram: $50^{\circ} \mathrm{C} / 1 \mathrm{~min}$. e 72 ${ }^{\circ} \mathrm{C} / 5$ min., respectivamente, em um total de 35 ciclos. Os produtos da PCR foram aplicados em um gel de agarose $1 \%$ para verificação da existência e do tamanho dos insertos clonados.

\subsection{Seqüenciamento}

A reação de seqüenciamento foi realizada de acordo com as especificações do DYEnamic Terminator Cycle Sequencing Kit for MegaBACE. O primer T7 foi utilizado como iniciador para a enzima Thermo Sequenase II DNA Polymerase, anelando-se próximo à região 5' do inserto no plasmídio PSPORT 1. Os reagentes utilizados para a reação de seqüenciamento foram os seguintes: DNA (300ng); 0,5 $\mu \mathrm{L}$ de primer T7 [5'-TAATACGACTCATATAGGG3' (5 pmoles/ $\mu \mathrm{L})$ ] e $4 \mu \mathrm{L}$ de Dyenamic ET terminator sequencing premix, em um volume final de $10 \mu \mathrm{L}$. A reação compreendeu os seguintes passos: desnaturação por $20 \mathrm{seg}$. a $95^{\circ} \mathrm{C}$ e as condições de anelamento e extensão foram $50^{\circ} \mathrm{C} / 15 \mathrm{seg}$. e $60^{\circ} \mathrm{C} / 1 \mathrm{~min}$., respectivamente, em um total de 30 ciclos. O produto foi visualizado em gel de agarose 1\%, corado em solução de brometo de etídeo $0,5 \mathrm{mg} / \mathrm{mL}$.

\subsection{Purificação da reação de seqüenciamento}

Para a purificação da reação de seqüenciamento foi adicionado $1 \mu \mathrm{L}$ de acetato de amônio 7,5 M seguido de 2,5 volumes de etanol absoluto. Foram feitas a homogeneização e incubação da reação no escuro por 30 min. seguida por centrifugação a 3.100 x g por 30 min. e remoção do sobrenadante. Ao 
material precipitado foram adicionados $150 \mu \mathrm{L}$ de etanol $70 \%$, em seguida centrifugou-se a $3.100 \times \mathrm{g}$ por $10 \mathrm{~min}$. e removeu-se o sobrenadante. O pellet foi desidratado à temperatura ambiente por $30 \mathrm{~min}$. e o material foi ressuspendido em $10 \mu \mathrm{L}$ de loading solution (formamida 70\%, EDTA $1 \mathrm{mM}$ ). A eletroforese foi realizada no seqüenciador MegaBACE 1000 (Amersham biosciences) sendo que as condições de injeção das amostras foram $2 \mathrm{Kv}$ por 60 segundos, seguindo-se a eletroforese a 9Kv por 100 minutos.

\subsection{Análise das seqüências}

Os cromatogramas gerados no seqüenciamento dos clones foram utilizados para a análise dos dados em programas de bioinformática. Os programas utilizados foram Phred/Cap3/Consed (Ewing \& Green, 1998; Huang \& Madan, 1999; Gordon et al, 1998) que avaliaram as seqüências quanto à qualidade de bases, substituíram as seqüências de vetor, adaptador e poli(A) e realizaram a montagem dos contigs, respectivamente. As análises de bioinformática geram alguns termos que foram definidos abaixo:

Read - Seqüência de bases de nucleotídeos.

Clusterização - Processo de agrupamento dos reads em contigs.

Contigs - Agrupamento de várias EST mediante a sobreposição das bases, de acordo com os critérios do programa Cap3 (similaridade de 30 pb com identidade de 90\%).

Singletons - Seqüências únicas que não entram na formação dos contigs. 


\subsubsection{Análise de qualidade de seqüências (Phred)}

A análise inicial foi realizada pelo programa Phred que confere um valor de qualidade para cada base seqüenciada. Este programa reconhece a seqüência de nucleotídeos a partir do arquivo de dados brutos do seqüenciador, atribui valores de qualidade às bases constituintes da seqüência nucleotídica e gera arquivos de saída contendo os valores de qualidade. Para as seqüências geradas no estudo foram considerados apenas os reads com mais de 200 bases com qualidade superior a 20 (um erro a cada 100 bases seqüenciadas). As seqüências que não atingiram esse parâmetro foram retiradas da análise. Juntamente da análise de qualidade das bases foi utilizado o programa Cross_match para a substituição das regiões correspondentes a seqüências de vetor, adaptadores das extremidades dos insertos e caudas poli(A). Este programa faz a comparação da seqüência desejada com um arquivo de seqüências de vetores e, onde o programa encontrar similaridade entre as seqüências irá mascarar (acrescentando letras $X$ ) a seqüência desejada. Desta maneira, os nucleotídeos das seqüências de entrada similares a regiões de vetores de clonagem serão alterados para $X$ e não atrapalharão os processos posteriores de análise computacional (Prosdocimi et al., 2002).

\subsubsection{Clusterização (Cap3)}

As seqüências selecionadas a partir dos parâmetros de qualidade estabelecidos (200 bases com qualidade Phred superior a 20) foram submetidas a clusterização pelo programa Cap3. Este programa permitiu a montagem dos contigs, onde os reads referentes a uma mesma seqüência consenso foram alinhados por regiões com alta qualidade de bases. 


\subsubsection{Relatórios}

Foram gerados os seguintes relatórios das bibliotecas seqüenciadas:

Relatório de qualidade

- Número de reads

- Número de bases

- Número de bases com qualidade $>20$

- Número de bases com qualidade $>30$

- Reads com mais de 400 bases com qualidade $>20$

\section{$\underline{\text { Relatório Geral }}$}

- Número total de reads

- Número total de reads em contigs

- Número total de contigs

- Número total de singles

- Índice de novidade - Calculado em função do número de contigs e singletons de cada biblioteca pelo número total de reads válidos.

\subsubsection{Blastx}

Uma vez obtidos os dados do seqüenciamento das moléculas de cDNA é preciso identificar cada uma das seqüências produzidas. As seqüências dos contigs e dos singletons válidos foram comparadas às depositadas no GenBank (Benson, et al., 1999), utilizando-se o programa Blastx (Altschul et al., 1990) para identificar as seqüências pelo grau de similaridade entre elas. 


\subsubsection{Categorização das seqüências}

Após a identificação dos genes expressos na musculatura peitoral das duas linhagens estudadas, os genes encontrados foram divididos em categorias de acordo com suas funções. Optou-se pela categorização utilizada pelo TIGR/EGAD (www.tigr.org). Os genes encontrados foram divididos nas seguintes categorias:

Associadas a tumor - Nesta categoria foram incluídas proteínas associadas ao processo de oncogênese.

Expressão gênica - Esta categoria inclui proteínas relacionadas aos processos de transcrição e tradução de genes.

Hipotéticas conservadas - Foram agrupadas nesta categoria proteínas identificadas em outras espécies, mas sem função definida.

Low Hits - Seqüências que apresentaram baixa similaridade ( $E$ value superior a $\left.10^{-5}\right)$.

Metabolismo - Foram incluídas nesta categoria, proteínas associadas ao metabolismo geral do organismo.

No hit - Proteínas que não apresentaram similaridade com as seqüências dos bancos de dados utilizados para a análise.

Proteína estrutural - Foram agrupadas nesta categoria proteínas relacionadas à sustentação dos tecidos. 
Proteína muscular - Esta categoria foi criada para agrupar exclusivamente as proteínas músculo-específicas.

Proteína ribossomal - As proteínas ribossomais foram agrupadas nesta categoria.

Proteína transportadora - Foram agrupadas nesta categoria as hemoglobinas e outras proteínas envolvidas com transporte celular.

Outras - Esta categoria foi criada para agrupar proteínas que posteriormente poderiam ser utilizadas nas análises de expressão gênica. Estão incluídas: Desenvolvimento, Diferenciação celular, Células de defesa, Divisão celular, Estrutura celular, Fator de crescimento, Fator de transcrição, Matriz extracelular, Morte celular, Proliferação celular, Proteínas do citoesqueleto, Proteína nuclear.

Não classificadas - Proteínas não associadas a nenhuma das categorias adotadas, foram agrupadas nesta categoria.

\subsection{Análise de expressão gênica}

Para as análises de expressão gênica foram analisados os fatores miogênicos da família MyoD: MyoD, miogenina e MRF4; além de Pax-3 e miostatina ou GDF-8 (fator de crescimento e diferenciação-8). Os fatores miogênicos, bem como Pax-3, foram escolhidos por exercerem funções reconhecidas no processo de formação e/ou maturação da fibra muscular esquelética. Já a miostatina foi escolhida por se tratar de um importante inibidor de musculatura. 


\subsubsection{Incubação dos ovos e coleta dos tecidos}

A incubação dos ovos e coleta de tecidos foi realizada nas mesmas condições descritas no item 3.1, sendo as amostras de tecido coletadas do músculo pectoralis (Figura 13). Os tecidos coletados e imediatamente congelados em nitrogênio líquido foram utilizados posteriormente para extração de RNA total.

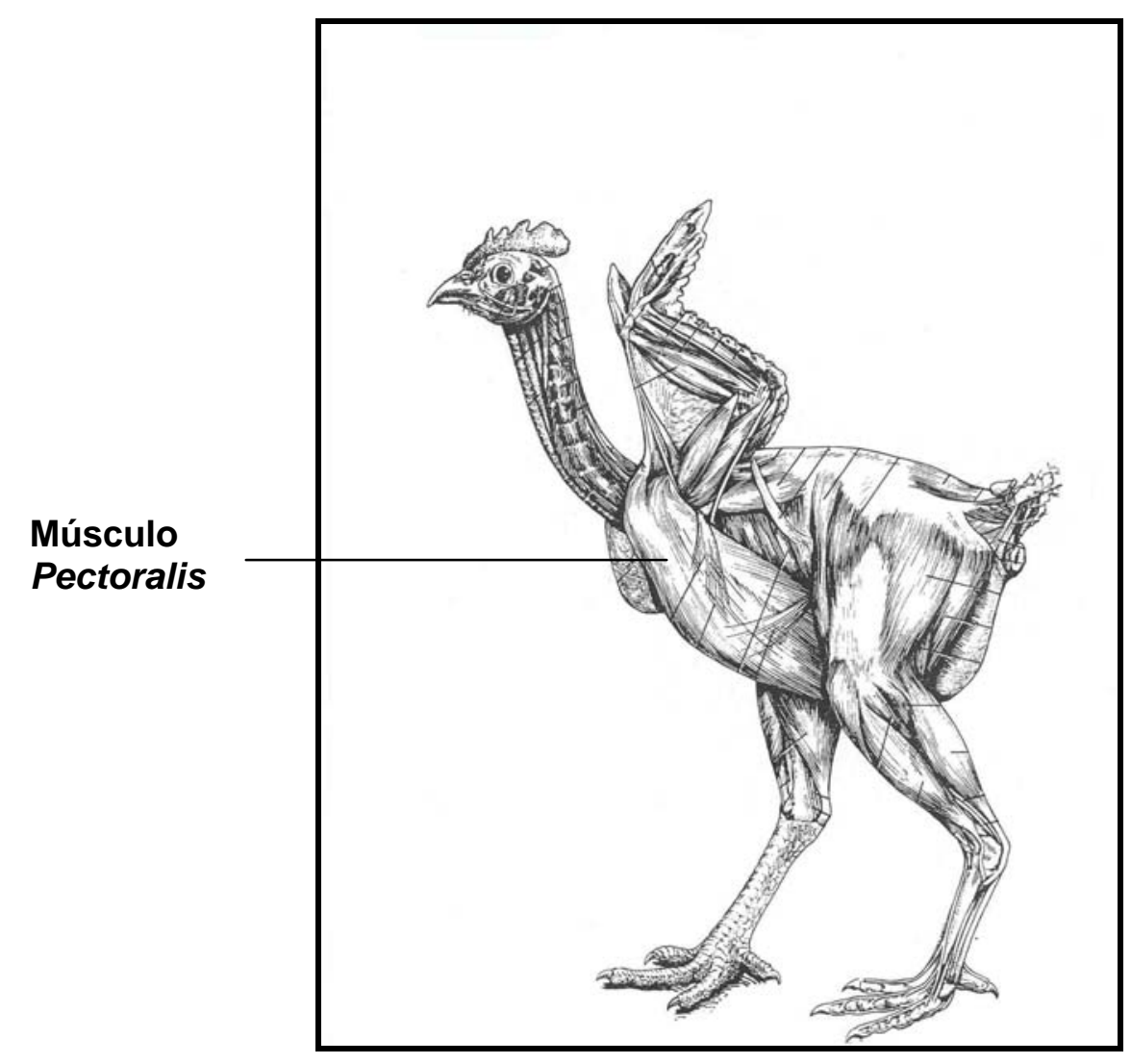

Figura 13 - Representação do músculo (Pectoralis) utilizado nas análises de expressão gênica

Fonte: adaptada de Ghetie et al. (1981) 


\subsubsection{Extração de RNA total e síntese de cDNA}

O RNA total foi isolado dos tecidos seguindo-se metodologia descrita por Chomczynski \& Sacchi (1987), conforme descrito no item 3.1.2.

A síntese de cDNA foi feita com emprego do Kit SuperScript First-Strand Synthesis System for RT-PCR (Invitrogen). Os cDNAs foram sintetizados a partir de $5 \mu \mathrm{g}$ de RNA total das amostras de tecido, $1 \mu \mathrm{L}$ de primer oligo (dT) 0,5 $\mu \mathrm{g} / \mu \mathrm{L} ; 1 \mu \mathrm{L}$ de dNTP mix $10 \mathrm{mM}$; após incubação a $65^{\circ} \mathrm{C}$ por 5 minutos, a reação foi resfriada em gelo por 1 minuto. Ao serem retiradas do gelo as amostras receberam $2 \mu \mathrm{L}$ de Buffer RT 10X; $4 \mu \mathrm{L}$ de $\mathrm{MgCl}_{2} 25 \mathrm{mM} ; 2 \mu \mathrm{L}$ de DTT $0,1 \mathrm{M}$ e $1 \mu \mathrm{L}$ de RNase OUT (40 u/ $\mu \mathrm{L})$ em um volume final de $20 \mu \mathrm{L}$. A reação foi incubada a $42{ }^{\circ} \mathrm{C}$ por 2 minutos e, posteriormente, foram adicionadas 50 unidades da enzima Superscript II RT (Invitrogen). A transcrição reversa foi feita a $42^{\circ} \mathrm{C}$ por 50 minutos, procedendo-se à inativação da enzima a $70^{\circ} \mathrm{C}$ durante 15 minutos. Para remover o RNA molde da molécula híbrida cDNA:RNA foi feita digestão com 2 unidades de RNase $\mathrm{H}$ por 20 minutos a $37^{\circ} \mathrm{C}$.

\subsubsection{PCR em tempo real}

A RT-PCR em tempo real é uma técnica rápida e acurada que permite a quantificação dos produtos da PCR em tempo real, é sensível para quantificar os produtos na fase exponencial da reação. Para as reações de PCR em tempo real deste trabalho utilizou-se o Kit Light Cycler - Fast Start DNA Master SYBR Green I (Roche). Para a preparação do Master mix em tubos de 0,5 mL, adicionam-se os seguintes reagentes: 0,4 $\mu \mathrm{L}$ de $\mathrm{MgCl}_{2}(25 \mathrm{mM}), 2 \mu \mathrm{L}$ dos primers (2 pmoles $/ \mu \mathrm{L}$ ) direto e reverso, $2 \mu \mathrm{L}$ de LightCycler - Fast Start Reaction Mix SYBR Green I (Fast Start Taq DNA polimerase, reaction buffer, dNTP mix, SYBR Green I). As reações foram preparadas adicionando-se $18 \mu \mathrm{L}$ 
de master mix em cada capilar (pré-resfriado a $4{ }^{\circ} \mathrm{C}$ ) seguidos de $2 \mu \mathrm{L}$ de cDNA em cada reação. Seguindo-se de uma breve centrifugação dos capilares a 700xg por 5 segundos e colocação dos capilares no equipamento LigthCycler (Roche).

Os primers empregados nas análises de PCR em tempo real para cada um dos genes analisados estão descritos na Tabela 2. Os primers para $\beta$ actina, MyoD, Pax-3 e miostatina foram descritos por Álvares, 2001. Na Tabela 3 estão descritas as condições de PCR em tempo real para cada um dos genes analisados.

Tabela 2. Primers empregados nas PCRs

\begin{tabular}{llc}
\hline \multicolumn{1}{c}{ Gene } & \multicolumn{1}{c}{ Primers } & $\begin{array}{c}\text { Tamanho do produto da } \\
\text { PCR }(\mathbf{p b})\end{array}$ \\
\hline MyoD & D - 5' TAC CCA GTG CTG GAG CAC TA - 3' & 471 \\
& R - 5' GTC TTG GAG CTT GGC TGA AC - 3' & \\
MRF4 & D - 5'AGG CTG GAT CAG CAG GAC AA - 3' & 223 \\
& R - 5'ATC GTG GAC AGC ATT TCC TC'- 3' & 508 \\
Miogenina & D - 5'AGG CTG AAG AAG GTG AAC GA-3' & \\
& R - 5'ATT ACC CCT CCG ACA CTG TG - 3' & \\
Pax-3 & D - 5' TGG AGC CCA CCA CCA CTG TC - 3' & 427 \\
& R - 5' AAC ACC AGC TTA ACT TGA AG - 3' & \\
Miostatina & D - 5' AGT AGC GAT GGC TCT TTG GA - 3' & \\
& R - 5' CTG GGA ATG TGA CAG CAA GA - 3' & \\
\multirow{3}{*}{-actina } & D - 5' AAT GAG AGG TTC AGG TGC CC - 3' & \\
& R - 5' ATC ACA GGG GTG TGG GTG TT - 3' & \\
\hline
\end{tabular}


Tabela 3. Condições das reações de PCR para os genes analisados

\begin{tabular}{lllllc}
\hline \multicolumn{1}{c}{ Gene } & Pré-incubação & Desnaturação & Anelamento & Extensão & $\begin{array}{c}\mathrm{N}^{0} \mathrm{de} \\
\text { ciclos }\end{array}$ \\
\hline MyoD & $95^{\circ} \mathrm{C} / 10 \mathrm{~min}$. & $95^{\circ} \mathrm{C} / 10 \mathrm{seg}$. & $57^{\circ} \mathrm{C} / 10 \mathrm{seg}$. & $72^{\circ} \mathrm{C} / 19 \mathrm{seg}$. & 50 \\
Miogenina & $95^{\circ} \mathrm{C} / 10 \mathrm{~min}$. & $95^{\circ} \mathrm{C} / 10 \mathrm{seg}$. & $55^{\circ} \mathrm{C} / 5 \mathrm{seg}$. & $72^{\circ} \mathrm{C} / 20 \mathrm{seg}$. & 50 \\
MRF4 & $95^{\circ} \mathrm{C} / 10 \mathrm{~min}$. & $95^{\circ} \mathrm{C} / 10 \mathrm{seg}$. & $55^{\circ} \mathrm{C} / 5 \mathrm{seg}$. & $72^{\circ} \mathrm{C} / 10 \mathrm{seg}$. & 50 \\
Pax-3 & $95^{\circ} \mathrm{C} / 10 \mathrm{~min}$. & $95^{\circ} \mathrm{C} / 10 \mathrm{seg}$. & $55^{\circ} \mathrm{C} / 10 \mathrm{seg}$. & $72^{\circ} \mathrm{C} / 10 \mathrm{seg}$. & 50 \\
Miostatina & $95^{\circ} \mathrm{C} / 10 \mathrm{~min}$. & $95^{\circ} \mathrm{C} / 10 \mathrm{seg}$. & $62^{\circ} \mathrm{C} / 5 \mathrm{seg}$. & $72^{\circ} \mathrm{C} / 18 \mathrm{seg}$. & 50 \\
$\beta$-actina & $95^{\circ} \mathrm{C} / 10 \mathrm{~min}$. & $95^{\circ} \mathrm{C} / 10 \mathrm{seg}$. & $55^{\circ} \mathrm{C} / 10 \mathrm{seg}$. & $72^{\circ} \mathrm{C} / 20 \mathrm{seg}$. & 50 \\
\hline
\end{tabular}

Juntamente com a amplificação das amostras em tempo real, o equipamento utilizado fornece uma curva de melting para cada uma das amostras amplificadas. Esse dado permite verificar a temperatura de desnaturação dos produtos da reação de PCR, podendo-se diferenciar entre os produtos amplificados e os dímeros de primers e produtos inespecíficos. As temperaturas de melting para os genes analisados neste estudo foram em torno de: $90,1{ }^{\circ} \mathrm{C}$ para MyoD, $93,8{ }^{\circ} \mathrm{C}$ para miogenina, $93,6{ }^{\circ} \mathrm{C}$ para MRF4, 87,7 ${ }^{\circ} \mathrm{C}$ para Pax-3, $84,3^{\circ} \mathrm{C}$ para miostatina e $86,9^{\circ} \mathrm{C}$ para $\beta$-actina.

O método escolhido para a quantificação dos resultados foi o método de quantificação relativa, uma vez que não é necessário saber o número absoluto de cópias de cada gene e sim a diferença de expressão entre as linhagens estudadas. Este método envolve a quantificação do gene de interesse em relação a um gene controle, um gene constitutivo, que neste trabalho foi a $\beta$ actina (Giulietti et al. 2001, Livak \& Schmittgen, 2001). 


\section{RESULTADOS E DISCUSSÃO}

\subsection{Parâmetros de peso}

Com base nos resultados apresentados na Tabela 4 pode-se observar uma pequena diminuição no peso dos ovos $(p<0,01)$ das duas linhagens durante o desenvolvimento embrionário (entre 9 e 17 dias de incubação). Porém, a linhagem de corte $(\mathrm{TT})$ apresentou ovos mais pesados $(\mathrm{P}<0.01)$ em relação à linhagem de postura. Em relação ao peso corporal, as linhagens (corte, TT e postura $\mathrm{CC}$ ) apresentaram perfis de crescimento ao longo do desenvolvimento embrionário, bem como na fase pós-eclosão, variando de 1,5 e 1,3 g aos 9 dias de incubação, para 51,9 e 39,1g, respectivamente, à eclosão e atingindo pesos finais de 778 e $218 \mathrm{~g}$ aos 21 dias de idade. Em adição, o músculo peitoral apresentou pesos maiores $(p<0,05)$ nas aves da linhagem de corte em relação às de postura, principalmente aos 21 dias de idade onde 0 peso foi em torno de seis vezes maior na linhagem de corte. Tomados juntos, esses dados denotam um crescimento acelerado, bem como uma maior deposição de massa muscular na linhagem de corte em relação à de postura. 
Tabela 4. Médias e desvios-padrão dos pesos de ovos (Povo), peso animal (Panimal) e peso do músculo peitoral (Pmúsculo) nas fases: embrionária e pós-eclosão

\begin{tabular}{lccccccc}
\hline \multirow{2}{*}{ Idade } & $\mathrm{n}$ & \multicolumn{2}{c}{ Povo (g) } & \multicolumn{2}{c}{ Panimal (g) } & \multicolumn{2}{c}{ Pmúsculo (g) } \\
\hline E9 & 10 & $70,49^{\star \star \star} \pm 1,3$ & $59,33^{\star \star \star} \pm 1,3$ & $1,53^{\star} \pm 0,04$ & $1,39^{\star} \pm 0,04$ & - & TT \\
E17 & 10 & $64,86^{\star \star \star} \pm 1,7$ & $52,38^{\star \star \star} \pm 1,7$ & $22,17^{\star \star} \pm 0,9$ & $17,71^{\star \star} \pm 0,9$ & $0,282^{\star \star \star} \pm 0,01$ & $0,193^{\star \star \star} \pm 0,01$ \\
D1 & 10 & - & - & $51,97^{\star \star \star} \pm 1,5$ & $39,19^{\star \star \star} \pm 1,5$ & $0,449^{\star \star} \pm 0,02$ & $0,317^{\star \star} \pm 0,02$ \\
D21 & 10 & - & - & $778,5^{\star \star \star} \pm 21,3$ & $218,6^{\star \star \star} \pm 21,3$ & $42,48^{\star \star \star} \pm 1,4$ & $7,73^{\star \star \star} \pm 1,4$ \\
\hline
\end{tabular}

E9: 9dias de incubação; E17: 17dias de incubação; D1: 1 dia de idade; D21: 21 dias de idade; TT: linhagem de corte; CC: linhagem de postura. ${ }^{* \star *} p<0,01$; ${ }^{* \star} p<0,05$; ${ }^{*} p<0,10$.

\subsection{Extração de RNA total e seleção do RNA mensageiro}

A eletroforese em gel de agarose $1 \%$ permitiu identificar a integridade das amostras de RNA total (Figura 14). A integridade do material é avaliada pela presença das bandas estruturais de RNA ribossômico (28S, 18S e 5,8 S). Após a verificação da qualidade do RNA total, a população de mRNA foi selecionada, quantificada e diluída para uma concentração de $1 \mu \mathrm{g} / \mu \mathrm{l}$.

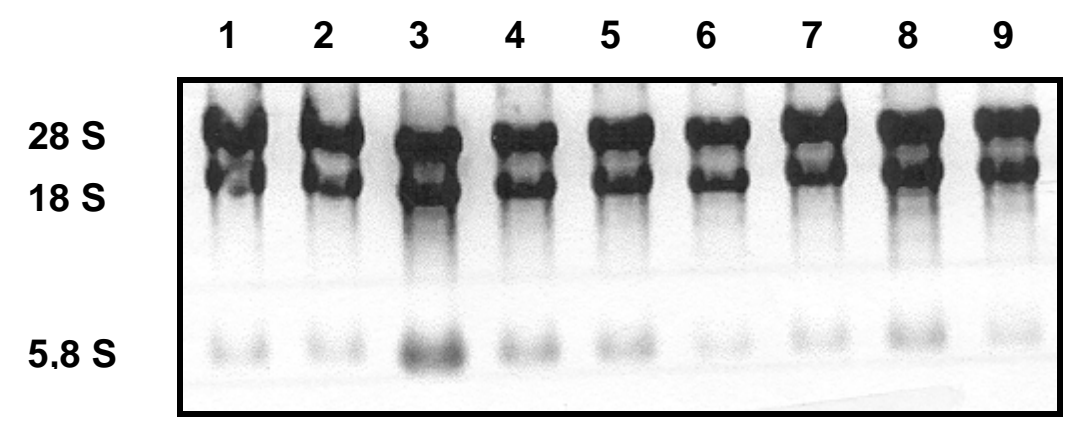

Figura 14 - Fotografia de gel de agarose 1\% para verificação da qualidade do RNA total. As canaletas de 1 a 9 correspondem ao RNA extraído de amostras da musculatura peitoral 


\subsection{Construção da biblioteca de cDNA}

A amostra de cDNA dupla fita sintetizada não foi quantificada devido à escassez de material. Conforme descrito pelos fabricantes do kit, o material deveria ter sido sintetizado utilizando-se material radioativo $\left(\mathrm{P}^{32}\right)$, o que permitiria uma quantificação precisa. No entanto, como o laboratório não possuía certificado para trabalhar com material radioativo, a síntese de cDNA foi feita sem o uso do mesmo. Por este motivo, a eficiência do processo de construção da biblioteca somente foi confirmada após o resultado da clonagem em vetor pSPORT1.

O número de frações selecionadas para a reação de ligação dos insertos ao vetor foi determinado de maneira a garantir uma concentração suficiente para a realização desta reação (cerca de $10 \mathrm{ng} / \mu \mathrm{L}$ ). Para isso, três frações representando os insertos maiores, foram selecionadas e concentradas em Speed Vac para a obtenção de uma concentração ideal de cDNA.

\subsection{Avaliação do tamanho dos insertos clonados}

Para a verificação do tamanho dos insertos clonados, realizou-se PCR com DNA proveniente da mini-preparação. Os produtos dessa reação foram visualizados em gel de agarose 1\%, como pode ser verificado na Figura 15. Constatou-se que os tamanhos dos insertos utilizados para a reação de PCR da mini-preparação estavam entre 1.0 e $1.6 \mathrm{~kb}$. 


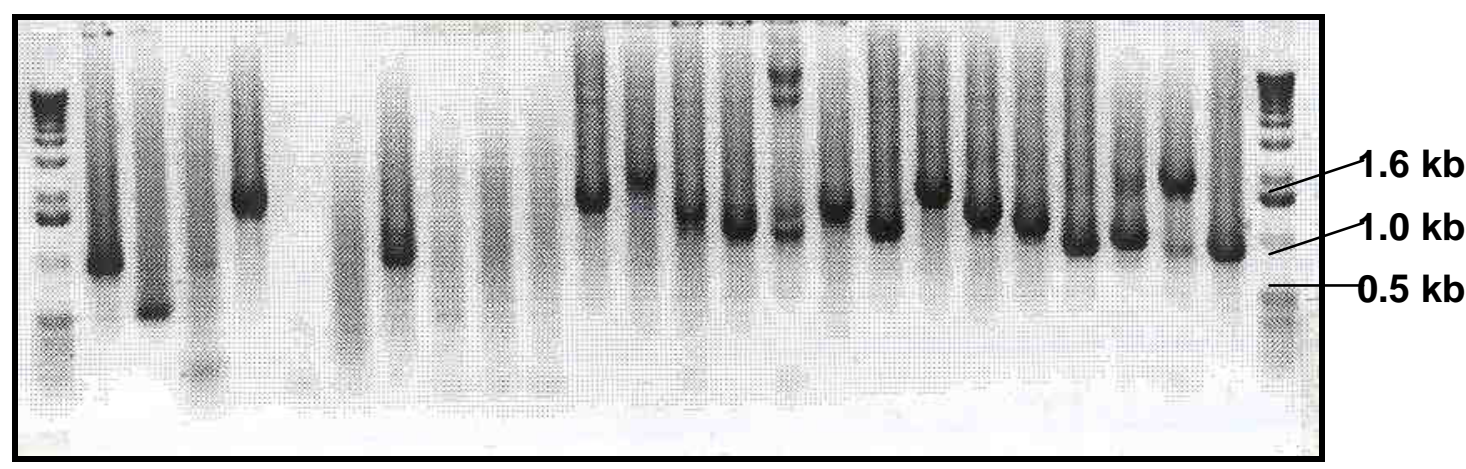

Figura 15 - Fotografia de gel de agarose 1\% para verificação do tamanho dos insertos clonados. As canaletas correspondem a: 1 e 26- $1 \mathrm{~Kb}$ ladder - Invitrogen (marcador de peso molecular); 2-25- DNA proveniente da reação de PCR da mini-preparação plasmidial

\subsubsection{Análise das ESTs}

Um total de 8928 EST foram seqüenciadas da extremidade 5' dos insertos de cDNA (Figura16) Após análise de qualidade, 6247 foram selecionadas como válidas segundo os parâmetros estabelecidos (mínimo de 200 bases com qualidade Phred superior a 20), o que corresponde a um índice de sucesso de $69,9 \%$. 


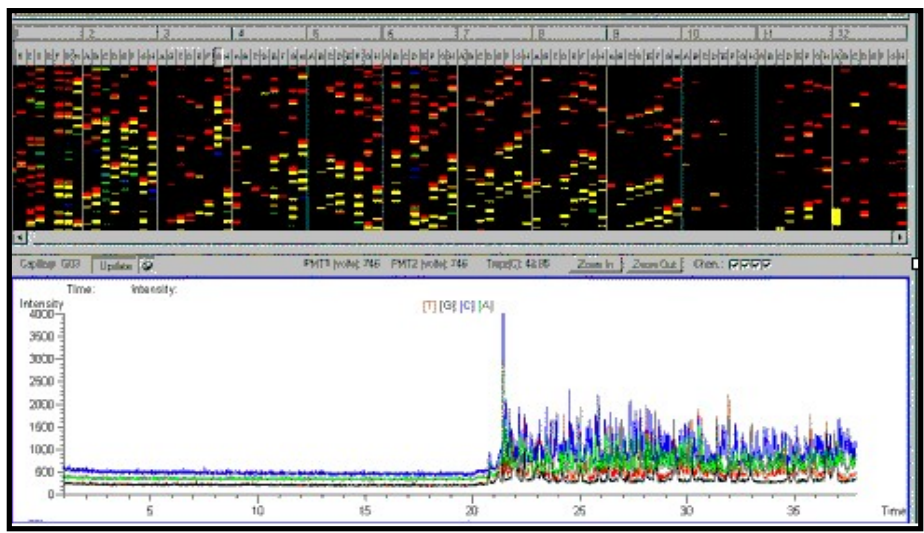

Figura 16 - Visualização de eletroforese de uma reação de seqüenciamento no equipamento MegaBACE 1000

O processo de clusterização foi realizado para as três bibliotecas isoladamente e também em conjunto (EB1, EB2 e CB1). Os resultados da clusterização conjunta foram descritos na Tabela 5 e na Tabela 6 encontram-se os dados provenientes da análise individual.

Tabela 5. Resultados da clusterização conjunta das bibliotecas (EB1, EB2 e CB1)

\begin{tabular}{lc}
\hline Número total de reads válidos & $\mathbf{6 2 4 7}$ \\
\hline Número de contigs & 716 \\
Número de reads em contigs & 3479 \\
Número de singletons & 2768 \\
Número de contigs + singletons & $\mathbf{3 4 8 4}$ \\
\hline
\end{tabular}


Tabela 6. Resultados da análise de clusterização por biblioteca

\begin{tabular}{lccc}
\hline & EB1 & CB1 & EB2 \\
\hline Número de contigs & 229 & 257 & 180 \\
Número de singletons & 1110 & 804 & 678 \\
Número de contigs + singletons & 1339 & 1061 & 858 \\
\hline
\end{tabular}

A análise de clusterização conjunta revelou um índice de $55,7 \%$ de novidade para o banco construído. Esse índice fornece informação em relação à redundância, mostrando que a cada 10 seqüências geradas pelo menos cinco representavam seqüências novas para o banco. Para a biblioteca EB1 o índice foi calculado em 64,9\%; para EB2 $71,5 \%$ e para CB1 foi de $46,8 \%$. Estes índices revelaram que as bibliotecas da fase embrionária contribuíram com um maior número de seqüências novas para o banco de dados de Gallus gallus em relação à biblioteca da fase pós-eclosão. Na fase embrionária há expressão de muitos genes, principalmente aqueles relacionados a desenvolvimento, enquanto na fase pós-eclosão o tecido muscular já está diferenciado. O maior índice constatado em EB2 explica-se pelo menor número de clones seqüenciados para esta biblioteca.

No gráfico da Figura 17 foram distribuídos os números de reads alinhados em contigs em relação à sua representatividade nas bibliotecas (número de reads em contigs). Na análise conjunta foi observado que cerca de $55,7 \%$ dos reads foram agrupados em contigs e que $73,8 \%$ dos contigs foram formados pelo alinhamento de até quatro reads. Contigs formados pelo alinhamento de cinco ou mais reads foram considerados neste estudo como representantes de genes altamente expressos, segundo dados publicados por Jia et al. (2002). O índice de freqüência de reads em contigs e os $26,2 \%$ de redundância são indicativos da especialização do tecido muscular nos estádios selecionados para este estudo, especialmente da biblioteca da fase pós- 
eclosão. Uma alternativa para minimizar o índice de redundância apresentado neste estudo seria a utilização de um método de normalização na construção das bibliotecas.

$\mathrm{N}^{\circ}$ de contigs

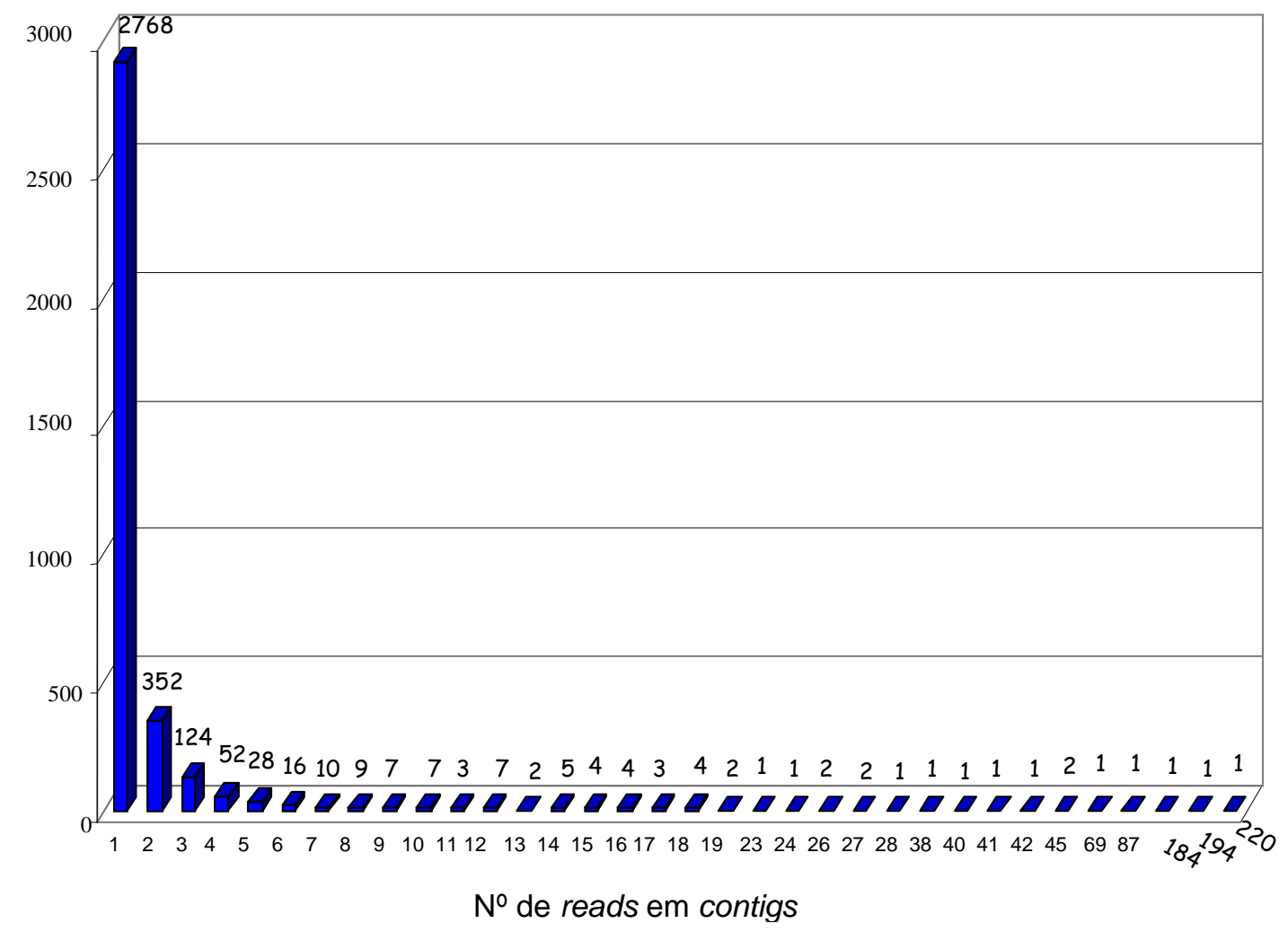

Figura 17 - Resultado da distribuição dos reads em contigs na análise conjunta das três bibliotecas (EB1, CB1 e EB2)

Dentre os genes mais expressos encontrados nas bibliotecas construídas encontram-se o precursor de alfa actina 1 que formou um contig contendo 220 reads (3,52\%) e gliceraldeído 3 fostato desidrogenase que formou 1 contig contendo 184 reads (2,94\%). Outros genes que também foram bastante expressos codificam para diferentes subunidades de citocromo c oxidade, são 
elas: subunidade 1 com contig formado por 194 reads (3,10\%), subunidade 2 com contig formado por 19 reads $(0,3 \%)$ e subunidade 3 com contig formado por 87 reads (1,39\%). Além de citocromo b com contigs formados por 26 $(0,41 \%)$ e 11 reads $(0,17 \%)$. Observou-se, portanto, que entre os contigs que representam genes mais expressos foram encontrados aqueles que codificaram para enzimas envolvidas em processos metabólicos (glicólise e ciclo do ácido cítrico), dados esperados nesta análise por representarem genes de manutenção celular.

Entre os contigs considerados representantes de genes altamente expressos nas bibliotecas analisadas também foram encontrados genes específicos de tecido muscular envolvidos no processo de contração do músculo. Entre eles, várias isoformas de miosinas: miosina regulatória de cadeia leve, isoforma 2 e miosina de cadeia leve alcalina, isoforma 1 que formaram contigs contendo 45 reads $(0,72 \%)$; miosina de cadeia pesada com contig formado por 24 reads $(0,38 \%)$ e miosina de cadeia pesada, isoforma adulta com contig formado por 9 reads $(0,14 \%)$. Outras proteínas músculo esqueléticas identificadas entre as mais expressas foram troponina $\mathrm{C}$, troponina $\mathrm{T}$ isoformas 2 e 4, troponina de cadeia $\alpha$ e calsequestrina, os quais formaram contigs contendo 38 (0,6\%), 10 (0,16\%), 16 (0,26\%), 12 (0,19\%) e $8(0,13 \%)$ reads, respectivamente. A proteína statin foi representada por um contig contendo $14(0,22 \%)$ reads. Esta proteína está associada à modulação de fatores envolvidos nos processos de proliferação e diferenciação celular. Uma outra proteína conhecida como Frizzled, um receptor de Wnt, efetor positivo de miogênese, formou um contig contendo $7(0,11 \%)$ reads.

Algumas das diferentes subunidades das proteínas ribossomais também foram encontradas entre os contigs considerados altamente expressos, formando contigs com 23 (0,37\%, subunidade S2), 19 (0,3\%, subunidade S3a), 18 (0,29\%, subunidade L7a), 15 (0,24\%, subunidades L8 e L10), 12 (0,19\%, subunidades L10a e SA), 10 (0,16\%, subunidades S4 e L5) e $9(0,14 \%$, subunidade L38) reads. 
Finalmente, proteínas hipotéticas conservadas e com baixas similaridades com o banco de dados (Low hits) também foram encontradas entre esses contigs. Foram identificados três contigs classificados como Low hits contendo $14(0,22 \%), 10(0,16 \%)$ e $7(0,11 \%)$ reads; e entre as proteínas hipotéticas conservadas foram formados contigs contendo $17(0,27 \%), 15$ $(0,24 \%), 12(0,19 \%)$ e $10(0,16 \%)$ reads.

\subsubsection{Categorização das ESTs}

No gráfico da Figura 18 foram distribuídos os dados da classificação das ESTs segundo sua função biológica.

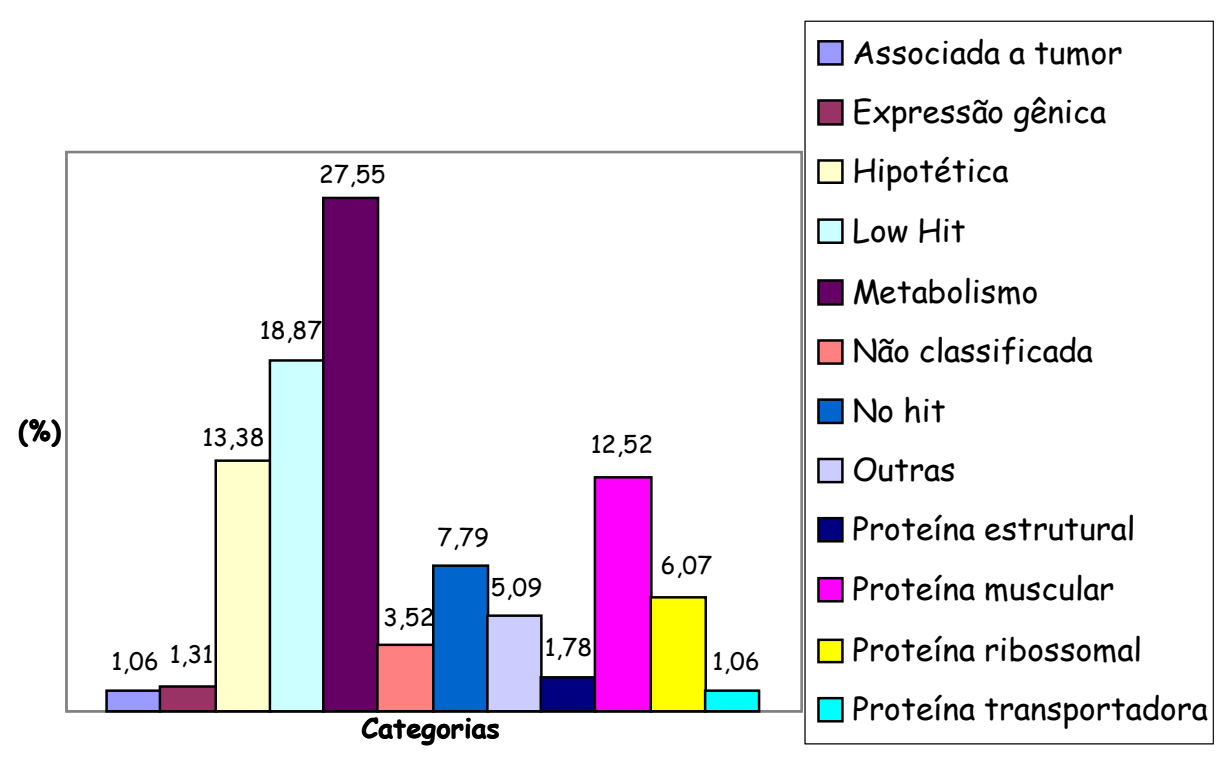

Figura 18 - Distribuição das EST em categorias (TIGR/EGAD)

Cerca de $27,55 \%$ das ESTs geradas neste estudo foram classificadas na categoria metabolismo, dado esperado por tratar-se de uma categoria que 
agrupa proteínas de manutenção celular (housekeeping genes). As categorias No hits $(7,79 \%)$ e Low hits (18,87\%) agruparam seqüências ainda não descritas no banco de dados (ftp://ftp.ncbi.nlm.nih.gov/blast/db). Esses $26,6 \%$ somados aos $13,38 \%$ de seqüências classificadas na categoria hipotéticas conservadas formam um catálogo que poderá ser utilizado para a descoberta de novos genes em tecido muscular esquelético.

\subsubsection{Análise das seqüências No hits}

As seqüências classificadas na categoria No hits são as que não apresentaram similaridade com as seqüências do banco de dados utilizados para a análise.

Para tentar identificar algumas destas seqüências foi feita uma montagem de todas elas (envolvendo as três bibliotecas) com a utilização da ferramenta de bioinformática Cap3. Do total de seqüências utilizadas, 786 não entraram na montagem e foram então comparadas as seqüências depositadas no Banco de EST de Gallus gallus (ftp://ftp.tigr.org/pub/data/tgi/Gallus gallus) com a utilização da ferramenta BLAST. Como resultado, das 786, 70 seqüências permaneceram não identificadas sendo então comparadas as do banco de EST de humanos através do BLAST (ftp://ftp.ncbi.nlm.nih.gov/blast/db). Após a análise restaram ainda 53 seqüências que não tiveram similaridade com nenhuma das seqüências depositadas.

As 53 seqüências foram então submetidas ao Banco de Gallus gallus Ensembl (http://www.ensembl.org/Gallus gallus- 22/07/2004) com o objetivo de localizá-las nos cromossomos e descartar a possibilidade de serem erros de seqüenciamento. Após a análise, sete seqüências foram descartadas por não terem sido localizadas. As 46 restantes apresentaram similaridade com a seqüência do genoma de galinha e podem representar seqüências expressas ainda não identificadas em Gallus gallus. 
Em adição, as 46 seqüências foram analisadas com a finalidade de encontrar domínios conservados de proteínas. Para tanto, as seqüências foram submetidas ao banco de dados Interpro (http://www.ebi.ac.uk/InterProScan). Para algumas das seqüências utilizadas foram encontrados domínios conservados, porém com um valor de probabilidade (E-value) baixo. Portanto, essas seqüências podem ser utilizadas em análises futuras com o objetivo de identificá-las em Gallus gallus.

\subsubsection{Categoria Outras}

Dentre as EST classificadas como outras (Figura 19) foram agrupadas as seguintes categorias: desenvolvimento $(0,3 \%)$, diferenciação celular $(0,24 \%)$, adesão celular (0,3\%), células de defesa $(0,27 \%)$, divisão celular $(0,27 \%)$, estrutura celular $(0,98 \%)$, fator de crescimento $(0,48 \%)$, fator de transcrição $(0,43 \%)$, matriz extracelular $(0,1 \%)$, morte celular $(0,18 \%)$, proliferação celular $(0,37 \%)$, proteínas do citoesqueleto $(0,19 \%)$ e proteína nuclear $(0,98 \%)$. Essa divisão mais detalhada dessas categorias foi justamente criada para facilitar a identificação de genes que posteriormente poderiam ser selecionados para terem seus perfis de expressão analisados. 


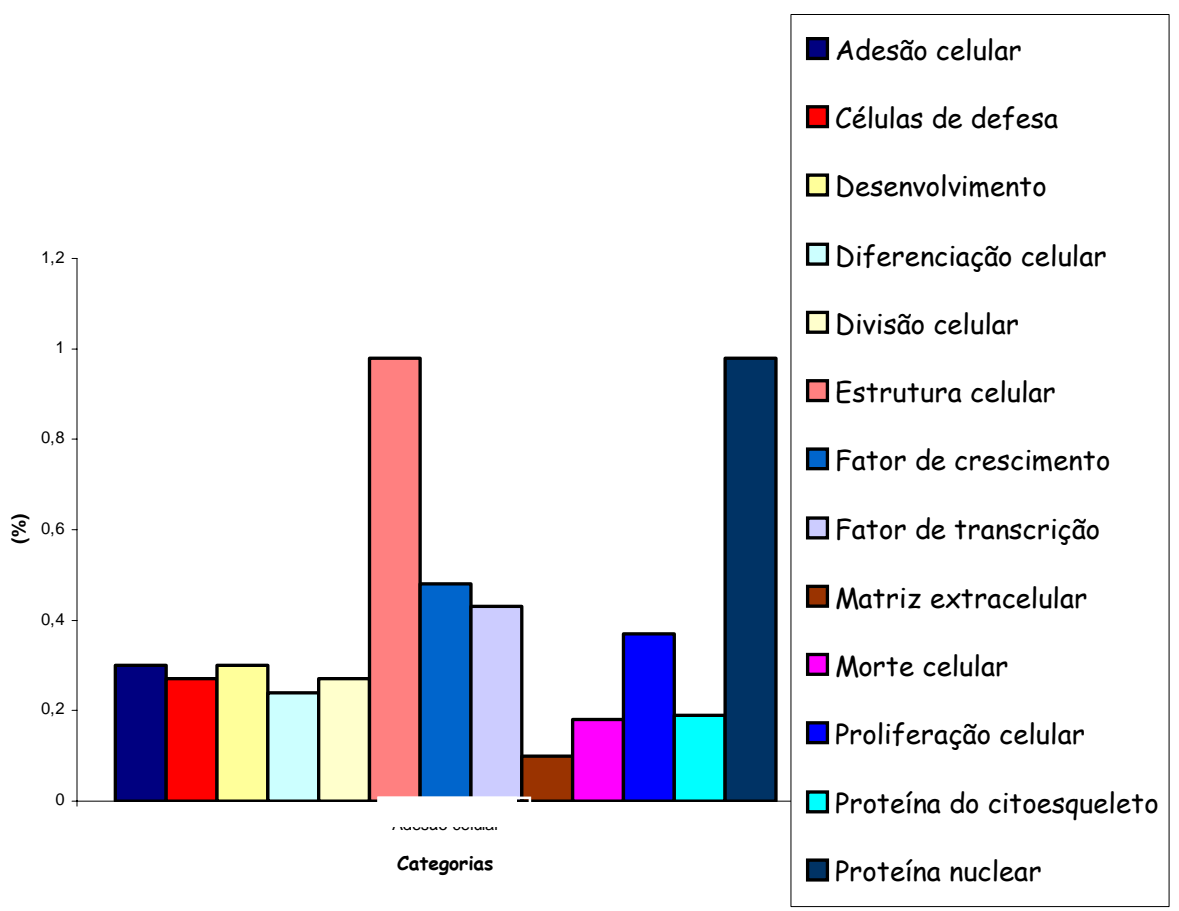

Figura 19 - Componentes da categoria Outras

Dentro da categoria desenvolvimento foram encontrados singletons representando os genes Wnt-11 e um inibidor da família MyoD. Em aves, a expressão de Wnt-11 ocorre no lábio epaxial do dermomiótomo, do qual as células irão migrar para o miótomo (Buckingham, 2001). Esses genes foram encontrados somente na biblioteca da fase embrionária da linhagem CC (postura) podendo indicar um atraso no desenvolvimento da linhagem de postura em relação à de corte (TT). Sugerindo que enquanto a linhagem de corte apresenta um número maior de genes músculo-específicos, a de postura mostra genes ainda ligados à formação da musculatura.

$\mathrm{Na}$ categoria diferenciação celular foram identificados singletons e contigs representando o gene Follistatin que tem sido descrito como regulador da expressão de miostatina (Kocamis et al., 1999). Dessa forma, torna-se um interessante candidato para estudos de expressão gênica, uma vez que esse gene foi encontrado nas bibliotecas das duas linhagens. 
Alguns fatores de crescimento como: Transforming Growth Factor, beta 3 (TGF- $\beta$ 3), proteínas de ligação aos TGFs- $\beta 1$ e 2, bem como, receptores de TGF- $\beta 2$ e Fibroblast Growth Factor (FGF) foram identificados nas bibliotecas das linhagens de corte e postura. Trata-se de fatores importantes na regulação da expressão de genes músculo-específicos (Perry \& Rudnick, 2000).

\subsubsection{Proteínas Musculares}

Várias isoformas de proteínas contráteis foram encontradas nas bibliotecas do tecido peitoral nas duas fases de desenvolvimento (embrionária e póseclosão) e nas duas linhagens (TT, corte e CC, postura) construídas para este estudo. Essas proteínas estão representadas nas Figuras 20, 21 e 22. 
Distribuição dos transcritos de proteínas musculares

TT $\square$ CC

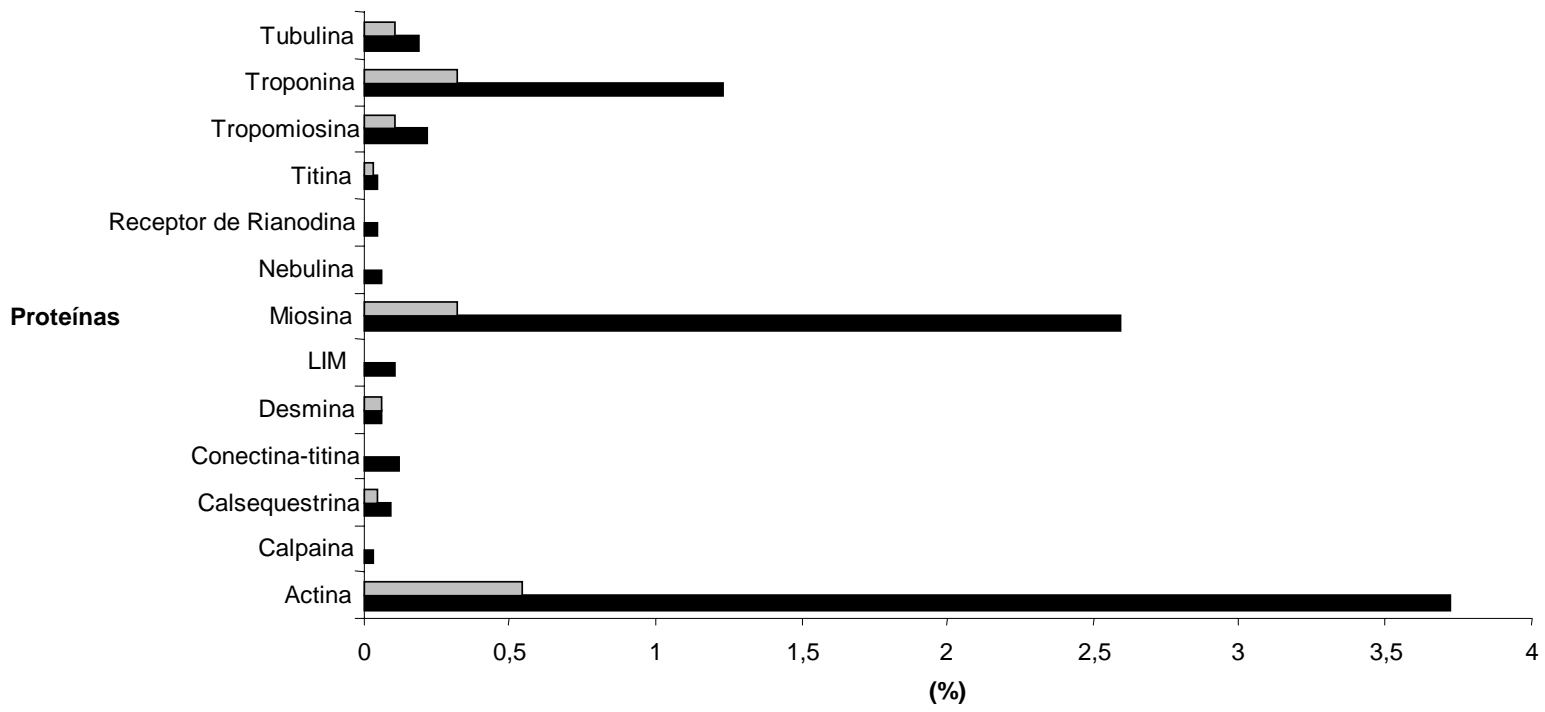

Figura 20 - Distribuição dos transcritos de proteínas musculares nas linhagens de corte (TT) e postura (CC) 


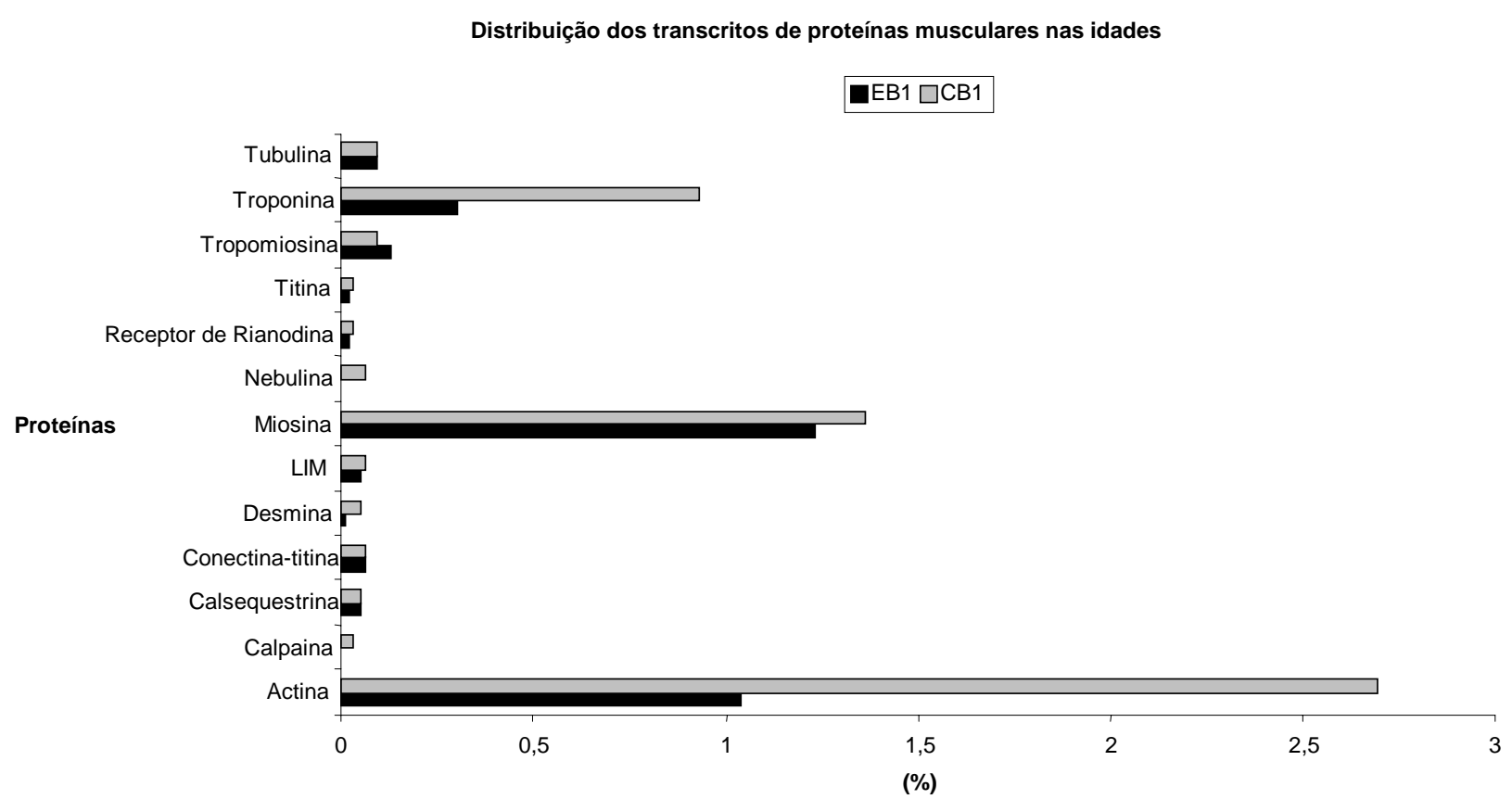

Figura 21 - Distribuição dos transcritos de proteínas musculares em duas idades: EB1 (fase embrionária, 9 e 17 dias de incubação, linhagem TT) e CB1 (fase pós-eclosão, 1 e 21 dias de idade, linhagem TT) 


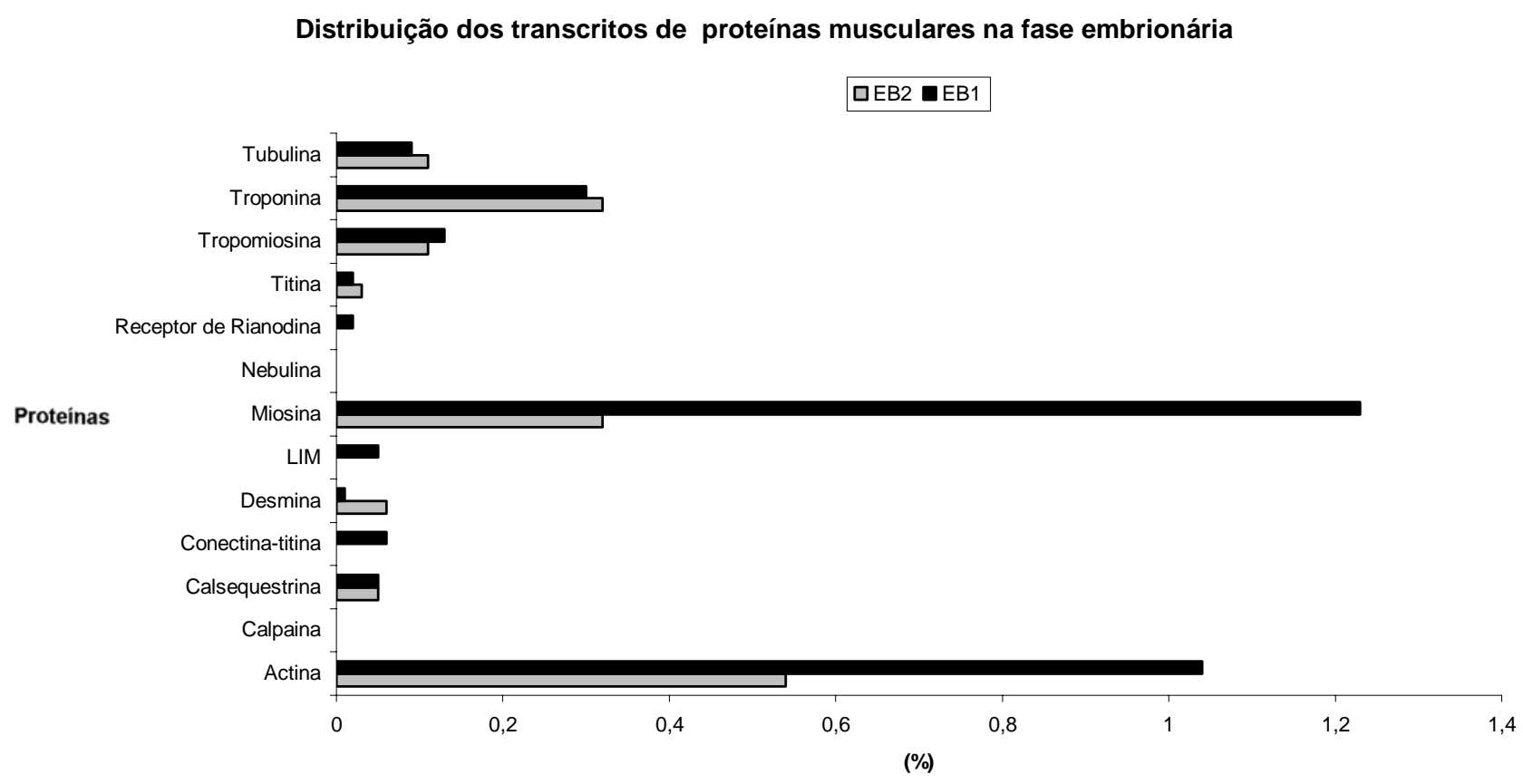

Figura 22 - Distribuição dos transcritos de proteínas musculares na fase embrionária (9 e 17 dias de incubação): EB1 (linhagem de corte, TT) e EB2 (linhagem de postura, CC)

No gráfico da Figura 20 pode-se observar que a linhagem TT foi a que apresentou um número maior de genes relacionados a proteínas músculoespecíficas em relação à linhagem CC. Na comparação feita entre as idades (Figura 21) nota-se que um número maior de proteínas musculares foi encontrado na fase pós-eclosão (biblioteca CB1, linhagem TT). Além disso, quando comparadas as duas bibliotecas da fase embrionária das duas linhagens (EB1, linhagem TT e EB2, linhagem CC) a ocorrência de proteínas músculo-específicas foi maior na linhagem TT (Figura 22). Com base nesses dados pode-se sugerir que a maturação das fibras musculares na linhagem de corte (TT) foi mais rápida em relação à linhagem de postura (CC). 
Foram encontradas várias isoformas de miosinas nas três bibliotecas deste estudo. No entanto, algumas foram encontradas somente na fase embrionária, como miosina de cadeia pesada de contração rápida isoformas 2 e 3, miosina de cadeia pesada, miosina de cadeia leve isoformas $1 \mathrm{~F}$ e 6 e miosina regulatória de cadeia leve $2 \mathrm{~A}$. Outras como miosina de cadeia pesada de contração rápida isoforma adulta, miosina de cadeia pesada $2 X$ e miosina de cadeia leve isoforma 2 foram encontradas somente na biblioteca da fase adulta. Por outro lado, algumas isoformas foram encontradas nas duas linhagens (corte e postura) e fases de desenvolvimento (embrionária e pós-eclosão): miosina de cadeia leve isoforma 1 e miosina regulatória de cadeia leve 2.

\subsection{Gene Ontology}

Além da classificação estabelecida pelo TIGR/EGAD, as seqüências geradas no presente estudo foram submetidas à classificação através do Gene Ontology. O Gene Ontology (GO) Consortium (http://www.geneontology.org) foi desenvolvido como uma nomenclatura sistemática e padronizada para a anotação de genes em vários organismos. O GO é dividido em três categorias que refletem aspectos conservados da biologia: função molecular, processos biológicos e componentes celulares. Os vocabulários contem uma estrutura hierárquica de termos designados para descrever o que o produto de um dado gene faz e onde está localizado na célula. Deste modo, os genes podem ser anotados em mais de um termo de cada ontologia, uma vez que um gene pode ter mais do que uma função, estar envolvido em uma variedade de processos biológicos, bem como desempenhar funções em vários locais na célula (Hill et al, 2001; Xie et al, 2002). Os resultados da anotação das seqüências das bibliotecas de musculatura peitoral construídas neste estudo estão sumarizados nas Tabelas 7, 8 e 9. 
Tabela 7. Resultados da anotação pelo Gene Ontology (GO) para as seqüências da biblioteca EB1

\begin{tabular}{|c|c|c|}
\hline \multicolumn{3}{|c|}{ Componente Celular - 718} \\
\hline Categoria & $\begin{array}{c}\mathrm{N}^{0} \mathrm{de} \\
\text { seqüências }\end{array}$ & $\begin{array}{c}\text { \% das } 718 \text { seqüências classificadas } \\
\text { nesse termo }\end{array}$ \\
\hline Extracelular & 45 & 6,26 \\
\hline Célula & 690 & 96,10 \\
\hline Não localizado & 39 & 5,43 \\
\hline Obsoleto & 27 & 0,37 \\
\hline Componente celular desconhecido & 69 & 9,61 \\
\hline \multicolumn{3}{|c|}{ Processo Biológico - 726} \\
\hline Categoria & $\begin{array}{l}N^{0} \text { de } \\
\text { seqüências }\end{array}$ & $\begin{array}{c}\% \text { das } 726 \text { seqüências classificadas } \\
\text { nesse termo }\end{array}$ \\
\hline Desenvolvimento & 316 & 43,52 \\
\hline Processo celular & 528 & 72,72 \\
\hline Processo biológico desconhecido & 587 & 80,85 \\
\hline Processo fisiológico & 71 & 9,77 \\
\hline Ciclo de vida viral & 1 & 0,13 \\
\hline Comportamento & 5 & 0,68 \\
\hline Obsoleto & 85 & 11,70 \\
\hline \multicolumn{3}{|c|}{ Função Molecular - 733} \\
\hline Categoria & $\begin{array}{c}\mathrm{N}^{0} \mathrm{de} \\
\text { seqüências }\end{array}$ & $\begin{array}{c}\% \text { das } 733 \text { seqüências classificadas } \\
\text { nesse termo }\end{array}$ \\
\hline Atividade catalítica & 350 & 47,74 \\
\hline Atividade estrutural & 356 & 48,56 \\
\hline Atividade de transporte & 228 & 31,10 \\
\hline Atividade antioxidante & 1 & 0,13 \\
\hline Adesão celular & 6 & 0,81 \\
\hline Regulação da apoptose & 5 & 0,68 \\
\hline Atividade protein tagging & 5 & 0,68 \\
\hline Citoesqueleto & 2 & 0,27 \\
\hline Ligação & 526 & 71,75 \\
\hline Atividade signal transducer & 34 & 4,63 \\
\hline Função molecular desconhecida & 63 & 8,59 \\
\hline Regulação da tradução & 2 & 0,27 \\
\hline Regulação enzimática & 33 & 4,50 \\
\hline Atividade chaperone & 31 & 4,22 \\
\hline Atividade motora & 6 & 0,81 \\
\hline Regulação da transcrição & 43 & 5,86 \\
\hline Obsoleto & 29 & 3,95 \\
\hline
\end{tabular}


Tabela 8. Resultados da anotação pelo Gene Ontology (GO) para as seqüências da biblioteca EB2

\begin{tabular}{|c|c|c|}
\hline \multicolumn{3}{|c|}{ Componente Celular - 522} \\
\hline Categoria & $\begin{array}{c}\mathrm{N}^{0} \text { de } \\
\text { seqüências }\end{array}$ & $\begin{array}{c}\text { \% das } 522 \text { seqüências classificadas } \\
\text { nesse termo }\end{array}$ \\
\hline Extracelular & 52 & 9,96 \\
\hline Célula & 500 & 95,78 \\
\hline Não localizado & 25 & 4,78 \\
\hline Obsoleto & 27 & 5,17 \\
\hline Componente celular desconhecido & 48 & 9,19 \\
\hline \multicolumn{3}{|c|}{ Processo Biológico - 540} \\
\hline Categoria & $\begin{array}{l}\mathrm{N}^{\circ} \mathrm{de} \\
\text { seqüências }\end{array}$ & $\begin{array}{c}\% \text { das } 540 \text { seqüências classificadas } \\
\text { nesse termo }\end{array}$ \\
\hline Desenvolvimento & 206 & 38,14 \\
\hline Processo celular & 322 & 59,62 \\
\hline Processo biológico desconhecido & 47 & 9,00 \\
\hline Processo fisiológico & 438 & 83,90 \\
\hline Comportamento & 12 & 2,29 \\
\hline Obsoleto & 74 & 14,17 \\
\hline \multicolumn{3}{|c|}{ Função Molecular - 518} \\
\hline Categoria & $\begin{array}{l}\mathrm{N}^{\mathrm{o}} \mathrm{de} \\
\text { seqüências }\end{array}$ & $\begin{array}{c}\text { \% das } 518 \text { seqüências classificadas } \\
\text { nesse termo }\end{array}$ \\
\hline Atividade catalítica & 271 & 53,31 \\
\hline Atividade estrutural & 218 & 42,08 \\
\hline Atividade de transporte & 108 & 20,84 \\
\hline Atividade antioxidante & 0 & 0 \\
\hline Adesão celular & 2 & 0,38 \\
\hline Regulação da apoptose & 5 & 0,96 \\
\hline Atividade protein tagging & 3 & 0,57 \\
\hline Citoesqueleto & 1 & 0,19 \\
\hline Ligação & 320 & 61,77 \\
\hline Atividade signal transducer & 15 & 2,89 \\
\hline Função molecular desconhecida & 43 & 8,30 \\
\hline Regulação da tradução & 0 & 0 \\
\hline Regulação enzimática & 0 & 0 \\
\hline Atividade chaperone & 10 & 1,93 \\
\hline Atividade motora & 6 & 1,15 \\
\hline Regulação da transcrição & 14 & 2,70 \\
\hline Obsoleto & 0 & 0 \\
\hline
\end{tabular}


Tabela 9. Resultados da anotação pelo Gene Ontology (GO) para as seqüências da biblioteca CB1

\begin{tabular}{|c|c|c|}
\hline \multicolumn{3}{|c|}{ Componente Celular - 640} \\
\hline Categoria & $\begin{array}{c}\mathrm{N}^{0} \mathrm{de} \\
\text { seqüências }\end{array}$ & $\begin{array}{c}\text { \% das } 640 \text { seqüências classificadas } \\
\text { nesse termo }\end{array}$ \\
\hline Extracelular & 37 & 5,8 \\
\hline Célula & 615 & 96,09 \\
\hline Não localizado & 45 & 7,03 \\
\hline Obsoleto & 21 & 3,28 \\
\hline Componente celular desconhecido & 55 & 8,59 \\
\hline \multicolumn{3}{|c|}{ Processo Biológico - 655} \\
\hline Categoria & $\begin{array}{l}N^{0} \text { de } \\
\text { seqüências }\end{array}$ & $\begin{array}{c}\% \text { das } 655 \text { seqüências classificadas } \\
\text { nesse termo }\end{array}$ \\
\hline Desenvolvimento & 303 & 49,25 \\
\hline Processo celular & 471 & 71,90 \\
\hline Processo biológico desconhecido & 68 & 10,38 \\
\hline Processo fisiológico & 542 & 82,74 \\
\hline Ciclo de vida viral & 0 & 0 \\
\hline Comportamento & 10 & 1,52 \\
\hline Obsoleto & 65 & 9,92 \\
\hline \multicolumn{3}{|c|}{ Função Molecular - 645} \\
\hline Categoria & $\begin{array}{c}\mathrm{N}^{0} \text { de } \\
\text { seqüências }\end{array}$ & $\begin{array}{c}\% \text { das } 645 \text { seqüências classificadas } \\
\text { nesse termo }\end{array}$ \\
\hline Atividade catalítica & 360 & 55,81 \\
\hline Atividade estrutural & 326 & 50,54 \\
\hline Atividade de transporte & 213 & 33,02 \\
\hline Atividade antioxidante & 2 & 0,31 \\
\hline Adesão celular & 0 & 0 \\
\hline Regulação da apoptose & 6 & 0,93 \\
\hline Atividade protein tagging & 4 & 0,62 \\
\hline Citoesqueleto & 3 & 0,46 \\
\hline Ligação & 417 & 64,65 \\
\hline Atividade signal transducer & 19 & 2,94 \\
\hline Função molecular desconhecida & 43 & 6,66 \\
\hline Regulação da tradução & 1 & 0,15 \\
\hline Regulação enzimática & 42 & 6,51 \\
\hline Atividade chaperone & 19 & 2,94 \\
\hline Atividade motora & 10 & 1,55 \\
\hline Regulação da transcrição & 0 & 0 \\
\hline Obsoleto & 22 & 3,41 \\
\hline
\end{tabular}

Com base nos resultados apresentados nas tabelas de anotação pelo GO pode-se verificar que a categoria desenvolvimento apresentou um número 
maior de seqüências classificadas. Isto ocorreu nas bibliotecas EB1 e CB1 construídas a partir da linhagem de corte (TT).

\subsection{Análise de polimorfismo}

O número de polimorfismos de base única chamado de SNPs (Single Nucleotide Polimorphisms) foi calculado para os contigs gerados na clusterização das bibliotecas EB1 e EB2 a fim de comparar as duas linhagens na fase embrionária. A freqüência de polimorfismos foi calculada como sendo $1,4 \times 10^{-3}$ o que representa aproximadamente 1 alteração a cada 1000 bases seqüenciadas. O critério utilizado para definir os SNPs foi a qualidade da base, sendo considerados os que apresentassem qualidade Phred maior ou igual a 40. Esse índice foi calculado dividindo-se o número de alterações encontradas pelo total de bases dos contigs analisados. Estudos de ESTs em frangos revelaram taxas diferentes da encontrada para este estudo. Smith et al. (2001) encontraram uma alteração a cada 470 bases. Os dados obtidos na análise de SNPs podem fornecer dados importantes para a construção de mapas genéticos e estudos de genes candidatos. Na Tabela 10 foram listados alguns genes para os quais foram detectados polimorfismos. Estes polimorfismos foram encontrados em contigs formados pelo alinhamento de reads das duas linhagens. 
Tabela 10. Polimorfismos identificados na análise conjunta das bibliotecas da fase embrionária (EB1 e EB2)

\begin{tabular}{|c|c|c|c|c|c|c|}
\hline Contig & $\begin{array}{l}\mathrm{N}^{\circ} \text { de } \\
\text { reads }\end{array}$ & $\begin{array}{l}\text { Reads por } \\
\text { Linhagem }\end{array}$ & Identificação & Posição * & Consenso & Base \\
\hline GGEZEB2015B04 & 3 & $2 \mathrm{TT} / 1 \mathrm{CC}$ & $\begin{array}{l}\text { Myosin alkali } \\
\text { light chain } 6 \text {, } \\
\text { smooth muscle } \\
\text { form }\end{array}$ & 395 (q:43) & G & $\mathrm{A}(\mathrm{TT})$ \\
\hline GGEZEB1016A09 & 4 & 3TT/1CC & Beta actin & 471 (q:40) & C & $\mathrm{T}(\mathrm{CC})$ \\
\hline GGEZEB2001H07 & 5 & $3 \mathrm{TT} / 2 \mathrm{CC}$ & $\begin{array}{c}\text { Myosin alkali } \\
\text { ligth chain } 1, \\
\text { fast skeletal } \\
\text { muscle }\end{array}$ & $\begin{array}{l}222(q: 52) \\
236(q: 41) \\
236(q: 41)\end{array}$ & $\begin{array}{l}\mathrm{C} \\
\mathrm{C} \\
\mathrm{C}\end{array}$ & $\begin{array}{l}\mathrm{G}(\mathrm{CC}) \\
\mathrm{T}(\mathrm{TT}) \\
\mathrm{T}(\mathrm{TT})\end{array}$ \\
\hline GGEZEB2018D10 & 5 & $3 \mathrm{TT} / 2 \mathrm{CC}$ & $\begin{array}{l}\text { Troponin } \mathrm{T} \\
\text { cardiac muscle } \\
\quad \text { isoform }\end{array}$ & $\begin{array}{l}132(q: 43) \\
132(q: 50)\end{array}$ & $\begin{array}{l}\mathrm{G} \\
\mathrm{G} \\
\mathrm{C}\end{array}$ & $\begin{array}{l}\mathrm{A}(\mathrm{TT}) \\
\mathrm{A}(\mathrm{TT}) \\
\mathrm{T}(\mathrm{TT})\end{array}$ \\
\hline GGEZEB1026A03 & 5 & 4TT/1CC & $\begin{array}{l}\text { Troponin I, fast } \\
\text { skeletal muscle }\end{array}$ & $193(q: 52)$ & $\mathrm{T}$ & $\mathrm{C}(\mathrm{TT})$ \\
\hline GGEZEB2001H04 & 4 & 3TT/1CC & $\begin{array}{l}\text { Troponin T, fast } \\
\text { skeletal muscle }\end{array}$ & $\begin{array}{l}263(\mathrm{q}: 44) \\
269 \text { (q:42) } \\
315(\mathrm{q}: 52) \\
371(\mathrm{q}: 40) \\
371 \text { (q:44) }\end{array}$ & $\begin{array}{l}\text { T } \\
\text { G } \\
A \\
A \\
A\end{array}$ & $\begin{array}{l}C(T T) \\
A(T T) \\
G(T T) \\
G(T T) \\
G(C C)\end{array}$ \\
\hline GGEZEB2004F04 & 12 & $8 \mathrm{TT} / 4 \mathrm{CC}$ & $\begin{array}{l}\text { Myosin alkali } \\
\text { light chain } 1 \text {, } \\
\text { fast skeletal } \\
\text { muscle }\end{array}$ & $656(q: 52)$ & G & $\mathrm{A}(\mathrm{TT})$ \\
\hline GGEZEB2001F10 & 22 & 14TT/8CC & $\begin{array}{c}\text { Troponin C, } \\
\text { skeletal muscle }\end{array}$ & $158(q: 56)$ & $\mathrm{C}$ & $\mathrm{T}(\mathrm{CC})$ \\
\hline GGEZEB1037A12 & 21 & $18 \mathrm{TT} / 3 \mathrm{CC}$ & $\begin{array}{l}\text { Myosin light } \\
\text { chain type } 2\end{array}$ & $\begin{array}{l}221 \text { (q:57) } \\
221 \text { (q:55) } \\
221 \text { (q:55) } \\
221(q: 42)\end{array}$ & $\begin{array}{l}\mathrm{G} \\
\mathrm{G} \\
\mathrm{G} \\
\mathrm{C}\end{array}$ & $\begin{array}{l}\text { A (TT) } \\
\text { A (TT) } \\
\text { A (TT) } \\
\text { T (TT) }\end{array}$ \\
\hline GGEZEB2004C05 & 57 & $45 \mathrm{TT} / 12 \mathrm{CC}$ & $\begin{array}{l}\text { Alpha actin } \\
\text { precursor }\end{array}$ & $621(q: 44)$ & G & $\mathrm{T}(\mathrm{TT})$ \\
\hline
\end{tabular}

* Posição do polimorfismo na seqüência consenso; q: qualidade da base 


\subsection{Análise das ESTs biblioteca-específicas}

A partir da clusterização conjunta das três bibliotecas construídas neste estudo (EB1, CB1 e EB2) foi possível identificar os contigs e singletons formados por ESTs biblioteca-específicas, ou seja, ESTs expressas em uma determinada idade ou linhagem. Vale ressaltar que esses resultados se aplicam apenas para o conjunto de ESTs identificadas neste estudo, e que poderiam portanto, sofrer alterações se um número maior de ESTs fosse seqüenciado para cada uma das bibliotecas.

A análise conjunta resultou em 716 contigs. Destes, 88 foram formados por reads da biblioteca EB1, o que representa $12,3 \%$ do total de contigs. Para CB1, 140 (19,6\%) contigs foram formados com reads biblioteca-específicos; e $41(5,73 \%)$ para EB2.

Foi observado que alguns dos contigs biblioteca-específicos identificados representavam genes envolvidos no processo de contração muscular. Entre os contigs biblioteca-específicos de EB2 (fase embrionária, linhagem CC) foram encontrados, por exemplo, troponina $C$ de músculo esquelético, miosina de cadeia pesada e troponina T cardíaca. Uma proteína conhecida como Caveolin também foi identificada como biblioteca-específica para EB2. Essa proteína é encontrada predominantemente em músculo e foi associada ao processo de migração celular (Minetti et al., 1998). Além desses, também foi encontrado um membro da família TGF $\beta$, o TGF $\beta$ 1-BP-1, descrito como potente inibidor de diferenciação muscular. Um outro contig identificado com associação ao programa miogênico específico dessa biblioteca de estádio embrionário representou uma proteína relacionada a Frizzled, um receptor de Wnt, efetor positivo da miogênese (Esteve et al., 2000).

Outro membro da família TGF- $\beta$, o TGF- $\beta-4$ foi identificado como biblioteca-específico para EB1 (fase embrionária da linhagem TT) e também está associado à regulação do processo de diferenciação muscular. Em adição, um contig representando o gene que codifica a proteína LIM, descrita como um 
regulador positivo de miogênese, também foi identificado nesta biblioteca. Laminina gama 1 também foi encontrado como contig biblioteca-específico para EB1 e foi descrito como mediador dos processos de agrupamento, migração e organização das células nos tecidos durante a fase embrionária por interação com outros componentes da matriz extracelular (Halfter et al., 2001). Em relação a genes envolvidos no processo de contração muscular foi identificado um contig que representa o gene da miosina regulatória de cadeia leve $2 \mathrm{~A}$. As miosinas são proteínas predominantes no tecido muscular (cerca de um terço de todas as proteínas musculares), envolvidas no processo de contração muscular (Picard et al., 2002). Neste estudo, foram encontrados contigs representando diferentes isoformas de miosinas entre as bibliotecas. Mesmo entre as bibliotecas da fase embrionária ocorreram contigs representado isoformas diferentes. Resultados semelhantes foram encontrados em estudo de ESTs da musculatura peitoral em suínos (Davoli et al., 1999).

Dentre os contigs biblioteca-específicos de CB1 (fase pós- eclosão, linhagem TT) foram identificados miosina de cadeia pesada, troponina $T$ de músculo esquelético de contração rápida e troponina $T$ de músculo esquelético, isoforma 2, além da tropomiosina de cadeia $\alpha$. Em adição, duas isoformas de miosinas também foram encontradas somente nesta biblioteca, são elas: miosina XVIIIb e miosina de cadeia pesada isoforma neonatal. De acordo com Tidyman et al., 1997 a isoforma de miosina Cneo (neonatal) é expressa, inicialmente em baixos níveis, antes da eclosão e aumenta substancialmente após a eclosão.

Outro gene importante representado por um contig desta biblioteca é o receptor de rianodina tipo 1 (RyR1), que é fundamental no controle do fluxo de cálcio nas fibras musculares (Ottini et al., 1996). Em suínos foi comprovada uma associação direta entre a ocorrência de carne PSE (pálida, flácida e exsudativa) com uma mutação no gene que codifica a proteína receptora de rianodina (Fujii et al., 1991). 
Esses dados diferem do que foi encontrado para as bibliotecas da fase embrionária, mostrando que existe a ocorrência de diferentes isoformas destas proteínas dependendo da fase de desenvolvimento do animal.

\subsection{Análise de expressão gênica}

A técnica de PCR em tempo real foi utilizada para medir a expressão dos fatores miogênicos (MyoD, miogenina e MRF4), Pax-3 e miostatina nas linhagens de corte (TT) e postura (CC). As idades utilizadas foram: 9 e 17 dias de incubação (fase embrionária) e 1 e 21 dias de idade (fase pós-eclosão).

\subsubsection{Extração de RNA total}

Para a extração de RNA total foram utilizadas amostras de tecido (músculo pectoralis) de 5 animais de cada idade (9 e 17 dias de incubação; 1 e 21 dias de idade) das duas linhagens (TT - corte e CC - postura). A eletroforese em gel de agarose 1\% permitiu identificar a integridade das amostras de RNA total (Figuras 23 e 24). A integridade do material é avaliada pela presença das bandas estruturais de RNA ribossômico (28S, 18S e 5,8 S). Após a verificação da qualidade do RNA total e quantificação em espectrofômetro, procedeu-se a síntese de cDNA empregado nas análises de expressão gênica. 


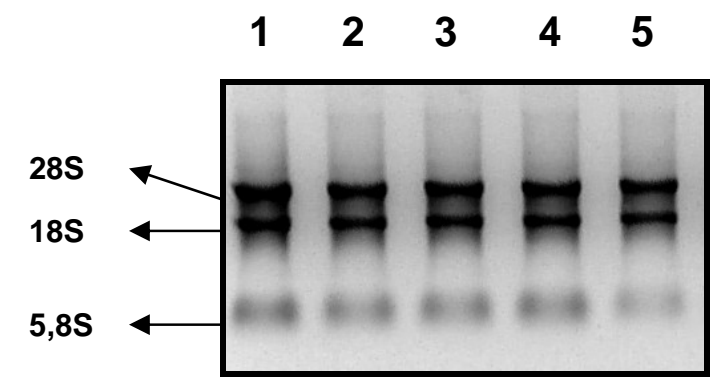

Figura 23 - Fotografia de gel de agarose 1\% para verificação da qualidade do RNA total. As canaletas de 1 a 5 correspondem ao RNA extraído de amostras da musculatura peitoral de embriões de 17 dias (Estádio E43) da linhagem CC

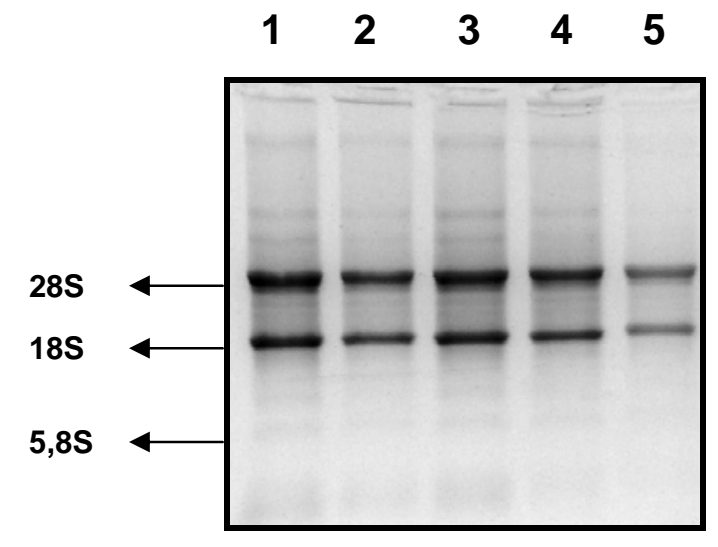

Figura 24 - Fotografia de gel de agarose 1\% para verificação da qualidade do RNA total. As canaletas de 1 a 5 correspondem ao RNA extraído de amostras da musculatura peitoral de embriões de 17 dias (Estádio E43) da linhagem TT

\subsubsection{PCR em tempo real}

O cDNA sintetizado a partir do RNA total extraído das amostras de tecido peitoral foi empregado nas reações de PCR em tempo real com o objetivo de 
estabelecer as condições de amplificação para cada um dos genes estudados. Dessa forma foram estabelecidas as condições para amplificação em tempo real dos genes: $\beta$-actina, MyoD, MRF4, miogenina Pax-3 e miostatina (Anexos $A-E)$.

\subsubsection{Análise de expressão dos fatores miogênicos: MyoD, MRF4 e miogenina; Pax-3 e miostatina}

Apesar dos avanços nos estudos dos genes envolvidos nos processos de regulação da formação da musculatura esquelética durante os primeiros estádios de desenvolvimento, existem poucos trabalhos descrevendo a ação destes genes tanto na fase final do desenvolvimento embrionário como na fase pós-eclosão. Neste sentido, a técnica de PCR em tempo real foi utilizada com o intuito de investigar a expressão dos fatores miogênicos (MyoD, miogenina e MRF4), Pax-3 e miostatina. Além destes, também foi analisada a expressão de $\beta$-actina, um gene constitutivo utilizado como controle.

Para essas análises foram utilizados 5 animais de cada idade (9 e 17 dias de incubação; 1 e 21 dias de idade) das duas linhagens (TT e CC). As amostras foram analisadas em duplicata. Como ilustração, a reação e curva de melting para o fator miogênico miogenina, são apresentados nas Figuras 25 e 26. Os resultados de expressão gênica da fase embrionária (9 e 17 dias de incubação) e pós-eclosão (1 e 21 dias de idade) estão representados nas Tabelas 11, 12 e 13. 


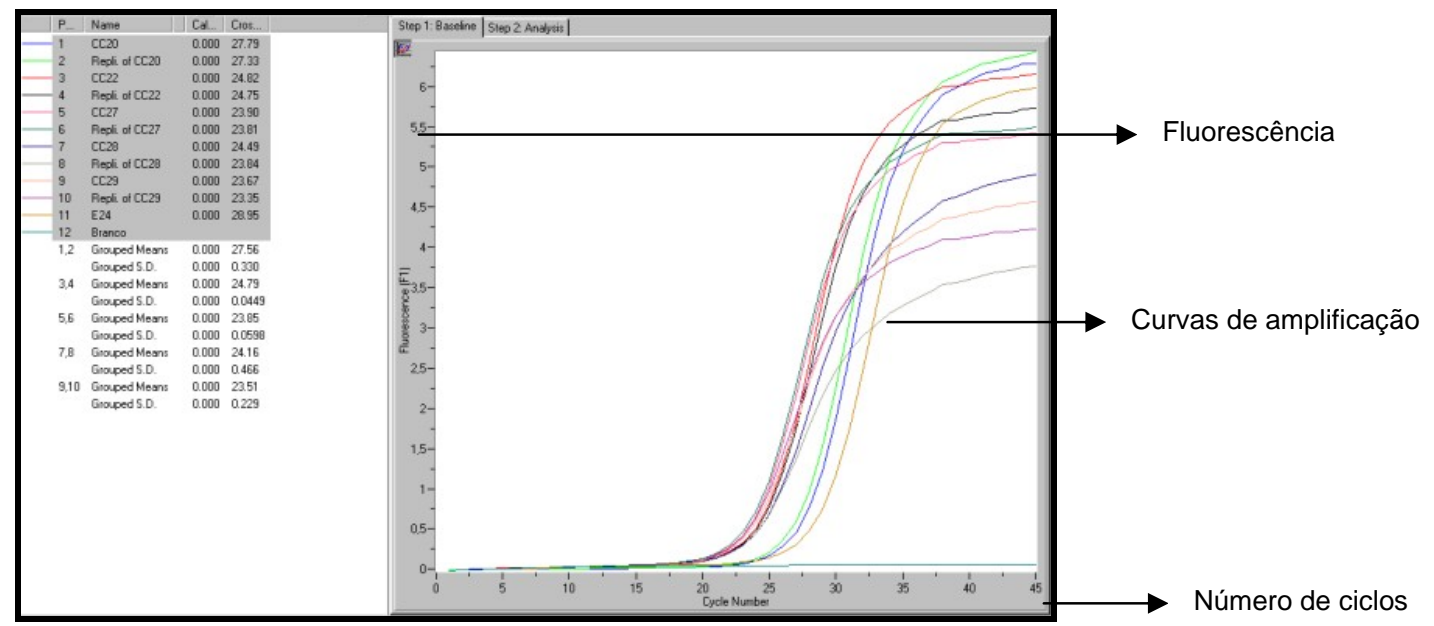

Figura 25 - Resultado da amplificação do fator miogênico miogenina em embriões de 9 dias de incubação.

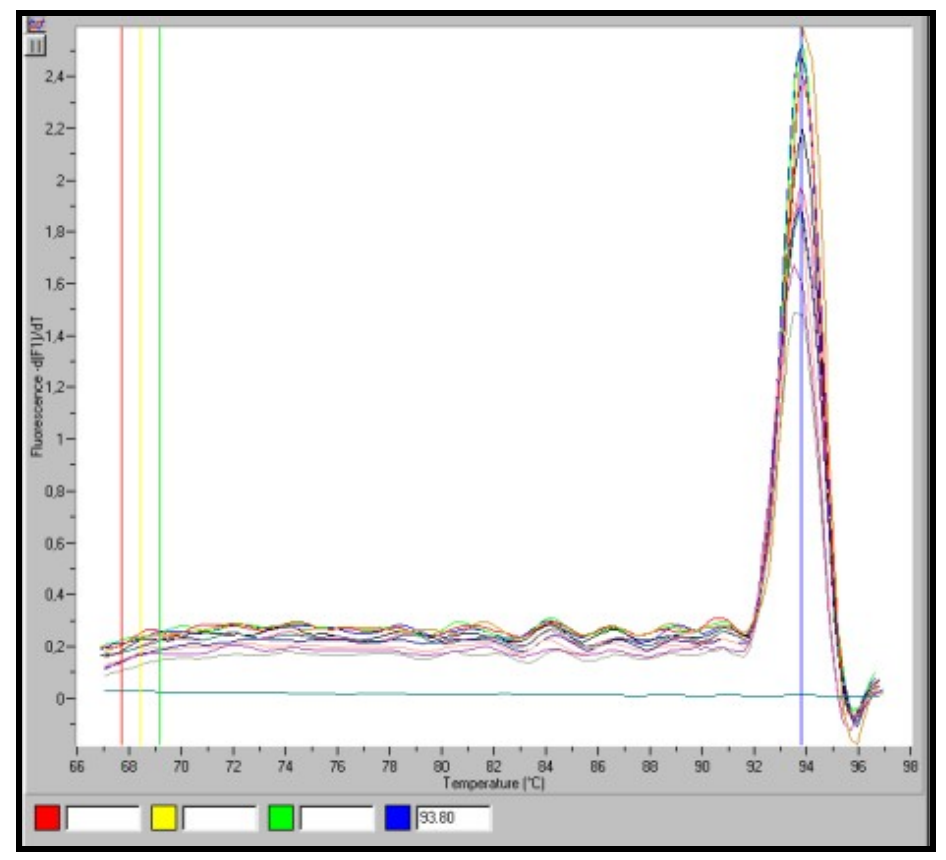

Figura 26 - Curvas de melting das amostras amplificadas para miogenina em embriões de 9 dias de incubação. 
$\mathrm{Na}$ Figura 25 pode ser observado que os produtos amplificados para o gene miogenina começaram a ser detectados em torno do ciclo 20. Além disso, pela análise da curva de melting (Figura 26) pode-se verificar que os produtos amplificados desnaturaram na mesma temperatura $\left(93,8{ }^{\circ} \mathrm{C}\right)$ e que não ocorreram amplificações inespecíficas e nem a formação de dímeros de primers.

Tabela 11. Médias e desvios-padrão da expressão de $\beta$-actina nas fases: embrionária e pós-eclosão descritas em unidades Ct

\begin{tabular}{lrcc}
\hline & & \multicolumn{2}{c}{$\beta$-actina } \\
Idade & $\mathrm{n}$ & $\mathrm{TT}$ & $\mathrm{CC}$ \\
\hline E9 & 10 & $22,96^{\mathrm{Ca}} \pm 3,4$ & $16,90^{\mathrm{Ab}} \pm 0,4$ \\
E17 & 10 & $18,44^{\mathrm{Aa}} \pm 1,3$ & $15,64^{\mathrm{Ab}} \pm 1,3$ \\
D1 & 10 & $23,42^{\mathrm{Ca}} \pm 2,4$ & $21,18^{\mathrm{Bb}} \pm 0,9$ \\
D21 & 10 & $20,47^{\mathrm{Ba}} \pm 3,6$ & $20,11^{\mathrm{Ba}} \pm 2,7$
\end{tabular}

E9: 9dias de incubação; E17: 17dias de incubação; D1: 1 dia de idade; D21: 21 dias de idade; TT: linhagem de corte; CC: linhagem de postura. Médias seguidas de mesma letra maiúscula na coluna e minúscula na linha não diferem entre si pelo teste $T(p<0,10) . n$ : $n^{\circ}$ de observações

A expressão de $\beta$-actina foi significativamente maior $(p<0,10)$ na fase embrionária, bem como com 1 dia de idade, nos animais da linhagem CC. Aos 21 dias de idade a expressão foi igual nas duas linhagens (Tabela 11). 
Tabela 12. Médias e desvios-padrão da expressão dos fatores miogênicos MyoD, miogenina e MRF4 nas fases: embrionária e pós-eclosão descritas em unidades $\Delta \mathrm{Ct}$

\begin{tabular}{lccccccc}
\hline & & \multicolumn{2}{c}{ MyoD } & \multicolumn{2}{c}{ Miogenina } & \multicolumn{2}{c}{ MRF4 } \\
Idade & $\mathrm{n}$ & $\mathrm{TT}$ & $\mathrm{CC}$ & $\mathrm{TT}$ & $\mathrm{CC}$ & $\mathrm{TT}$ & $\mathrm{CC}$ \\
\hline $\mathrm{E} 9$ & 10 & $9,20^{\mathrm{Ca}} \pm 2,3$ & $12,14^{\mathrm{Ca}} \pm 2,3$ & $-0,28^{\mathrm{Aa}} \pm 1,2$ & $7,17^{\mathrm{Bb}} \pm 1,2$ & $6,83^{\mathrm{Aa}} \pm 2,1$ & $18,47^{\mathrm{Bb}} \pm 2,1$ \\
$\mathrm{E} 17$ & 10 & $4,59^{\mathrm{Ba}} \pm 1,0$ & $8,19^{\mathrm{Bb}} \pm 1,0$ & $4,60^{\mathrm{Ba}} \pm 0,5$ & $6,50^{\mathrm{ABa}} \pm 0,5$ & $12,48^{\mathrm{Ba}} \pm 0,9$ & $19,21^{\mathrm{Bb}} \pm 0,9$ \\
$\mathrm{D} 1$ & 10 & $-2,23^{\mathrm{Aa}} \pm 0,6$ & $-0,04^{\mathrm{Aa}} \pm 0,6$ & $3,61^{\mathrm{Ba}} \pm 0,7$ & $4,40^{\mathrm{Aa}} \pm 0,7$ & $8,01^{\mathrm{Aa}} \pm 0,6$ & $14,26^{\mathrm{Ab}} \pm 0,6$ \\
$\mathrm{D} 21$ & 10 & $2,55^{\mathrm{Ba}} \pm 1,7$ & $1,41^{\mathrm{Aa}} \pm 1,7$ & $5,62^{\mathrm{Ba}} \pm 1,3$ & $6,34^{\mathrm{ABa}} \pm 1,3$ & $11,49^{\mathrm{Ba}} \pm 1,1$ & $12,81^{\mathrm{Aa}} \pm 1,1$
\end{tabular}

E9: 9dias de incubação; E17: 17dias de incubação; D1: 1 dia de idade; D21: 21 dias de idade; TT: linhagem de corte; CC: linhagem de postura. Médias seguidas de mesma letra maiúscula na coluna e minúscula na linha não diferem entre si pelo teste $T(p<0,10) . n$ : $n^{0}$ de observações

Tabela 13. Médias e desvios-padrão da expressão dos genes Pax-3 e miostatina nas fases: embrionária e pós-eclosão descritas em unidades $\Delta \mathrm{Ct}$

\begin{tabular}{lrcccc}
\hline & & \multicolumn{2}{c}{ Pax-3 } & \multicolumn{2}{c}{ Miostatina } \\
Idade & $\mathrm{n}$ & $\mathrm{TT}$ & $\mathrm{CC}$ & $\mathrm{TT}$ & $\mathrm{CC}$ \\
\hline $\mathrm{E} 9$ & 10 & $12,08^{\mathrm{Aa}} \pm 1,3$ & $24,07^{\mathrm{ABb}} \pm 1,3$ & $2,77^{\mathrm{Aa}} \pm 1,2$ & $19,64^{\mathrm{Cb}} \pm 1,2$ \\
$\mathrm{E} 17$ & 10 & $17,81^{\mathrm{Ba}} \pm 1,1$ & $26,72^{\mathrm{Bb}} \pm 1,1$ & $10,72^{\mathrm{Ba}} \pm 0,6$ & $11,98^{\mathrm{Ba}} \pm 1,3$ \\
D1 & 10 & $21,78^{\mathrm{Ca}} \pm 1,9$ & $20,59^{\mathrm{Aa}} \pm 1,9$ & $8,32^{\mathrm{Ba}} \pm 1,0$ & $10,32^{\mathrm{Ba}} \pm 1,0$ \\
D21 & 10 & $25,59^{\mathrm{Da}} \pm 1,6$ & $27,91^{\mathrm{Ba}} \pm 1,6$ & $8,94^{\mathrm{Ba}} \pm 1,5$ & $6,79^{\mathrm{Aa}} \pm 1,5$
\end{tabular}

E9: 9dias de incubação; E17: 17dias de incubação; D1: 1 dia de idade; D21: 21 dias de idade; TT: linhagem de corte; CC: linhagem de postura. Médias seguidas de mesma letra maiúscula na coluna e minúscula na linha não diferem entre si pelo teste $T(p<0,10) . n$ : $n^{0}$ de observações

Com base nos resultados apresentados na Tabela 12 pode-se observar que a expressão do fator miogênico MyoD foi maior na linhagem de corte (TT) em relação à de postura $(\mathrm{CC})$ durante a fase embrionária, bem como na fase pós-eclosão com 1 dia de idade. Por outro lado, aos 21 dias, a expressão de MyoD decresce na linhagem de corte e torna-se maior na linhagem de postura. Em relação aos fatores miogênicos miogenina e MRF4 pode-se verificar que a expressão dos mesmos foi maior na linhagem de corte em todas as idades 
analisadas. Entretanto, a diferença na expressão de MRF4 entre as duas linhagens, principalmente na fase embrionária, foi maior em relação às diferenças observadas para os outros dois fatores (miogenina e MyoD). Tomados juntos, esses dados sugerem uma maior diferenciação do tecido muscular na linhagem de corte em relação à de postura.

Em estudos anteriores conduzidos por Álvares (2001), utilizando embriões inteiros das mesmas linhagens (TT, corte e CC, postura) a expressão de MyoD e miogenina foi maior na linhagem de corte no estádio 26 de desenvolvimento.

Análises de expressão dos fatores miogênicos na musculatura peitoral de embriões e adultos indicaram que RNAs mensageiros de MyoD e MRF4 estão presentes em altos níveis em todos os estádios de desenvolvimento embrionário, bem como em adultos. Além disso, os níveis de expressão do fator miogênico miogenina aumentam entre os estádios E8 e E10, decrescem até o estádio E17 e está presente em baixos níveis em adultos (Cheng et al., 1992; Saitoh et al., 1993). Em adição, experimentos conduzidos em culturas de mioblastos fetais (isolados do músculo peitoral de embriões E11) e adultos (isolados do músculo peitoral de aves de 3 semanas de idade) foi analisada a expressão dos fatores miogênicos MyoD e miogenina. Os autores verificaram a expressão dos fatores MyoD e miogenina em ambas culturas. (YablonkaReuveni \& Paterson, 2001).

De acordo com os dados apresentados na Tabela 13, a expressão de miostatina foi maior no estádio E9 do desenvolvimento embrionário, decrescendo aos 17 dias de incubação (E17) e aumentando ligeiramente na fase pós-eclosão. A expressão foi maior na linhagem de corte desde a fase embrionária até 1 dia de idade. Aos 21 dias de idade a expressão de miostatina tornou-se maior na linhagem de postura. Uma vez que a miostatina é um potente inibidor de diferenciação muscular, esperava-se que sua expressão fosse maior na linhagem de postura em todos os estádios analisados, porém, isto ocorreu somente aos 21 dias de idade. Talvez isso possa ser explicado pelo fato de existirem genes regulando a expressão da miostatina na fase 
embrionária, como é o caso da folistatina (Kocamis et al., 1999). Por outro lado, Álvares (2001) obteve maiores concentrações de transcritos para miostatina na linhagem de postura em todas as fases embrionárias estudadas.

A expressão de Pax-3 foi maior na linhagem TT durante a fase embrionária, porém, com 1 dia de idade (fase pós-eclosão) a expressão foi ligeiramente maior na linhagem de postura. Com o decorrer do desenvolvimento, aos 21 dias de idade, a expressão de Pax-3 voltou a ser maior na linhagem de corte (Tabela 13). Além de ser descrito como um importante regulador da miogênese (nas fases iniciais de formação do músculo), Pax-3 também desempenha papel crucial na formação do músculo esquelético adulto (Bukingham, 2001). 


\section{CONCLUSÕES}

Em tais condições conclui-se que:

- As seqüências EST identificadas neste trabalho possibilitaram a construção de um banco com 6247 ESTs da musculatura peitoral de duas linhagens de frango em diferentes fases de desenvolvimento fornecendo recursos para futuras análises nas áreas celular e molecular de desenvolvimento;

- Os dados gerados neste estudo poderão ser empregados em análises comparativas entre espécies; 
ANEXOS 


\section{Anexo A}

\section{Otimização da reação de PCR para o gene MyoD}

Para o fator miogênico MyoD foram feitos testes para obter-se uma condição otimizada de amplificação. Como resultado a temperatura de anelamento ficou em $57^{\circ} \mathrm{C}$ (condição otimizada em termociclador convencional) e concentração de $\mathrm{MgCl}_{2}$ de $3 \mathrm{mM}$. Foram ajustados os parâmetros de amplificação em tempo real (tempo de desnaturação, anelamento, extensão, bem como o ajuste da curva de melting). Os resultados da otimização podem ser visualizados nas Figuras 1, 2 e 3.

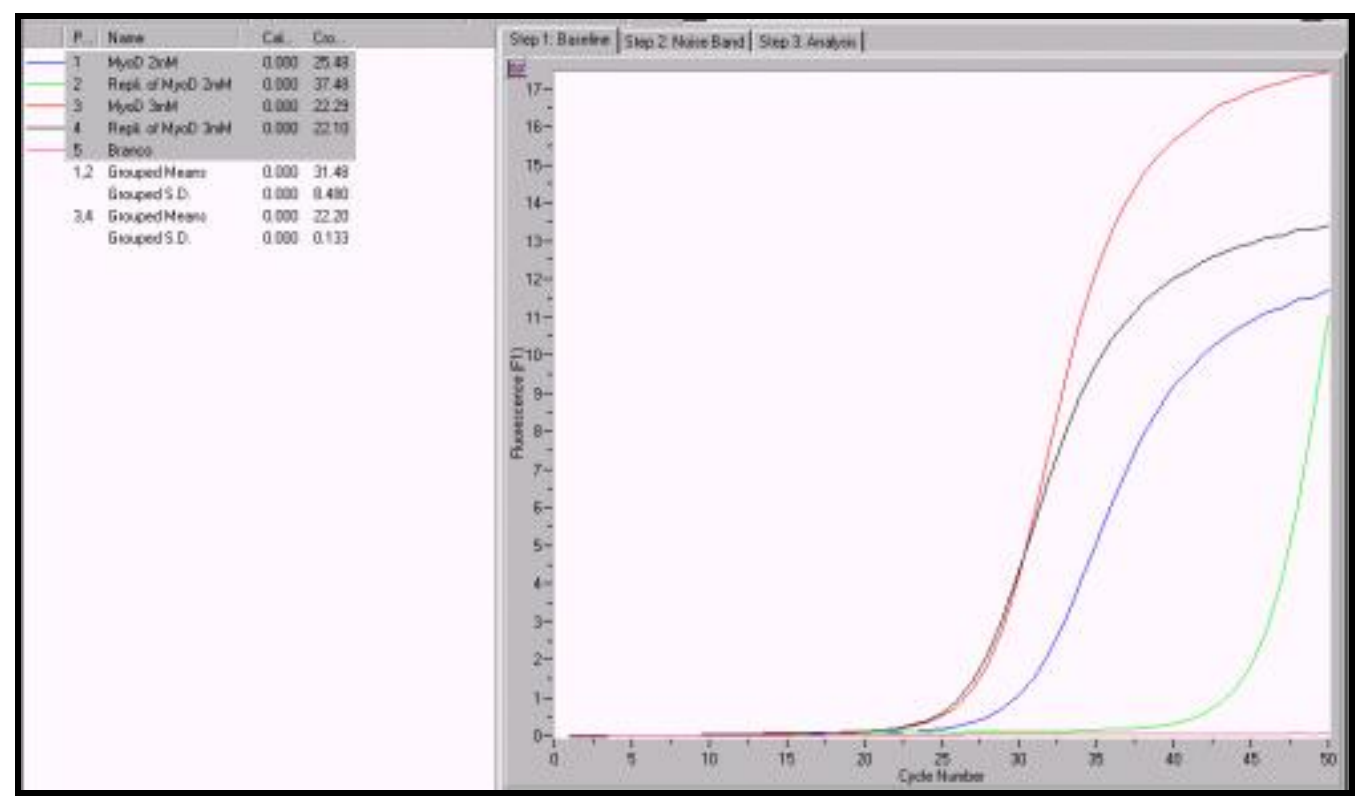

Figura 1 - Resultado da amplificação por PCR em tempo real do fator miogênico MyoD com duas concentrações de $\mathrm{MgCl}_{2}$

Pode-se verificar que houve amplificação para as reações feitas com 2 e $3 \mathrm{mM}$ de $\mathrm{MgCl}_{2}$, porém, os produtos amplificados com $3 \mathrm{mM}$ de $\mathrm{MgCl}_{2}$ foram 
detectados mais cedo (ao redor do ciclo 20). Além disso, houve menor variação entre as duas amostras em relação à concentração de $2 \mathrm{mM}$ de $\mathrm{MgCl}_{2}$.

Quanto ao resultado da curva de melting (Figura 2) pode-se verificar que os produtos amplificados na reação de PCR desnaturaram na mesma temperatura $\left(90,6^{\circ} \mathrm{C}\right)$ e que não ocorreram amplificações inespecíficas em nem a formação de dímeros de primers.

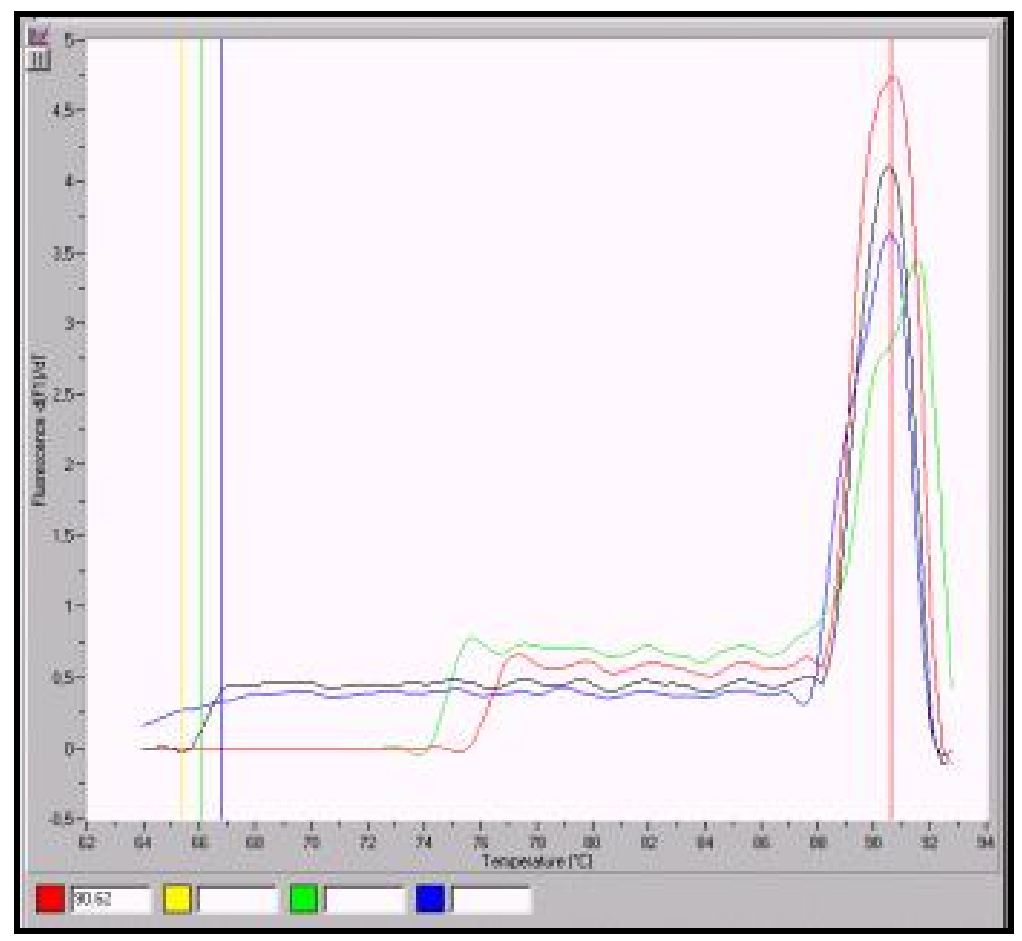

Figura 2 - Curvas de melting das amostras amplificadas para o fator miogênico MyoD com duas concentrações de $\mathrm{MgCl}_{2}$

Para confirmação desses resultados as amostras foram submetidas à eletroforese em gel de agarose 1\% (Figura 3), onde se pode verificar a melhor condição de otimização. Trata-se da reação feita com $3 \mathrm{mM}$ de $\mathrm{MgCl}_{2}$, uma vez que foi confirmada a amplificação de produtos específicos para o gene MyoD e a ausência de amplificação inespecífica. 


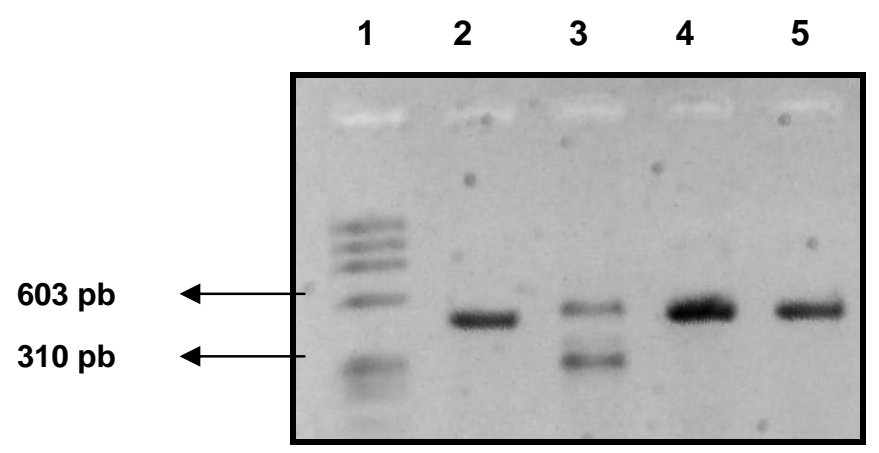

Figura 3 - Fotografia de gel de agarose 1\% para visualização da amostras amplificadas em reação de PCR em tempo real para o fator miogênico MyoD. A canaleta 1 - corresponde ao marcador de peso molecular $\phi$ X 174 (Invitrogen); 2 e 3 - concentração de $\mathrm{MgCl}_{2}$ de 2 $\mathrm{mM}$; 4 e 5 - concentração de $\mathrm{MgCl}_{2}$ de $3 \mathrm{mM}$ 


\section{Anexo B}

\section{Otimização da reação de PCR para o gene MRF4}

Para o fator miogênico MRF4, assim como para os demais genes, iniciou-se a otimização com as condições estabelecidas por Álvares (2001), porém não foi possível a otimização das condições de amplificação. Por isso optou-se por testar outros pares de primers disponíveis no laboratório e depois de alguns testes chegou-se em uma condição otimizada. A temperatura de anelamento ficou em $55^{\circ} \mathrm{C}$ e concentração de $\mathrm{MgCl}_{2}$ de $2 \mathrm{mM}$. O resultado da otimização pode ser observado nas Figuras 1, 2 e 3.

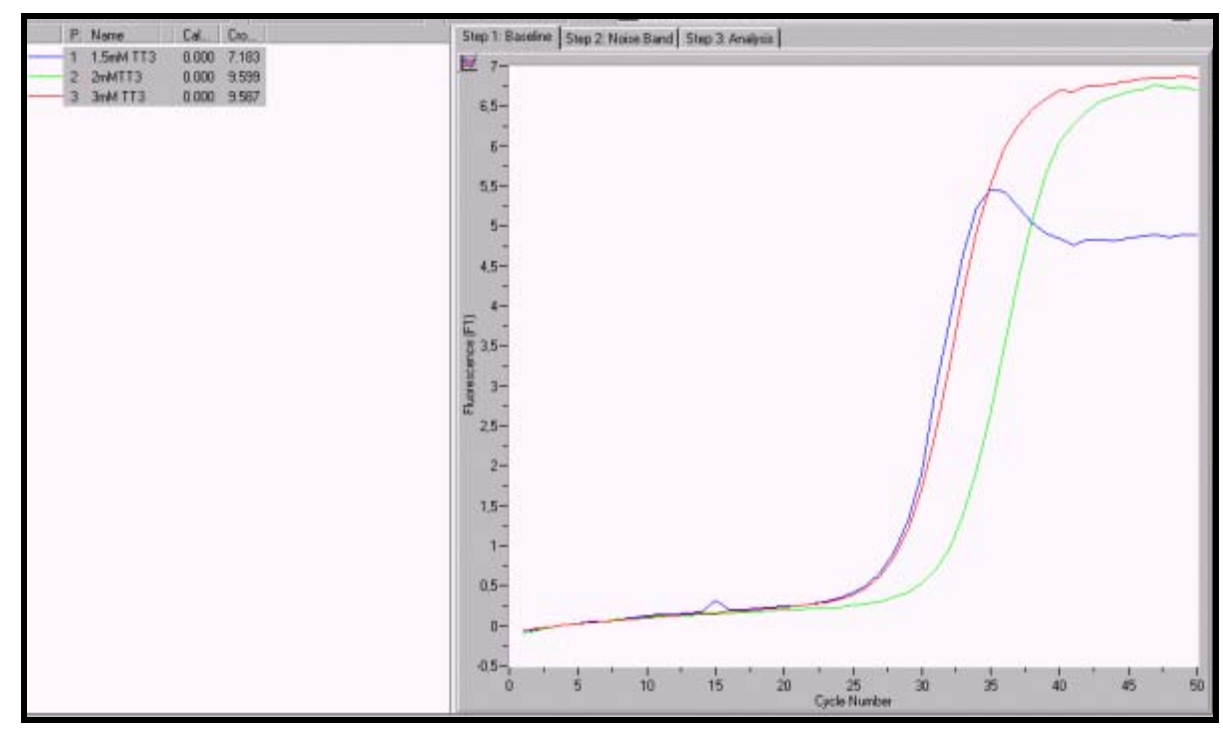

Figura 1 - Resultado da amplificação por PCR em tempo real do fator miogênico MRF4 com três concentrações de $\mathrm{MgCl}_{2}$ 


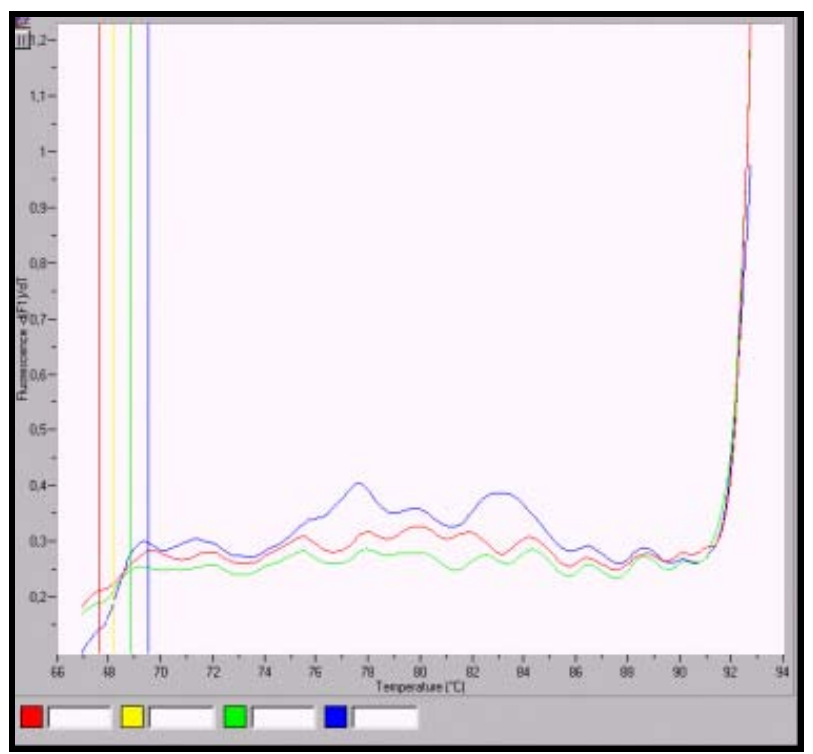

Figura 2 - Curva de melting para o fator miogênico MRF4

Pode-se observar que a temperatura de melting para o fator miogênico MRF4 foi em torno de $93^{\circ} \mathrm{C}$. Para a confirmação dos resultados as amostras foram submetidas à eletroforese em gel de agarose 1\% (Figura 3).

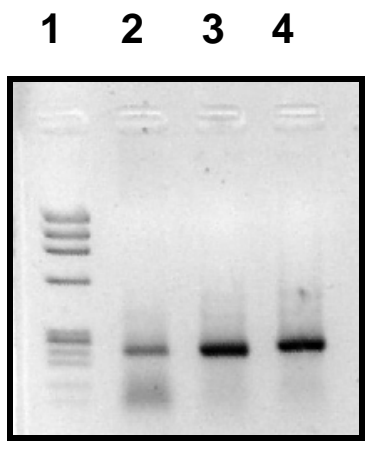

Figura 3 - Fotografia de gel de agarose 1\% para visualização da amostras amplificadas em reação de PCR em tempo real para o fator miogênico MRF4. A canaleta 1 - corresponde ao marcador de peso molecular $\phi$ X 174 (Invitrogen); 2- concentração de $\mathrm{MgCl}_{2}$ de 1,5 mM; 3 - concentração de $\mathrm{MgCl}_{2}$ de $2 \mathrm{mM}$ e 4 - concentração de $\mathrm{MgCl}_{2}$ de $3 \mathrm{mM}$ 


\section{Anexo C}

\section{Otimização da reação de PCR para o gene miogenina}

Para o fator miogênico miogenina, da mesma forma que MRF4, foi necessária a troca dos pares de primers a fim de se estabelecer as melhores condições de amplificação para esse fator. Após vários testes chegou-se a uma temperatura de anelamento de $55^{\circ} \mathrm{C}$ e concentração de $\mathrm{MgCl}_{2}$ de $3 \mathrm{mM}$. Foram ajustados os parâmetros de amplificação em tempo real (tempo de desnaturação, anelamento e extensão, bem como ajuste da curva de melting). Nas Figuras 1 e 2 podem ser visualizados os resultados da otimização das condições de amplificação por PCR em tempo real para este fator.

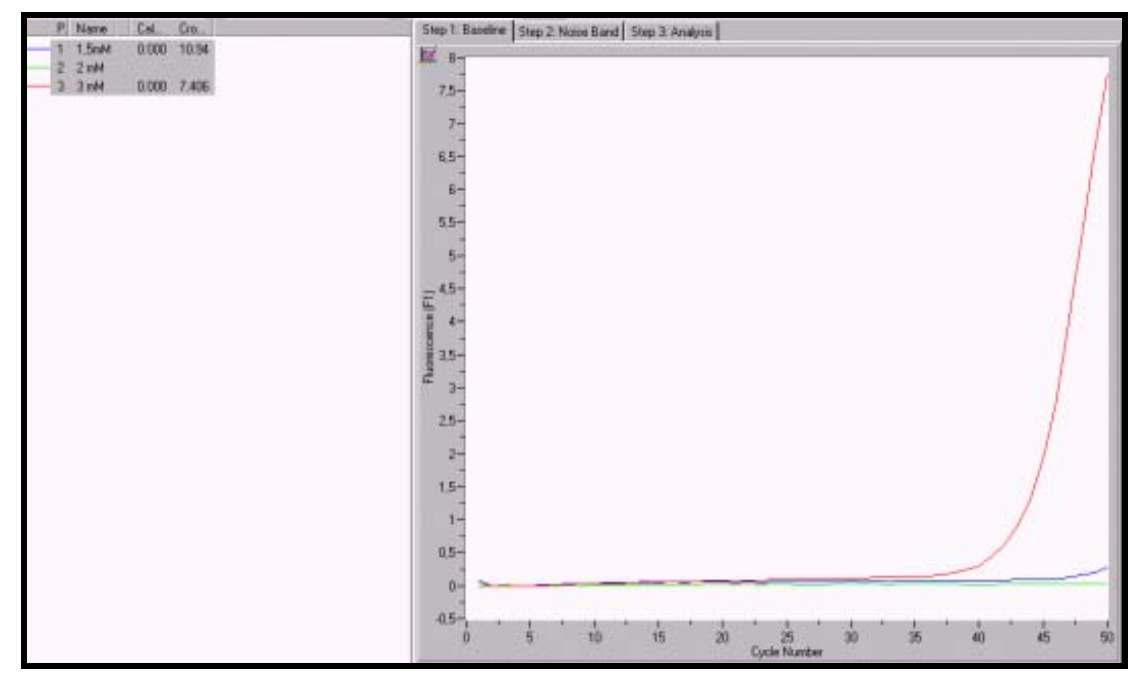

Figura 1 - Resultado da amplificação por PCR em tempo real do fator miogênico miogenina com três concentrações de $\mathrm{MgCl}_{2}$

Pode-se observar que a reação feita com $3 \mathrm{mM}$ de $\mathrm{MgCl} 2$ foi a que apresentou melhor resultado, sendo detectado produto amplificado em torno do 
ciclo 30. A temperatura de melting para o fator miogênico miogenina ficou em torno de $93,8{ }^{\circ} \mathrm{C}$. Para a confirmação dos resultados as amostras foram submetidas à eletroforese em gel de agarose 1\% (Figura 2) onde pode ser verificada a melhor condição de amplificação.

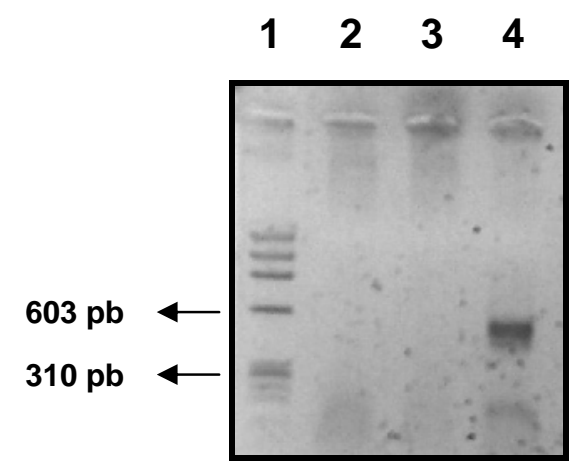

Figura 2 - Fotografia de gel de agarose 1\% para visualização da amostras amplificadas em reação de PCR em tempo real para o fator miogênico miogenina. A canaleta 1 - corresponde ao marcador de peso molecular $\phi \times 174$ (Invitrogen); 2 - concentração de $\mathrm{MgCl}_{2}$ de 1,5 mM; 3 - concentração de $\mathrm{MgCl}_{2}$ de $2 \mathrm{mM}$ e 4 - concentração de $\mathrm{MgCl}_{2}$ de $3 \mathrm{mM}$ 
Anexo D

Otimização da reação de PCR para o gene miostatina

Para o gene da miostatina foram feitos alguns testes e chegou-se a uma condição otimizada de amplificação. A temperatura de anelamento foi ajustada para $62^{\circ} \mathrm{C}$ e concentração de $\mathrm{MgCl}_{2}$ de $2 \mathrm{mM}$. Os resultados da otimização das condições de amplificação por PCR em tempo real podem ser visualizados nas Figuras 1,2 e 3.

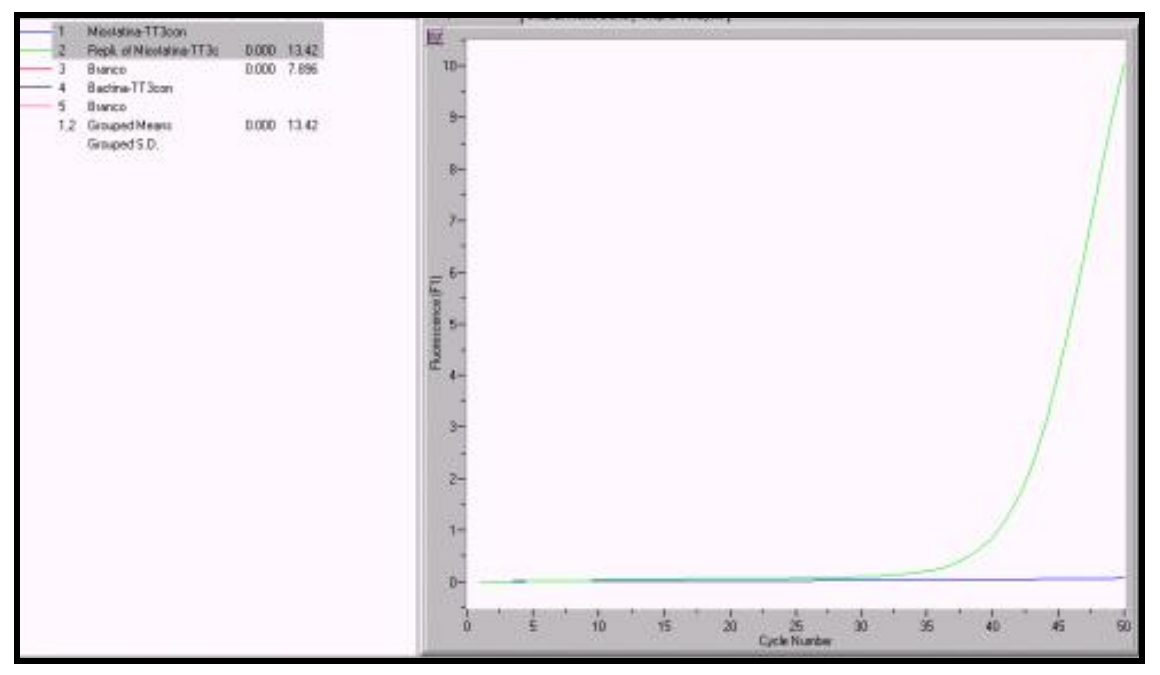

Figura 1 - Resultado da amplificação por PCR em tempo real para o gene miostatina

Pode-se observar a amplificação do gene miostatina a partir do ciclo 35. 


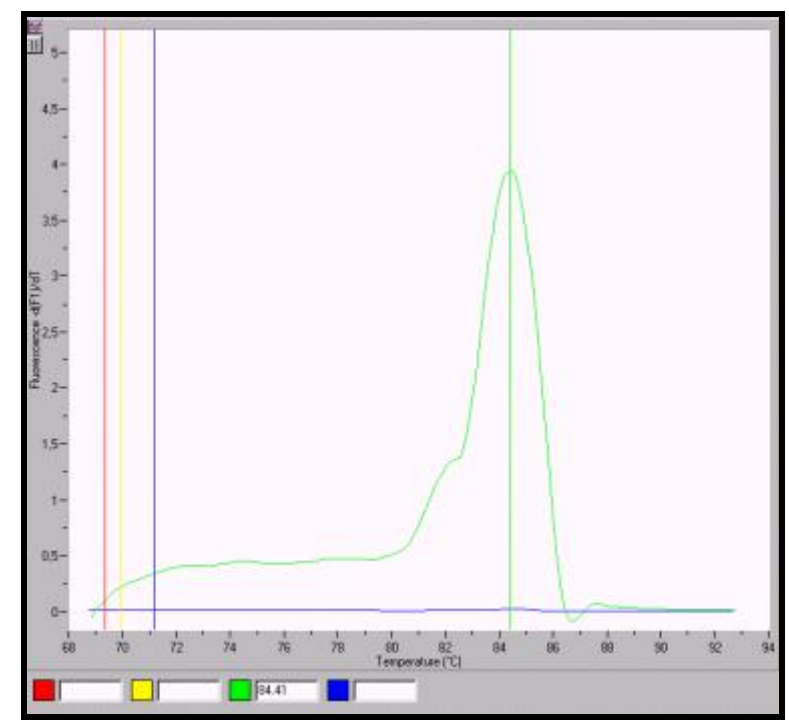

Figura 2 - Curva de melting do produto amplificado para o gene miostatina

A temperatura de melting para o produto amplificado para o gene da miostatina foi de $84,4^{\circ} \mathrm{C}$. Além disso, não foram constatadas amplificações inespecíficas e nem dímeros de primers. Para a confirmação dos resultados as amostras foram submetidas à eletroforese em gel de agarose 1\% (Figura 3).

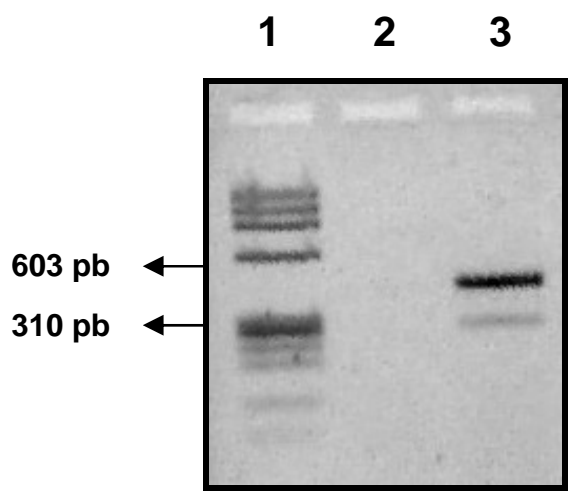

Figura 3 - Fotografia de gel de agarose 1\% para visualização da amostras amplificadas em reação de PCR em tempo real para o gene da miostatina. A canaleta 1 - corresponde ao marcador de peso molecular $\phi$ X 174 (Invitrogen); 2 e 3 - concentração de $\mathrm{MgCl}_{2}$ de 2 $\mathrm{mM}$ 


\section{Anexo E}

\section{Otimização da reação de PCR para os genes $\beta$-actina e Pax-3}

Para o gene Pax-3 também foram feitos testes e chegou-se a uma condição otimizada. A temperatura de anelamento permaneceu em $55{ }^{\circ} \mathrm{C}$ (condição otimizada em termociclador convencional). Foram ajustados os parâmetros de amplificação em tempo real (tempo de desnaturação, anelamento e extensão, bem como ajuste da curva de melting). No mesmo experimento foi incluído o gene da $\beta$-actina juntamente com Pax-3 na mesma reação (Figuras 1 e 2).

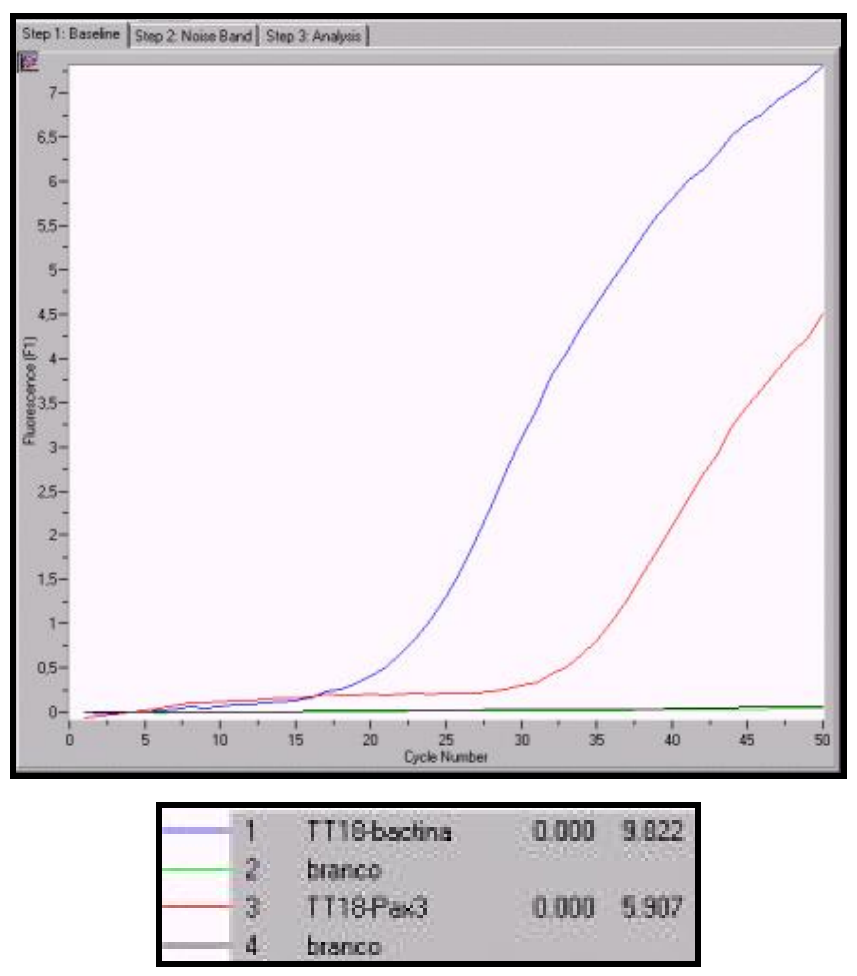

Figura 1 - Resultado da amplificação por PCR em tempo real para os genes $\beta$ actina e Pax-3 
Pode-se observar que os produtos amplificados foram detectados a partir dos ciclos 9 ( $\beta$-actina) e 5 (Pax-3).

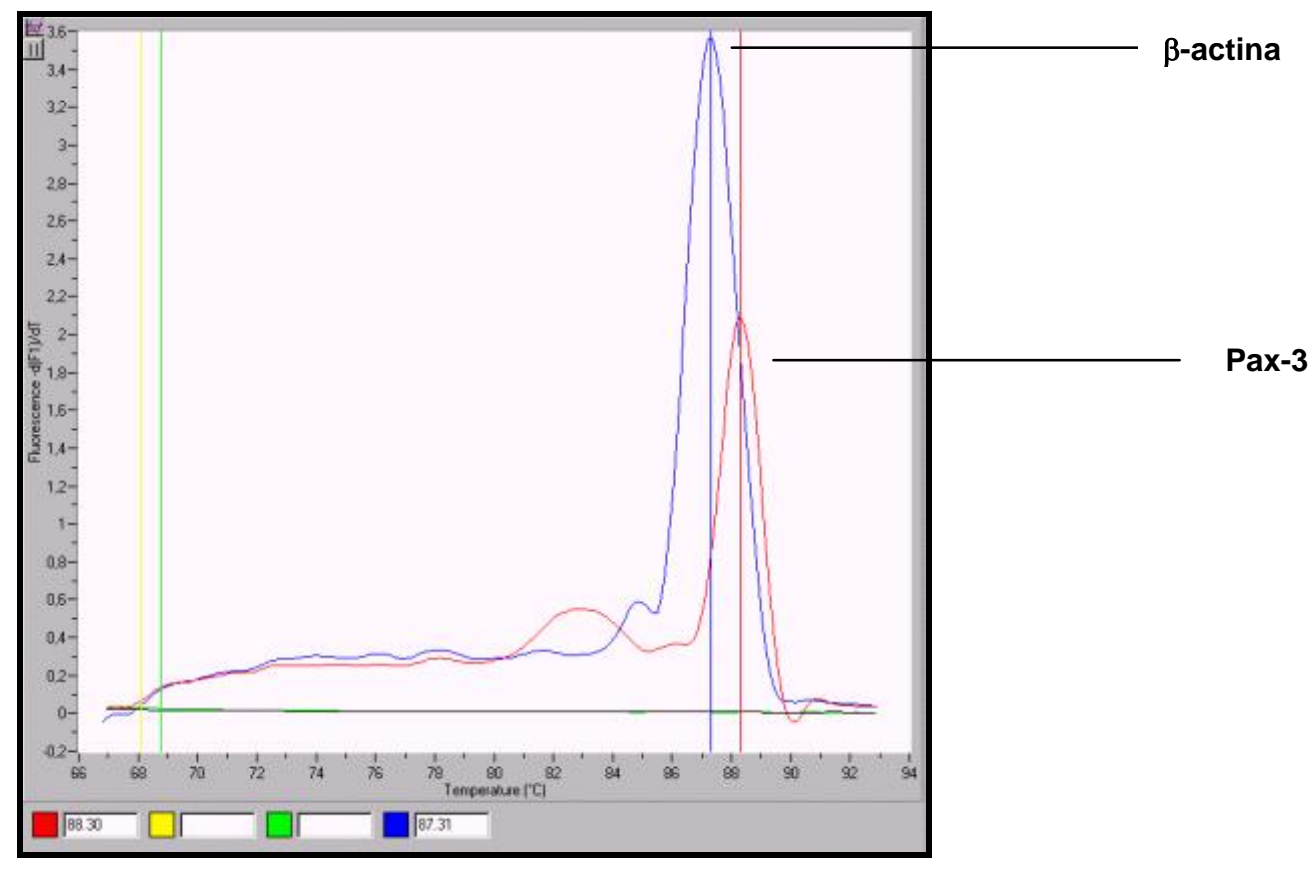

Figura 2 - Curvas de melting das amostras amplificadas para os genes $\beta$-actina e Pax-3

Pode-se observar que as temperaturas de melting foram de $87,3^{\circ} \mathrm{C}$ para $\beta$-actina e $88,3^{\circ} \mathrm{C}$ para Pax-3. Para a confirmação dos resultados as amostras foram submetidas à eletroforese em gel de agarose $1 \%$ (Figura 3 ) onde pode-se observar a amplificação de produtos específicos para os dois genes amplificados. 


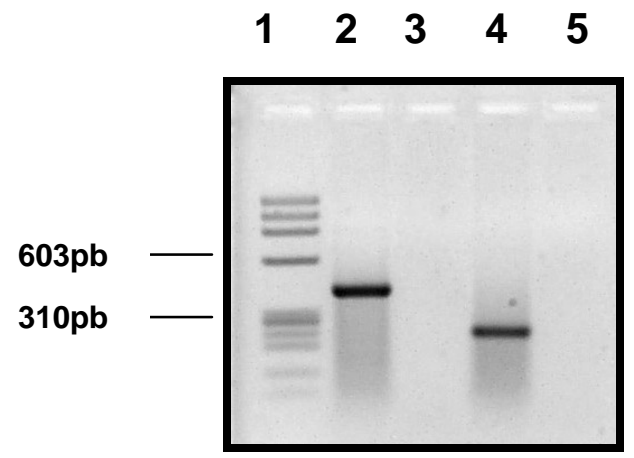

Figura 3 - Fotografia de gel de agarose 1\% para visualização da amostras amplificadas em reação de PCR em tempo real para $\beta$-actina e Pax3. A canaleta 1 - corresponde ao marcador de peso molecular $\phi X$ 174 (Invitrogen); 2 - produto amplificado para $\beta$-actina (409pb); 3 branco; 4- produto amplificado para Pax-3 (231pb); 5 - branco 


\section{REFERÊNCIAS BIBLIOGRÁFICAS}

ADAMS, M.D.; KELLEY, J.M.; GOCAYNE J.D.; DUBNICK, M.; POLYMEROPOULOS, M.H.; XIAO, H.; MERRIL, C.R.; WU, A.; VIDE, B.; MORENO, R.F. Complementary DNA Sequencing: Expressed Sequence Tags and Human Genome Project. Science, v.252, p.1651-1656, 1991.

ALTSCHUL, S.F.; GISH, W.; MILLER, W.; MYERS, E.W.; LIPMAN, D.J. Basic local alignment search tool. Journal of Molecular Biology, v.215, n.3, p.403-410, 1990.

ALVARES, L.E. Quantificação da expressão dos fatores miogênicos e de Pax-3 durante o desenvolvimento embrionário de aves. Rio Claro, 2001. 132p., Tese (Doutorado), Instituto de Biociências, Universidade Estadual Paulista "Júlio de Mesquita Filho".

ARBER, S.; HALDER, G.; CARONI, P. Muscle LIM protein, a novel essential regulator of myogenesis, promotes myogenic differentiation. Cell, v.79, n.2, p.221-231, 1994.

ARNOLD, H.H.; BRAUN, T. Genetics of muscle determination and development. Current Topics in Developmental Biology, v.48, p.129-164, 2000. 
ARNOLD, H.H; WINTER, B. Muscle differentiation: more complexity to the network of myogenic regulators. Current Opinion in Genetics and Development, v.8 n.5, p.539-544, 1998.

ABEF - Associação Brasileira dos Exportadores de Frango. Apresenta dados da produção brasileira de carne de frango. Disponível em <http://www.abef.com.br> Acesso em: 10 ago.2004.

BAILEY, P.; HOLOWACZ, T.; LASSAR, A.B. The origin of skeletal muscle stem cells in the embryo and the adult. Current opinion in Cell Biology, v.13, p.679-689, 2001.

BANDMAN, E.; ROSSER, B.W.C. Evolutionary significance of myosin heavy chain heterogeneity in birds. Microscopy Research and Technique, v.50, p.473-491, 2000.

BENSON, D.A.; BOGUSKI, M.S.; LIPMAN, D.J.; OSTELL, J.; FRANCIS OUELLETTE, B.F.; RAPP, B.A.; WHELLER, D.L. GenBank. Nucleic Acids Research, v.27, n.1, p.38-43, 1999.

BLACK, B.L.; OLSON, E.N. Transcriptional control of muscle development by myocyte enhancer factor 2 (MEF2) proteins. Annual Review of Cell Development Biology, v.14, p.167-196, 1998.

BOARDMAN, P.E.; SANZ-EZQUERRO, J.; OVERTON, I.M.; BURT, D.W.; BOSH, E.; FONG, W.T.; TICKLE, C.; BROWN, W.R.A.; WILSON, S.A. A comprehensive collection of chicken cDNAs. Current Biology, v.12, p.1965-1969, Nov., 2002. 
BRAND-SABERI, B.; CHRIST, B. Genetic and epigenetic control of muscle development in vertebrates. Cell Tissue and Research, v.296, p.199-212, 1999.

BROOKES, A.J. The essence of SNPs. Gene, v.234, p.177-186, 1999.

BUCKINKHAM, M. Skeletal muscle formation in vertebrates. Current Opinion in Genetics \& Development, v.11, p.440-448, 2001.

BUCKINGHAM, M.; BAJARD, L.; CHANG, T.; DAUBAS, P.; HADCHOUEL, J.; MEILHAC, S.; MONTARRAS, D.; ROCANCOURT, D.; RELAIX, F. The formation of skeletal muscle: from somite to limb. Journal of Anatomy, v.202, p.59-68, 2003.

BUMSTEAD, N.; YOUNG, R.R.; TREGASKES, C.; PALYGA, P.; DUNN, P.P. Linkage mapping and partial sequencing of 10 cDNA loci in the ckichen. Animal Genetics, v.25, n.5, p.337-341, Oct.,1994.

CHENG, T-C.; HANLEY, T.A.; MUDD, J.; MERLIE, J.P.; OLSON, E.N.; Mapping of myogenin transcription during embryogenesis using transgenes linked to the myogenin control region. The journal of cell biology, v.119, n.6, p.1649-1656, 1992.

CHOMCZYNSKI, P.; SACCHI, N. Single step method of RNA isolation by acid guanidinium thiocyanate-phenol-chloroform extraction. Analytical Biochemistry, v.162, p.156-159, 1987.

CHRIST, B.; ORDHAL, C.P. Early stages of chick somite development. Anatomy and Embryology, v.191, p.381-396, 1995. 
COUTINHO, L. L.; MORRIS, J.; MARKS, H. L.; BUHR, R.J.; IVARIE, R. Delayed somite formation in a quail line exhibiting myofiber hyperplasia is accompanied by delayed expression of myogenic regulatory factors and myosin heavy chain. Development, v.117, p.563-569, 1993.

DAUNCEY, M.J.; GILMOUR, R.S. Regulatory factors in the control of muscle development. Proceedings of the Nutrition Society, v.55, p.543-559, 1996.

DAVIS, R.L.; WEINTRAUB, H.; LASSAR, A.B. Expression of a single transfected cDNA converts fibroblasts to myoblasts. Cell, v.51, p.987-1000, 1987.

DAVOLI, R.; ZAMBONELLI, P.; BIGI, D. FONTANESI, L.; RUSSO, V. Analysis of expressed sequence tags of porcine skeletal muscle. Gene, v.233, p.181188, 1999.

EMERSON, C.P. Skeletal myogenesis: genetics and embryology to the fore. Current Opinion in Genetics and Development, v.3, p.265-274, 1993.

ENSEMBL. Chicken Genome Browser. Genome database from Sanger Institute. Disponível em: <http://www.ensembl.org/Gallus_gallus/> Acesso em: 23 jul 2004.

ESTEVE, P.; MORCILLO, J.; BOVOLENTA, P. Early and dynamic expression of cSfrp1 during chick embryo development. Mechanisms of Development, v.97, p.217-221, 2000.

EWING, B.; GREEN, P. Base-calling of automated sequencer traces using Phred. II. Error probabilities. Genome Research, v.8, p.186-194, 1998. 
FÜCHTBAUER, E-M. Inhibition of skeletal muscle development: less differentiation gives more muscle. In: BRAND-SABERI, B. (Ed.): Vertebrate myogenesis Results and problems in cell differentiation, Berlim: Springer-Verlag, 2002. p.143-161.

FUJII, J.; OTSU, K.; ZORZATO, F,; DE LEON, S.; KHANNA, V.K.; WEILER, J.E.; O'BRIEN, P.J.; MACLENNAN, D.H. Identification of a mutation in porcine ryanodine receptor associated with malignant hyperthermia. Science, v.253, p.448-451, 1991.

GABRIEL, J.E.; ALVES, H.J.; ALVARES, L.E.; SCHMIDT, G.S.; COUTINHO, L.L. In situ detection of transcripts of the myogenic factor MyoD in whole chicken embryos. Genetics and Molecular Biology, v.123, p.145-148, 2000.

GENE ONTOLOGY CONSORTIUM. Disponível em: <http://www.geneontology.org> Acesso em: 9 jan 2004.

GHetie, V.; ChItescu, S. T.; COtOFAN, V.; HALLEBRAND, A. Atlas de Anatomia de las Aves Domesticas. Zaragoza: Acribia, 1981. 294 p.

GILBERT, S.F. Developmental biology. $7^{\text {th }}$ edition. Sunderland: Sinauer Associates, 2003. 750p.

GINZINGER, D.G. Gene quantification using real-time quantitative PCR: An emerging technology hits the mainstream. Experimental Hematology, v.30, p.503-512, 2002. 
GIULIETTI, A.; OVERBERGH, L.; VALCKX, D.; DECALLONNE, B.; BOUILLON, R.; MATHIEU, C. An overview of real-time quantitative PCR: applications to cytokine gene expression. Methods, v.25, p.386-401, 2001.

GORDON, D.; ABAJIAN, C.; GREEN, P. Consed: a graphical tool for sequence finishing. Genome Research, v.8, p.195-202, 1998.

GUERNEC, A.; BERRI, C.; CHEVALIER, B.; WACRENIER-CERE, N.; LE BIHAN-DUVAL, E.; DUCLOS, M.J. Muscle development, insulin-like growth factor-I and myostatin mRNA levels in chickens selected for increased breast muscle yield. Growth Hormone \& IGF Research, v.13, p.8-18, 2003.

HALFTER, W.; DONG, S.; BALASUBRMANI, M. BIER, M.E. Temporary disruption of the retinal basal lamina and its effect on retinal histogenesis. Developmental Biology, v.238, n.1, p.79-96, Oct., 2001.

HAMBURGER, V.; HAMILTON, H.L. A series of normal stages in the development of the chick embryo. Journal of Morphology, v.88, p.49-92, 1951.

HANAHAN, D. In: DNA Cloning, Volume 1, 1985.

HAUSCHKA, S.D. The embryonic origin of muscle. In: ENGEL, A.G. Myology. New York: Mcgraw-Hill, 1994. cap.1, p.3-73.

HILL, D.P.; DAVIS, A.P.; RICHARDSON, J.E.; CORRADI, J.P.; RINGWALD, M.; EPPIG, J.T.; BLAKE, J.A. Strategies for biological annotation of mammalian systems: implementing gene ontologies in mouse genome informatics. Genomics, v.74, p.121-128, 2001. 
HUANG, X.; MADAN, A. Cap3: a DNA sequence assembly program. Genome Research, v.9, p.868-877, 1999.

Interpro EMBL-EBI. European Bioinformatics Institute. Disponível em: <http://www.ebi.ac.uk/InterProScan/> Acesso em: 21 jul 2004.

JIA, L.; YOUNG, M. F.; POWELL, J.; YANG, L.; HO, N.C.; HOTCHKISS, R.; ROBEY, P.G.; FRANCOMANO, C.A. Gene expression profile of human bone marrow stromal cells: high-throughput expressed sequence tag sequencing analysis. Genomics, v.79, n.1, p.7-17, 2002.

KALCHEIM, C.; CINNAMON, Y.; KAHANE, N. Myotome formation: a multistage process. Cell and Tissue Research, v.296, p.161-173, 1999.

KOCAMIS, H.; KIRKPATRICK-KELLER, D.C.; RICHTER, J.; KILLEFER, J. The ontogeny of myostatin, follistatin and activin-B mRNA expression during chicken embryonic development. Growth, Development and Aging, v.63, n.4, p.143-150, 1999.

KONG, Y.; FLICK, M.J.; KUDLA, A.J.; KONIECZNY, S.F. Muscle LIM protein promotes myogenesis by enhancing the activity of MyoD. Molecular and Cellular Biology, v.17, n.8, p.4750-4760, 1997.

LI, S.; LIU, N.; ZADWORNY, D.; KUHNLEIN, U. Genetic variability in white leghorns reveled by chicken liver expressed sequence tags. Poultry Science, v.77, n.1, p.134-139, 1998.

LIVAK, K. J.; SCHMITTGEN, T. D. Analysis of relative gene expression data using real-time quantitative $P C R$ and the $2^{-\triangle \Delta C} T$ method. Methods, v.25, p.402-408, 2001. 
LUDOLPH, D.C.; KONIECZNY, S.F. Transcription factor families: muscling in on the myogenic program. FASEB Journal, v.9, n.12, p.1595-1604, 1995.

MAROTO, M.; RESHEF, R.; MÜSNSTERBERG, A.E.; KOESTER, S.; GOULDING, M.; LASSAR, A.B. Ectopic Pax-3 activates MyoD and Myf-5 expression in embryonic mesoderm and neural tissue. Cell, v.89, n.4, p.139148, 1997.

McPHERRON, A.C.; LAWLER, A.M.; LEE, S-J. Regulation of skeletal muscle mass in mice by a new TGF- $\beta$ superfamily member. Nature, v.387, p.83-90, 1997.

MILLER, J.B.; CROW, M.T.; STOCKDALE, F.E. Slow and fast myosin heavy chain content defines three types of myotubes in early muscle cell cultures. The Journal of Cell Biology, v.101, p.1643-1650, 1985.

MINETTI, C.; SOTGIA, F.; BRUNO, C.; SCARTEZZINI, P.; BRODA, P.; BADO, M.; MASETTI, E.; MAZZOCCO, M.; EGEO, A.; DONATI, M.A.; VOLONTE, D.; GALBIATI, F.; CORDONE, G.; BRICARELLI, F.D.; LISANTI, M.P.; ZARA, F. Mutations in the caveolin-3 gene cause autosomal dominant limb-girdle muscular dystrophy. Nature Genetics, v.18, n.4, p.365-368, 1998.

OKUBO, K.; HORI, N.; MATOBA, R.; NIIYAMA, T.; FUKUSHIMA, A.; KOJIMA, Y.; MATSUBARA, K. Large-scale cDNA sequencing for analysis of quantitative and qualitative aspects of gene expression. Nature Genetics, v.2, p.173-179, 1992.

ORDAHL, C.P.; LE DOUARIN, N.M. Two myogenic lineages in the development somite. Development, v.14, p.339-352, 1992. 
OTTINI, L.; MARZIALI, G.; CONTI, A.; CHARLESWORTH, A.; SORRENTINO, V. $\alpha$ and $\beta$ isoforms of ryanodine receptor from chicken skeletal muscle are the homologues of mammalian RyR1 and RyR3. Biochemical Journal, v.315, p.207-216, 1996.

PATEL, K.; CHRIST, B.; STOCKDALE, F.E. Control of muscles size during embryonic, fetal, and adult life. In: BRAND-SABERI, B. (Ed.): Vertebrate myogenesis Results and problems in cell differentiation, Berlim: Springer-Verlag, 2002. p.163-186.

PERRY, R.L.S.; RUDNICK, M.A. Molecular mechanisms regulating myogenic determination and differentiation. Frontiers in Biosciences, v.5, p.750-767, Sep., 2000.

PICARD, B.; LEFAUCHEUR, L.; BERRI, C.; DUCLOS, M. Muscle fibre ontogenesis in farm animal species. Reproduction, Nutrition and Development, v. 42, p. 415-431, 2002.

PROSDOCIMI, F.; CERQUEIRA, G.C.; BINNEC, E.; SILVA, A.; REIS, A. N.; JUNQUEIRA, A.C.M.; SANTOS, A.C.F.; NHANI JÚNIOR, A.; WUST, C.I.; FILHO, F.C.; KESSEDJIAN, J.L.; PETRETSKI, J.H.; CAMARGO, L.P.; FERREIRA, R.G.M.; LIMA, R.P.; PEREIRA, R.M.; JARDIM, S.; SAMPAIO, V.S.; FOLGUERAS-FLATSCHART, A.V. Bioinformática: Manual do usuário. Biotecnologia Ciência e Desenvolvimento, n.29, p.12-25, 2002.

PURI, P.L.; SARTORELLI, V. Regulation of muscle regulatory factors by DNAbinding, interacting proteins, and post-transcriptional modifications. Journal of cellular Physiology, v.185, p.155-173, 2000.

RAWLS, A.; OLSON, E.N. MyoD meets its maker. Cell, v. 89, n.4, p.5-8, 1997. 
RUDNICKI, M.A.; JAENISCH, R. The MyoD family of transcription factors and skeletal myogenesis. Bioessays, v.17, p.203-209, 1995.

SABOURIN, L.A.; RUDNICKI, M.A. The molecular regulation of myogenesis. Clinical Genetics, v.57, p.16-25, 2000.

SASSON, D.A. Myogenic regulatory factors: dissecting their role and regulation during vertebrate embryogenesis. Developmental Biology, v.156, p.11-23, 1993.

SCHEUERMANN, G.N.; BILGILI, S.F.; TUZUN, S.; MULVANEY, D.R. Comparison of chicken genotypes: myofiber number in pectoralis muscle and myostatin ontogeny. Poultry Science, v.83, p.1404-1412, 2004.

SCHIAFFINO, S.; REGGIANI, C. Molecular diversity of myofibrillar proteins: gene regulation and functional significance. Physiological Reviews, v.76, n.2, p.371-423, 1996.

SMITH, E.J.; SHI, L.; SMITH, G. Expressed sequence tags for chicken genome from a normalized 10-day-old White Legorn whole embryo cDNA library: 3. DNA sequence analysis of genetic variation in commercial chicken pupulations. Genome, v.45, p.261-267, 2002.

SMITH, E.J.; SHI, L.; PREVOST, L.; DRUMMOND, P.; RAMLAL, S.; SMITH, G.; PIERCE, K.; FOSTER, J. Expressed sequence tags for chicken genome from a normalized 10-day-old White Legorn whole embryo cDNA library: 2. Comparative DNA Sequence analysis of guinea fowl, quail, and turkey genomes. Poultry Science, v.80, p.1263-1272, 2001(a). 
SMITH, E.J.; SHI, L.; DRUMMOND, P.; RODRIGUEZ, L.; HAMILTON, R.; RAMLAL, S.; SMITH, G.; PIERCE, K; FOSTER, J. Expressed Sequence Tags for the chicken genome from a normalized 10-day-old white leghorn whole embryo cDNA library: 1. DNA sequence characterization and linkage analysis. The Journal of Heredity, v.92, n.1, p.1-8, 2001(b).

SMITH, E.; SHI, L.; DRUMMOND, P.; RODRIGUEZ, L.; HAMILTON, R.; POWELL, E.; NAHASHON, S.; RAMLAL, S.; SMITH, G.; FOSTER, J. Development and characterization of expressed sequence tags for the turkey (Meleagris gallopavo) genome and comparative sequence analysis with other birds. Animal Genetics, v.31, n.1, p.62-67, 2000.

STOCKDALE, F.E.; NIKOVITS, J.R.; CHRIST, B. Molecular and cellular biology of avian somite development. Developmental Dynamics, v. 219, p.304321, 2000.

TAJBAKHSH, S.; ROCANCOURT, D.; COSSU, G.; BUCKINGHAM, M. Redefining the genetic hierarchies controlling skeletal myogenesis: Pax-3 and myf-5 act upstream of MyoD. Cell, v.89, p.127-138, 1997.

TIDYMAN, W.E.; MOORE, L.A.; BANDMAN, E. Expression of fast myosin heavy chain transcripts in developing and dystrophic chicken skeletal muscle. Developmental dynamics, v.208, p.491-504, 1997.

TIGR/EGAD. The Institute for Genomic Research. Disponível em: <http://www.tigr.org/egad/> Acesso em: 14 dez 2001. 
VALDEZ, M.R.; RICHARDSON, J.A.; KLEIN, W.H.; OLSON, E.N. Failure of Myf5 to support myogenic differentiation without myogenin, MyoD, and MRF4. Developmental Biology v.219, n.2, p.287-298, 2000.

VIGNAL, A.; MILAN, D.; SAN CRISTOBAL, M.; EGGEN, A. A review on SNP and other types of molecular markers and their use in animal genetics. Genetics Selection Evolution, v.34, n.3, p.275-305, 2002.

WEINTRAUB, H.; DWARKI, V.J.; VERMA, I.; DAVIS, R.; HOLLENBERG, S.; SNIDER, L.; LASSAR, A.; TAPSCOTT, S.J. Muscle-especific transcriptional activation by MyoD. Genes and Development, v.5, n.8, p.1377-1386, 1991.

WIGMORE, P.M.; EVANS, D.J.R. Molecular and cellular mechanisms involved in the generation of fiber diversity during myogenesis. International Review of Cytology, v.216, p.175-232, 2002.

XIE, H.; WASSERMAN, A.; LEVINE, Z.; NOVIK, A.; GREBINSKIY, V.; SHOSHAN, A.; MINTZ, L. Large-scale protein annotation trhough gene ontology. Genome Research, v.12, p.785-794, 2002. 